Please cite this paper as:

Chaloff, J. (2016), "The Impact of EU Directives on the labour migration framework in EU countries", OECD Social, Employment and Migration Working Papers, No. 180, OECD Publishing, Paris. http://dx.doi.org/10.1787/5jlwxbzpwh33-en

OECD Social, Employment and Migration Working Papers No. 180

\title{
The Impact of EU Directives on the labour migration framework in EU countries
}

Jonathan Chaloff

JEL Classification: F22, F53, F55, K37

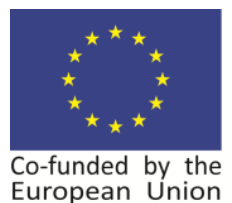


Organisation de Coopération et de Développement Économiques

Organisation for Economic Co-operation and Development

03-Jun-2016

DIRECTORATE FOR EMPLOYMENT, LABOUR AND SOCIAL AFFAIRS

English - Or. English

EMPLOYMENT, LABOUR AND SOCIAL AFFAIRS COMMITTEE

Cancels \& replaces the same document of 04 May 2016

The Impact of EU Directives on the labour migration framework in EU countries

Jonathan Chaloff (OECD)

JEL Classification:

F22, F53, F55, K37

This paper is part of the joint project between the Directorate General for Migration and Home Affairs of the European Commission and the OECD's Directorate for Employment, Labour and Social Affairs on "Review of Labour Migration Policy in Europe”.

This document has been produced with the financial assistance of the European Union. The views expressed herein can in no way be taken to reflect the official opinion of the European Union.

Grant: HOME/2013/EIFX/CA/002 / 30-CE-0615920/00-38 (DI130895)

This paper is a revised version of an earlier paper (DELSA/ELSA/MI(2015)3) presented and discussed at the OECD Working Party on Migration in June 2015.

Authorised for publication by Stefano Scarpetta, Director, Directorate for Employment, Labour and Social Affairs, OECD.

www.oecd.org/els/workingpapers

JT03397308

Complete document available on OLIS in its original format

This document and any map included herein are without prejudice to the status of or sovereignty over any territory, to the delimitation of international frontiers and boundaries and to the name of any territory, city or area. 


\title{
DIRECTORATE FOR EMPLOYMENT, LABOUR AND SOCIAL AFFAIRS
}

\author{
www.oecd.org/els
}

\section{OECD SOCIAL, EMPLOYMENT AND MIGRATION WORKING PAPERS}

\author{
www.oecd.org/els/workingpapers
}

OECD Working Papers should not be reported as representing the official views of the OECD nor of its member countries nor of the members of the European Union. The opinions expressed and arguments employed are those of the author(s).

Working Papers describe preliminary results or research in progress by the author(s) and are published to stimulate discussion on a broad range of issues on which the OECD works. Comments on Working Papers are welcomed, and may be sent to the Directorate for Employment, Labour and Social Affairs OECD, 2 rue André-Pascal, 75775 Paris Cedex 16, France.

This series is designed to make available to a wider readership selected labour market, social policy and migration studies prepared for use within the OECD. Authorship is usually collective, but principal writers are named. The papers are generally available only in their original language - English or French with a summary in the other.

This document and any map included herein are without prejudice to the status of or sovereignty over any territory, to the delimitation of international frontiers and boundaries and to the name of any territory, city or area.

The statistical data for Israel are supplied by and under the responsibility of the relevant Israeli authorities. The use of such data by the OECD is without prejudice to the status of the Golan Heights, East Jerusalem and Israeli settlements in the West Bank under the terms of international law.

\section{Applications for permission to reproduce or translate all or part of this material should be made to:}

\author{
Head of Publications Service \\ OECD \\ 2, rue André-Pascal \\ 75775 Paris, CEDEX 16 \\ France
}

\section{Copyright OECD 2016}


DELSA/ELSA/WD/SEM(2016)6

\section{ACKNOWLEDGEMENTS}

The author would like to acknowledge useful comments from Jan Saver (European Commission), Kees Groenendijk (University of Nijmegen), Jean-Yves Carlier (Université Catholique de Louvain) and delegates of the OECD Working Party on Migration for comments on this paper, as well as Marianne Gierow and Jongmi Lee for their assistance. 


\begin{abstract}
This paper is part of the joint project between the Directorate General for Migration and Home Affairs of the European Commission and the OECD's Directorate for Employment, Labour and Social Affairs on "Review of Labour Migration Policy in Europe".

This document has been produced with the financial assistance of the European Union. The views expressed herein can in no way be taken to reflect the official opinion of the European Union.

Grant: HOME/2013/EIFX/CA/002 / 30-CE-0615920/00-38 (DI130895).

This paper is a revised version of an earlier paper (DELSA/ELSA/MI(2015)3) presented and discussed at the OECD Working Party on Migration in June 2015.

The paper examines the mechanisms for labour migration management across individual European countries. Distinguishing between high- and low-skilled workers, it investigates the policies aiming at attracting and retaining qualified migrants. It finds that in EU countries there are several different forms of barriers to labour migration, each of which is affected differently by EU legislation. It then specifically focuses on the Student, Researchers and EU Blue Card Directives, studying their effects on the real policy framework in the EU countries affected, in terms of approach. It finds that the first two directives have had a modest impact on the legislative framework, which was largely aligned with the Directive prior to transposition in many cases. The Blue Card scheme is compared in detail with national schemes, in terms of the key parameters of the Directive (criteria, processing standards, benefits, etc.).

The paper examines the use of a salary threshold and its different effect according to the country in which it is applied. The paper concludes by examining the impact of these directives on recruitment opportunities, attractiveness and levelling the playing field among EU countries. It explores some options for adjusting the policies in the future.
\end{abstract}




\title{
TABLE OF CONTENTS
}

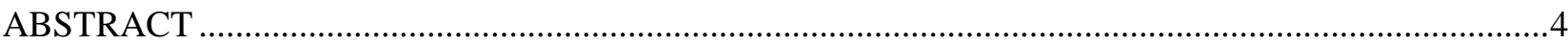

THE ROLE OF EMPLOYERS AND EMPLOYER ENGAGEMENT IN LABOUR MIGRATION FROM

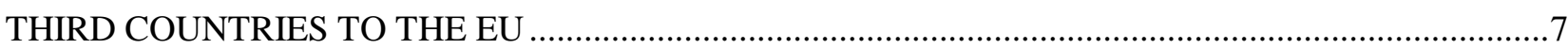

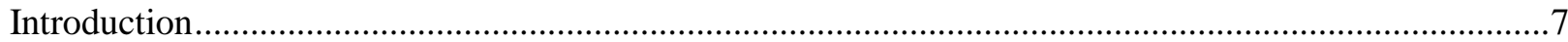

I. THE FRAMEWORK FOR LABOUR MIGRATION IN EUROPEAN UNION COUNTRIES .................8

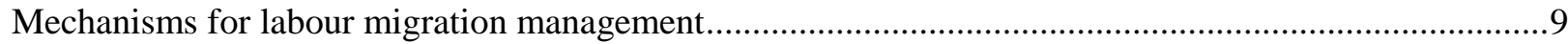

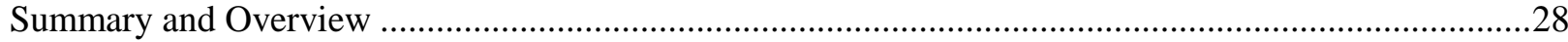

II. THE IMPACT OF EU DIRECTIVES ON THE LABOUR MIGRATION FRAMEWORK IN EU

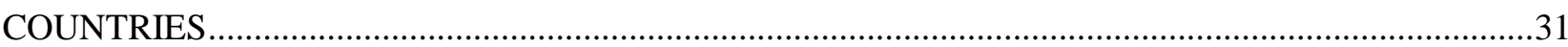

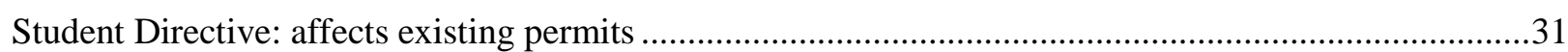

The Researcher Directive: a new fast-track permit in many countries ................................................34

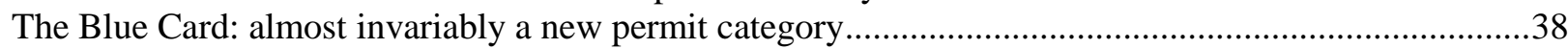

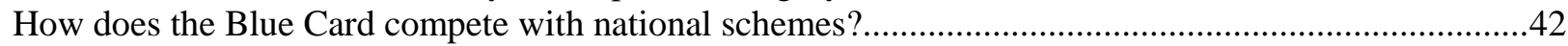

Have these changes opened up new opportunities to recruit foreign workers? ......................................56

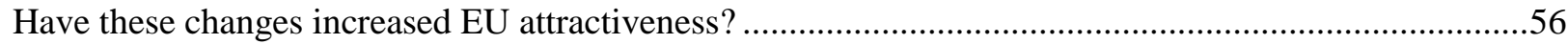

Have these changes levelled the playing field between third country nationals with work rights and EU

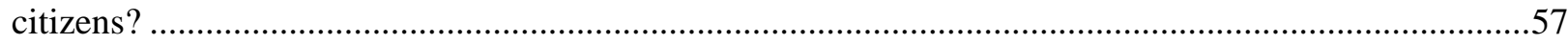

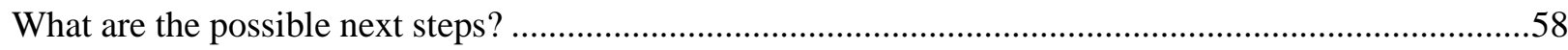

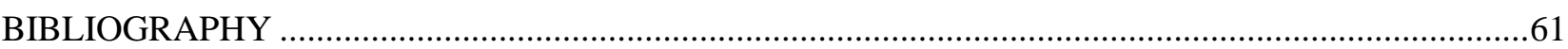

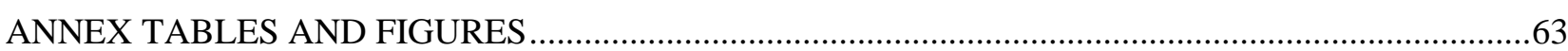

\section{Tables}

Table 1. The barriers to labour migration in selected EU countries ...............................................29

Table 2. The mean salary is very different according to the reference values used ............................45

Table 3. Labour Market Tests applying to national schemes and EU Blue Cards .............................50

Table 4. Duration of first permits, maximum ............................................................................52

Table 5. Simulation of the effect of different salary thresholds on the restrictiveness of the Blue Card

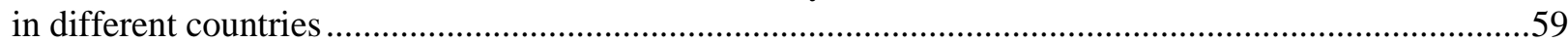

Table A.1. Labour market test processes in EU/EEA countries ......................................................63

Table A.2. Overview of main features of labour migration policy ……............................................ 70

Table A.3. Examples of Qualification Requirements under Blue Card schemes .............................72

Table A.4. Labour market mobility for EU Blue Card holders .......................................................75 


\section{Figures}

Figure 1. Labour migration rates vary widely among EU countries..............................................

Figure 2. Salary clustering is common when a salary threshold is imposed.....................................18

Figure 3. Differences in average salaries mean widely divergent salary requirements for highly qualified work permits in Europe ........................................................................................... 19

Figure 4. Salary thresholds are used for permits in a number of European countries..........................20

Figure 5. Countries without Blue Cards have lower salary thresholds for work permits than the Blue

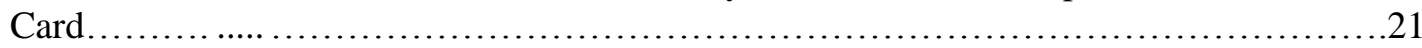

Figure 6. Most EU countries grant right to work to international students, although hours vary .........23

Figure 7. Many EU countries don't allow students to extend their permit beyond graduation to search

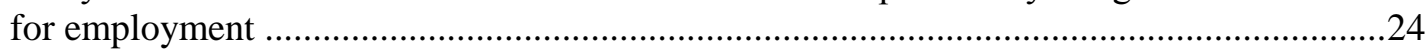

Figure 8. The Researcher permit appears associated with higher inflows in the Netherlands..............38

Figure 9. The distribution of earnings is not standard across EU countries........................................46

Figure 10. Only a small fraction of the total employed population earns more than the Blue Card threshold...................................................................47

Figure 11. The Blue Card threshold is far less restrictive for higher-educated workers....................48

Figure 12. It is much harder for young educated people to meet Blue Card thresholds ....................48

Figure 13. It is much easier to qualify for shortage list occupations ............................................49

Figure A.1. Salary distribution in selected EU countries, tertiary educated full-time employees .........77

Figure A.2. Salary distribution in non-Blue Card EU countries, tertiary educated full-time

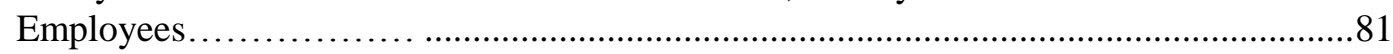

Figure A.3. Salary distribution in selected EU countries, tertiary educated full-time employees age

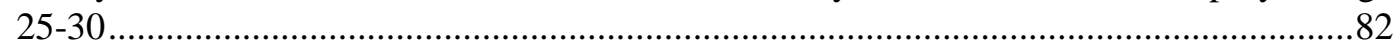

Figure A.4. Salary distribution in selected EU countries, tertiary educated full-time employees age

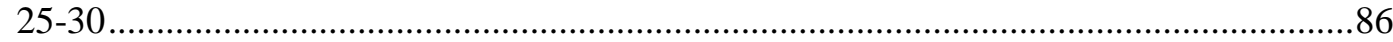

\section{Boxes}

Box 1. Using the EU SILC to determine salary distributions . .46 
DELSA/ELSA/WD/SEM(2016)6

\section{THE ROLE OF EMPLOYERS AND EMPLOYER ENGAGEMENT IN LABOUR MIGRATION FROM THIRD COUNTRIES TO THE EU}

\section{Introduction}

1. Historically, each EU country has set its own economic migration priorities and policies, and these have evolved separately to respond to the political economy and circumstances in each country. While economic migration comprises employees, job-seekers, entrepreneurs and investors, most policies are devoted to the labour migration, that is, migration for employment.

2. The EU unites countries with very disparate migration histories. Yet provisions for labour migration exist in all EU countries, in order to meet labour demand which cannot be effectively and efficiently met with local labour. The basic questions of labour migration policy is who to admit, how many to admit, and for what jobs. Different answers are given in each country, and these responses change over time. Beyond the basic question of admission, there is also a question of what rights labour migrants receive and acquire.

3. This paper examines how labour migration is managed in individual EU countries, in terms of the approach taken and the instruments used. In contrast to internal evaluations (see e.g., the Impact Assessment for the Blue Card, EC, 2007), the objective of this document is to examine how the different policy mechanisms translate into effective barriers or facilitations for migrants in EU countries, distinguishing between skilled and less skilled where relevant, and how these have evolved in practice. The information in this paper draws on questionnaires collected by the OECD Secretariat specifically looking at these issues in 2014 and 2015, and on input from national experts.

4. As this paper focuses on labour migration, other categories of third-country national with labour market access (family members, long-term residents, refugees, etc.) will not be directly considered, as their admission is not contingent on labour migration policy. This paper focuses on the Student, Researchers and EU Blue Card Directive, which have been transposed for enough time to permit an evaluation.

5. The first section looks at the mechanisms for labour migration management in Europe. It presents the different forms of definition of skilled and qualified migrants, and examines the policies in place to attract and retain skilled migrants. After covering migration channels which complement labour migration, it concludes with a summary of individual country approaches and broad comparisons.

5. The second section of the paper focuses specifically on the implementation of the Student, Researchers and EU Blue Card directive and their effects on the real policy framework in the EU countries affected, in terms of approach. The Blue Card is then compared with national schemes. The section concludes by examining the effects of these changes on recruitment opportunities, attractiveness and levelling the playing field among EU countries, and identifies possible further steps to achieve the goals of the Directives. 


\section{THE FRAMEWORK FOR LABOUR MIGRATION IN EUROPEAN UNION COUNTRIES}

6. The weight of labour migration relative to population varies widely across EU countries. In 20112012, the average for EU OECD countries was about one permanent-type labour migrant per thousand inhabitants, slightly above the OECD average (Figure 1). However, this conceals a wide variation among EU OECD countries. The countries admitting a higher inflow of labour migrants relative to population were Spain, the United Kingdom, Denmark and Italy. ${ }^{1}$

Figure 1. Labour migration rates vary widely among EU countries

Permanent immigration for work (entry or of status change), selected OECD countries, 2011-2012, per thousand inhabitants. Excludes mobility (intra-EEA migration).

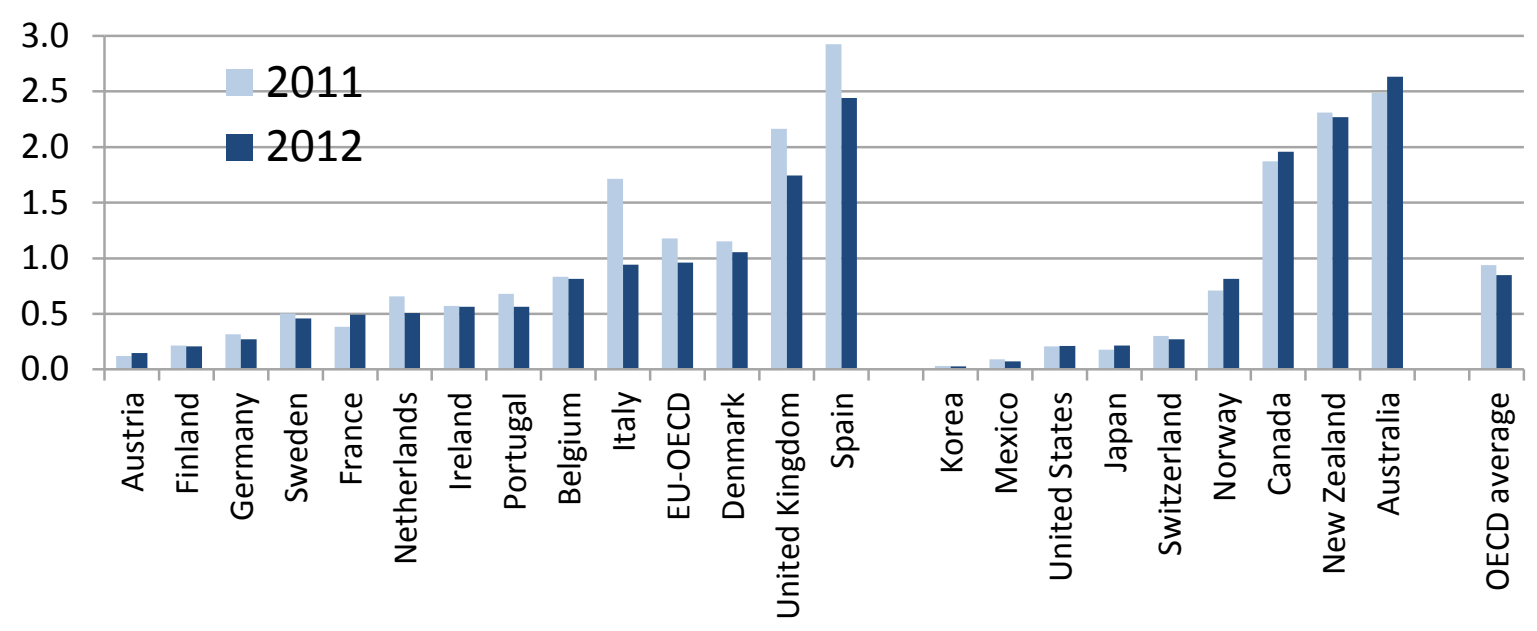

Source: OECD International Migration Database. Note: excludes some EU OECD countries, although these mostly have very low labour migration flows (e.g., Poland, Hungary, Czech Republic, Slovenia, Slovak Republic, Greece, Estonia), as do the non-OECD EU countries.

7. Labour migration to the United States is much lower, relative to population, than the EU OECD average. On the other hand, labour migration to Canada, New Zealand and Australia - all of which have selective labour migration programmes with little access to permanent migration for low-educated migrants or those in low-skill occupations - is much higher. This reflects these countries' commitment to ensuring that a substantial part of new entries to the skilled labour force stems from migration. Within the EEA, Switzerland has relatively low inflows of non-EEA permanent-type migration, while Norway has much higher levels. Both these non-EU countries have levels of free movement for employment which are much higher - at least ten times the level of third-country labour migration - and in Switzerland a substantial share of free movement is for skilled employment. Other OECD destinations have much lower levels of labour migration, including Japan and Korea.

$1 \quad$ A number of EU countries are not OECD members, and these countries have much lower labour migration flows than the EU and OECD average. 


\section{Mechanisms for labour migration management}

8. Labour migration policy is set at the national level through policy settings which determine eligibility for admission. In addition to education and occupational thresholds, these include numerical limits, shortage occupation lists, and labour market tests. With the exception of education and occupation requirements under the EU Blue Card directive, the settings of national mechanisms are unaffected by EU instruments and decided at the national level.

\section{Requirement of a job offer}

9. One of the foundations of the European model of labour migration is that economic migration to Europe has almost always historically required a qualifying job offer. It is thus the job, and not the individual worker, which is approved, although the worker must then meet the necessary criteria to fill the position. The characteristics of the job offer - the duration of the contract, the occupation for which the worker is recruited, the salary offered - become defining elements in regulating labour migration.

10. While the rule in Europe is that labour migrants cannot enter without a contract in hand, there have been some small experiments with job-seeker permits, and some remain in place. The principal examples are in the Netherlands, Denmark and the U.K. In Denmark, the Green Card introduced in 2009 allows candidates who meet education requirements to stay up to three years in the country. Even if they do not find employment under the salary-based or shortage list work permit criteria, they may renew their Green Card as long as they have worked an average of 10 hours a week in any job. More than a thousand such permits are authorised annually, although not all recipients take them up. In the Netherlands, issuance criteria for the job-search permit are very strict in terms of education, and the numbers are below 100 annually. Finally, in the UK, the Tier 1 for highly skilled migrants without a job offer, once based on the characteristics of the applicant, now relies on sponsorship, so that in practice recipients (subject to a quota) are already well-anchored in the country prior to receiving a permit under the programme. A short-lived but larger programme in Italy in 2000-2001 imposed no skill or education requirements and was oversubscribed before being eliminated. ${ }^{2}$

11. Outcomes under these programmes, in terms of the share who transition to skilled work permits, appear mixed from the scant evidence. What is clear is that many recipients do not end up qualifying for skilled work permits (see OECD 2014a for figures). This led Denmark, for example, to completely rework its system to narrow selection criteria and tighten requirements for extension (Wind and Adamo, 2015).

12. In the absence of such a job search visa, it is possible to arrive legally - on a tourist or visitor visa - and seek employment. Allowing in-country status change from tourist visas means that a sort of de facto job-search permit is in place. Most EU countries, however, do not allow in-country status changes to employment from tourist visas, and require the applicant to be recruited directly from abroad. Austria allows in-country status changes from visitors and tourists to workers, for example, while the Netherlands does not. In other countries, processing times may mean that the tourist visa expires before a work permit can be issued, forcing the applicant to return home. In Sweden, such changes are only allowed for jobs on a shortage occupation list. Spain only allows such changes in rare exceptions.

13. In addition to requiring a job offer, employers may also be subject to pre-approval requirements in order to sponsor a worker. The granting of sponsor status is an additional tool in regulating migration flows. In the United Kingdom, sponsorship is central to the point-based system through which much of labour migration is based. Compliance with its immigration system is reinforced by imposing requirements

$2 \quad$ No selection criteria were applied, although there was an annual quota of 15000 job-seekers sponsored by a resident in Italy to enter the country; about 11000 permits were issued. Sponsors were mostly recent immigrants bringing relatives and friends from their home countries (Caritas, 2002). 
on the employer. Similarly, the Dutch Knowledge Migrant Scheme requires the foreign national to be sponsored by an employer which must be a Dutch entity registered to participate in the program.

\section{Numerical limits}

14. Numerical limits can take various forms such as quotas, targets, ceilings, caps or "volumes of admission". The use of targets, as noted earlier, is related to demographic objectives; the only European example from recent years is the political objective set in the UK to reduce net migration, quite a different objective from the targets in Canada and Australia. This was not specifically a labour migration target, although labour and student migration, as the categories over which the most discretion can be exercised, were the main target of efforts to restrict migration.

15. Those different forms reflect different objectives. While quotas specify a pre-set allocation, a target sets a limit to be reached, and a ceiling or cap fix an upper bound not to be exceeded. The first two forms of numerical instrument aim at ensuring that the domestic labour market conditions are not too strongly distorted and the local employment is safeguarded. Numerical limits may play a role in limiting entries in two ways, by cutting off consideration of applications if the number of eligible applications exceeds the limit; and by indirectly discouraging applicants.

16. In practice, in most European countries, the political choice has not been to set numerical limits on skilled workers admitted, but rather to issue permits to all workers filling positions which are open. This is contrast to the limits imposed on labour migration by skilled workers in the main non-European OECD destinations, where limits apply to all categories. There are, in fact, no backlogs or waiting lists for skilled migrants in Europe. In settlement countries, even with economic migration targets well above the current migration levels in most European countries, backlogs of eligible applicants have formed. These backlogs presented at least two problems: priority candidates - those with jobs waiting for them, or in urgently needed occupations - were stuck in the queue; and administrations had to process all applications. The transition to a two-phase application process, with a pool of eligible candidates from which applicants are chosen and invited to apply, was implemented to overcome precisely these issues. The Expression of Interest in New Zealand, SkillSelect in Australia and ExpressEntry are all mechanisms to eliminate backlogs created by excess supply relative to targets (OECD, 2014a). The United States has a multi-year backlog of applicants for some of its employment-based permanent residence permits, and applies an annual limit to specialty workers (H-1B visas) which has been exhausted in its first week in recent years.

17. No such system is necessary in European countries where indeed skilled migrant programmes have rather failed to meet objectives in the rare instances in which numerical goals are stated. Germany's brief experiment in the mid-2000s with a permit for IT workers failed to attract the target numbers. Austria introduced a new set of permits in 2011 but failed to see incoming numbers rise as much as originally announced (OECD, 2014c). The United Kingdom introduced numerical limits together with stricter criteria and found - unexpectedly - that uptake was lower than the available permits in the first five years of application. ${ }^{3}$

18. Numerical limits are occasionally applied relative to enterprise size. Ireland selectively applies quotas to the number of intra-company transferees, which cannot exceed 5\% of the company's total Irish workforce.

3 The United Kingdom has set specific quotas for its different work permits. There is an annual limit of 1,000 endorsements for MBA graduates, 900 for graduates in other subjects, and 100 for UK Trade and Investment's elite global graduate entrepreneur scheme, while the Tier 1 Exceptional Talent category is limited to 1000 endorsements per year and the Tier 2 visa is capped at an annual limit of 20700. 


\section{Numerical limits in undifferentiated programmes}

19. Numerical limits are more frequent in programmes allowing labour migration for nonprofessional occupations, such as seasonal work, and where there are no skills or education criteria. Numerical limits, for example, are set in Portugal and Italy. Procedures vary. In Portugal the numbers are set annually since 2004 by the Professional Training Institute. The Portuguese Ministry of Labour first proposes an annual cap (contingente global) based on an analysis of vacancies, employment trends and expected interest in international recruitment. The proposed cap is submitted to the social partners before finalisation. In Italy the numerical limits are the principal means for regulating labour migration, and annual numbers excluding seasonal workers have ranged widely between zero and 170 thousand since their first introduction in 1998; demand in most years has exceeded the number of applications accepted. The consultation mechanism initially foreseen in the 1998 law has been reduced to a largely political decision, underlining the political difficulty in many countries of setting a limit. The blunt nature of numerical limits was clear as skilled workers, subject to the general limits, were often unable to enter within the limits. Certain sectors also failed to receive an adequate share of admissions; sector-based quotas were introduced during many years in order to ensure that employment went to construction, fisheries or domestic work, for example. In addition to a number of special clauses exempting certain occupations and employers, a separate executive quota was allotted in the mid to late 2000s. Since 2007, skilled workers and executives have also been exempt from these limits, as are the more recent recipients of the EU Blue Card.

20. In Spain, for the granting of both seasonal and regular work permits, the "collective management of contracts in the country of origin" is published every year by ministerial decree by the Secretariat General of Immigration and Emigration. It allows employers to recruit a number of workers in certain occupations. Similarly, the Austrian Federal Minister of Labour, Social Affairs and Consumer Protection additionally sets quotas for the sectors of tourism, agriculture and forestry, by way of regulation for the employment of seasonal workers and harvest helpers if the demand for such workers cannot be covered from the available workforce.

21. Greece reformed its "Volumes of Admission" system in 2014, to create a system for anticipating labour shortages in the next biennium. "Volumes of admission" are drawn up every year last quarter in every region and a Joint Ministerial Decision outlines the maximum number of residence permits for the purpose of employment that can be issued. The process involves local and national actors and, in light of the current employment situation, has produced numerical limits of zero. Nonetheless, a small amount of flexibility is built into the system as the volume of high-skilled migrants recruited through the EU Blue card can be raised up to $10 \%$ for unforeseen needs.

22. Numerical limits are one of the most visible elements of migration management and thus one of the most politically charged. They send a strong signal to the public that migration is under control, by providing a clear figure. This may explain why several EU countries set caps for work permits which are substantially higher than the actual number of work permits expected to be issued, based on historical trends. Until 2014, Hungary set a limit based on demands the previous year, which leaves ample room for increase, even though its actual numbers have been stable and far below the limit. The minister responsible for employment issues is entitled to determine an annual quota for the maximum number of third country national employees in the country. In 2011, this number was 52 000, 85000 in 2012, and 76000 in 2013. From 2014, the quota will be based on the annual monthly average number of the vacancies reported by the employers excluding public sector employment and vacancies for foreign workers. Barring a spike in demand, this limit will be far above the usual number of requests. Romania also uses a quota which contains reserves for highly skilled foreign workers separate from other local hires, as well as for intracompany transferees. These contingents are invariably above the total of actual entries - about twice as high overall in 2015. 
23. Ceilings or caps can also be benchmarked to the size of the labour market population to prevent a negative effect on the domestic labour market, while enabling to adjust to the needs of a specific industry or sector. Until 2013, Austria used a cap on the total number of work permits held by third-country nationals, set at $8 \%$ of the total labour supply. Estonia uses a benchmark for inflows based on the size of the population; like limits in other countries, it has never yet been reached. Limits can also be at the firm level. Bulgaria imposes a 10\% limit on the number of third-country nationals employed in firms, excluding those with residence rights unrelated to employment (e.g., long term residence, family reunification, refugee status, etc.).

24. Overall, European volumes of admission offer the flexibility of annual or exceptional adjustments, especially when they apply to recruitment for highly-qualified employment. Yet the numerical limits constitute an actual limit on high skilled migration only in a few rare cases (e.g., Greece). More often, they represent a limit for employment in less skilled occupations, where concern over protecting the domestic labour market from potential distortion is much greater.

\section{Occupation lists}

25. Shortage occupation lists play a key role in the selection process of new labour migrants in a number of European countries. These are generally shortage lists, and their determination and application are unaffected by EU instruments (although they may be applied, with some restrictions, in the framework of the EU Blue Card). Lists can be used to allow or facilitate migration through different means:

- for general eligibility for migration, to direct labour migrants towards certain occupations

- for exemptions to the labour market test or numerical limits, for occupations where there is less concern about affecting local workers or where shortages are evident

- to apply lower salary thresholds than would otherwise apply

26. In France, Germany, Spain, The Netherlands and the United Kingdom, the lists are restricted to jobs requiring specific skills, and grant a labour market test exemption. The British Migration Advisory Committee shortage list applies to the Tier 2 skilled worker employer-driven category. The applicant whose occupation is on the list is being granted enough points to be exempted from the Resident Labour Market Test and from wage and educational requirements. In Spain, employers are also exempted from a labour market test when they want to hire migrants that will take up positions in shortage, while the Swedish system allows in-country status-change to work permit for migrants whose occupation is on the shortage list.

27. The efficacy of these shortage lists depends largely on the extent to which the labour market test is an obstacle, in terms of rejection rates or in terms of time spent waiting for answers. Since the rejection rate for labour market tests - especially in occupations likely to be on a shortage list - is quite low (OECD, 2011), the main gain for shortage list occupations is to save the time by circumventing the labour market test.

28. Austria has a category of "skilled workers in shortage occupation", which includes professionals who have a job offer in an occupation with a lack of workforce. Permits (a Red-White-Red Card) under this category are issued if applicants score 50 of the 75 criteria points under "qualification", "work experience according to qualification", "language skills" and/or "age". The list is issued by the Federal Minister of Labour in consultation with the Federal Minister of Economics and reviewed annually (OECD, 2014c). 
29. In Germany, certain categories and shortage areas are exempted from public advertisement requirements under the local labour market test. Similarly, a LMT is not required in the Netherlands if the foreign national is to be employed as an intra-company transferee and is to receive an annual salary of at least 50000 euros. In Spain, no labour market test is applied for work permit applications for occupations included in the "Hard-to-fill jobs catalogue", reviewed quarterly.

30. In Belgium, a B work permit can be granted through a fast track procedure if the job of the future migrant is included on the national labour market list. Public employment agencies of each region draws the list for labour migration purposes from their general lists of "bottleneck" occupations (e.g. secretary, sales person), regardless of the sectors (e.g. healthcare sector) in which they feature and the list is then revised annually.

31. In some cases, the list excludes migrants from specific occupations rather than foster their recruitment in positions in shortages. The Irish policy defines "Ineligible Categories of Employment". Those apply to the two categories of occupations under the Irish General Employment Permit Scheme. For contracts paying an annual salary of EUR 30000 a year or more (excluding bonuses), the work permit is available for all occupations except those considered ineligible. For salary ranges under EUR 30000 a year, only a very limited number of occupations are considered. For the "Critical Skills" permit (formerly "Green Card"), with a salary ranges between EUR 30000 and EUR 60000 a year, the job offer needs to be on the High-Skilled Occupation List. Similarly, Portugal's legislation created an exclusion list of occupations which cannot be open for international recruitment under the temporary stay visa and work permit.

\section{Assessment of shortages}

32. The calculation methods for shortage lists vary widely across EU countries, and are evidencebased, although by no means exclusively based on algorithms (for a longer discussion, see Chaloff, 2014). Stakeholders are consulted, and there is opportunity for interest groups to influence the list.

33. The Migration Advisory Committee in the United Kingdom uses a dozen "top-down" indicators ${ }^{4}$ to identify evidence about skill shortages. Indicators include vacancy levels within employment and hardto-fill vacancies, price and wage signals, along with employment trends and change in vacancy duration and stocks. In addition to those top-down data on wage and employment, the MAC has implemented a bottom-up approach through the collection of evidence from Sector Skills Councils and other educational groups. Partial review of labour shortage lists is conducted by the Migration Advisory Committee every six months, while full review is done every two years.

34. As noted above, Ireland has provisions to exclude certain occupations from labour migration, while Portugal's Ministry of Labour, after setting the annual cap, may identify occupations where no international recruitment will be allowed. In practice, Portugal has never done so.

35. The Greek shortage occupation list relies on a Joint Ministerial Decision, which takes into account the opinion of the Economic and Social Committee, the opinion of the National Manpower Organization and a recommendation from the Regions of the country relating to existing labour needs for highly qualified personnel. These needs are determined by various criteria such as the interests of the national economy, the purposefulness of employment, available labour supply on behalf of Greek citizens, EU citizens and already legally residing third countries' citizens, by specialty, as well as unemployment rates by sector of employment.

4 Three employer-based indicators, three price-based indicators, four volume-based indicators and two indicators of imbalances. 
36. Spanish public employment authorities use regional unemployment and job vacancy data and consult the Tripartite Labour Commission on Immigration, which includes social partners, to draw up a list of potential shortage occupations at the regional level ("Catalogue of Hard-to-fill Positions"). A similar formula is used in France, relying on jobs for which the ratio of unemployment to vacancies is one or less for at least one year, although the list is not regularly updated.

37. The Swedish shortage occupational list is defined based on vacancy index of Public Employment Service, especially the occupational Barometer - based on average vacancy scales declared by 200 local employment offices, and is subject to annual review (OECD, 2011).

\section{Labour Market Tests}

38. The Labour Market Test (LMT) is, in principle, a critical tool to protect local employment, the goal for most European countries in reviewing applications for labour migration. The procedure varies across countries, but the concept is to ensure that jobs are offered domestically or that no appropriate local worker is available for the job. The labour market test is unaffected by EU legislation in the field of labour migration, and how it is established and applied can determine who enters European countries as an economic migrant.

39. The labour market test has been around for more than six decades in Europe and predates the existence of the common market. It was an integral part of the negotiations for intra-OEEC mobility starting in the late 1940s, and was part of the 1953 OEEC Council Decision ${ }^{5}$, which stated:

"Suitable labour shall be deemed not to be available within the country if no suitable applicant has been found within the period of one month, at the latest, after the employer has both notified the vacancy in question to the employment service or any other service recognised officially as competent in the matter, and has also made known his intention to apply for a permit to employ a foreign worker if suitable labour is not forthcoming within the country, always provided that the employer has taken such other steps as are customary in the case of the kind in question to try and fill the vacancy".

40. The key elements of a labour market test are already evident in this Decision: publication duration requirements, the possible involvement of the public employment service, the burden of proof and broader efforts to fill vacancies.

41. All EU countries use some form of labour market test when authorising certain labour migrants. A comparison of labour market tests in EEA countries is shown in Table A.1 in the Annex. For European countries participating in the European Employment Service (EURES), the LMT generally requires the job offer to be advertised through the national public employment service and, on request in most cases although also by initiative of the public employment service (PES), through the EURES Job Mobility Platform. The LMT may be designed to give priority to the unemployed (registered job-seekers) rather than all job seekers, and likewise may refer to the national labour market (including not only nationals but all EEA nationals and legally resident non-EEA nationals with work rights).

42. The duration of the mandatory advertising period is variable (see Table A.1), although in most countries, vacancies must be advertised for at least a few weeks. Sweden requires only 10 days advertisement with the PES and EURES. In Ireland, the offer must be listed in the FAS/EURES system for two weeks and advertised in national press for at least three days. In Hungary, the potential employer must advertise the job through the PES of the district where the business is located for 15 days. In Italy, after 20 days of the job being listed by the PES, the employer may request issuance of a work permit to recruit from 
abroad. Employers are required to contact the PES prior to applying at the One-Stop service, and the PES must inform both the employer and the One-Stop service of any candidates available. ${ }^{6}$ If candidates are proposed, the application is suspended until the employer confirms to the One-Stop service the intention to proceed. The process is shorter for seasonal work permit, though the employer still needs a positive opinion by the PES. The LMT is longer in the Netherlands, where the employer must conduct recruitment for a period of at least five weeks by advertising the position in standard recruitment channels, such as Dutch newspapers, professional or trade journals, or online job boards or through placement agencies. Portugal and Slovakia both have 30-day PES requirements.

43. The advertising requirements appear largely comparable among countries at first glance but conceal significant differences: some are nominal, while in others a burden of proof is imposed on the employer to justify hiring practices. Nominal listings are those in which authorisation is automatic once the advertising period has lapsed, as in Latvia and Sweden. In other countries, such as Spain, the PES can and do send candidates to employers, requiring the employer to justify refusing these candidates. Elsewhere, the PES may decide on the request based on its knowledge of the labour market, or by examining the list of unemployed. This is the case in Austria and Finland, as well as in the Belgian region of Wallonia. The Austrian LMT (Arbeitsmarktprïfung) must show that there is no Austrian worker or no non-Austrian worker (already in the Austrian labour market) registered with the PES available for the job.

44. How employers classify the vacancy is important when the PES looks at registered unemployed. An example is Romania, where jobs must be classified in detail, and registered unemployed are usually low skilled and unclassified. Since there is almost never a match between precisely defined vacancies and unclassified job-seekers, the PES finds no suitable candidates and the LMT is nominal. In Belgium (Brussels), the ratio of vacancies of job seekers is used, although the Belgian LMT only applies to low skilled workers, and exemptions apply. In Poland, the PES authorises the request after a week if there are no job seekers, but it can decide to send candidates to the employer. If the employer rejects candidates, it is up to the PES to decide whether to approve the request, although refusals can be appealed to the Ministry of Labour. In practice such refusals are extremely rare. Further, temporary workers from neighbouring countries are exempt.

45. The generally low rejection rate for labour market tests (OECD, 2013), especially for skilled workers, begs the question of why EU countries continue to use these tests. They play a clear safeguarding role, allowing discretionary attention to increase during times of labour market slack. They play a role for public opinion, allowing policy makers to assert that labour migrants only come for jobs which no local workers will fill. More importantly, they discourage employers from filing spurious and marginal requests for foreign workers, since employers know their requests will be reviewed. The onus is shifted to employers to demonstrate a need for the recruited worker. Finally, they ensure that the PES receives vacancy listings, boosting the market share of vacancies covered by the PES and improving their ability to reflect labour market conditions. ${ }^{7}$

6 Until 2013, this was part of the work permit application process through the One-Stop service, which sent the request to the PES.

7 In the case of large inflows, such as those seen in Italy in response to quota decrees, or the introduction of the Swedish system in 2008, the mandatory PES listing can increase the number of vacancies listed with the PES noticeably. If the requests are opportunistic - many Italian listings were for non-existent jobs by individual employers (OECD 2014d) - this can distort the ability of the PES to reflect actual labour market developments. 


\section{Towards more selective conditions for admission}

46. During the last decade, and especially since the onset of the crisis, European countries have been more selective in their labour immigration, to recruit only those who are perceived to bring the most benefits for the country. In most cases, this has meant targeting mostly high-skilled migrants.

47. Language and salary conditions have become more stringent in most countries. In the Netherlands, the High-Skilled Migrant Scheme was tightened to allow rejection of a residence permit if the salary of the migrant appears suspiciously high for the occupation. In the United Kingdom, measures were implemented in 2011 and 2012 which closed access to mid-level jobs, such as IT technicians, to non-EEA labour migrants.

48. On the other hand, some EU countries have responded to the crisis by implementing additional restrictions on temporary workers. In 2011, the Dutch government further restricted the issue of temporary work permits. In addition, the Czech Republic has limited the extension of work permits to six months for jobs where a lower qualification than secondary education were specified. Spain reduced its occupation shortage list and employers were limited to offering temporary work contracts initially. The LMT was extended from 15 to 25 days.

49. Some EU countries have intensified efforts to foster the recruitment of skilled labour migrants by revising their labour migration frameworks to facilitate labour migration, outside of EU Blue Card initiatives. Germany introduced more favourable criteria to recruit skilled foreign workers in 2012, extending exemption for the LMT and granting default approval after two weeks of public advertisement in case of no response (OECD, 2013). ${ }^{8}$ Hungary and Slovakia have also simplified the application process for skilled migrants to get a residence permit.

\section{Defining high skilled migrants in European countries}

50. All EU Member States provide permits for high-skilled or highly qualified migrants. The criteria - educational qualifications, work experience, wage and job offer - and whether there is an actual definition of "high skilled", however, varies considerably between countries.

\section{Education requirements}

51. Regarding the implementation of the EU Blue Card, in addition to salary thresholds as discussed above, there is an education threshold ( 3 years of tertiary education, with the option to allow 5 years of work experience to substitute for this).

52. Outside of the Blue Card, exceptions regarding work experience of qualification requirements can be found. The Czech Green Card, eliminated in 2014, required a certain level of education and work experience.

53. Many European countries make it a necessary requirement to have foreign qualification recognized in the destination country. When the foreign worker applies in a regulated profession or sector such as physicians or other health workers, the migrant's qualification must always be assessed and recognized by the destination country. For example, under the Irish Critical Skills Permit, a copy of registration with the appropriate medical body or a validation of qualifications from the Department of

8 In order to help identifying labour market needs, the German Ministry of Labour and Social Affair introduced a "Jobmonitor", determining manpower shortage by sector and qualification and draw forecast with regards to those needs until 2030. 
Health and Children has to be provided. For unregulated professions, there is a wide range of requirements. Countries with labour migration programmes based on skills generally require proof of qualifications to perform the job. Most such programmes require - as in Luxembourg, for example - that the foreign national show a document attesting that qualifications match the required level for the job mentioned in the work contract. Where there is no skill threshold in the programme - as for general labour-market tested programmes in Italy, Spain, Hungary and Sweden, for example - there is no need to prove qualifications.

54. Obtaining recognition of foreign qualifications can be a lengthy and complicated procedure, especially for third-country nationals holding qualifications acquired outside of European or OECD countries. Legalised translations and notarised diplomas may be necessary, and it may be difficult to demonstrate equivalency for degrees from institutions which are not known in Europe. Several European countries have implemented new measures to help aspiring immigrants assess their foreign qualifications. Germany's new law on recognition of foreign qualification is one example, guaranteeing foreigners a right to have their qualifications assessed, although there is still no evidence of whether it is successfully used by job seekers abroad to find employment in Germany. Sweden has set up new agencies responsible for those evaluations and Ireland has created a new qualifications authority to facilitate the assessment of foreign qualifications.

\section{Salary as a proxy for skills}

55. Salary is always a consideration in the evaluation of labour migration requests where a job offer is involved. While not all permits have an explicit wage threshold, requests are generally reviewed for conformity with minimum wage, collective agreements, minimum standards or prevailing salary conditions, so that in practice all labour migrants have a legal minimum wage requirement. Any job submitted for a labour market test generally must specific the salary offered.

56. In the effort to set a fixed threshold for evaluating labour migration applications, a number of European countries use salaries as an indicator of the skill level of the job and whether it should allow admission. Salary thresholds may be used as the main feature or as an element of admission. The salary is used to indicate productivity or value of the employee, sometimes substituting for other proof of qualifications. It may also be used to protect local workers from wage competition. This is why, for example, the UK government charged the Migration Advisory Committee "to ensure that Tier 2 migrants are not undercutting the UK labour force", although the committee itself did not express its support for this rationale (Migration Advisory Committee, 2015). It is also one of the main criteria - perhaps the most visible one - for the issuance of the EU Blue Card for highly qualified employment.

57. One issue with a salary threshold is whether it results in clustering, i.e., a disproportionate number of individuals earning just above the salary threshold relative to those earning just less than the threshold, or a distortion of the normal salary distribution with a peak just at and above the threshold. The clustering effect can reflect employers increasing their wages to meet the requirements, but can also reflect that employers exploit the greater supply of foreign workers to offer only the minimum necessary salary to meet the requirements. In a 2015 analysis, the MAC found that "for most occupations, the salaries paid to Tier 2 migrants cluster around the minimum salary thresholds set out in the Home Office codes of practice" and indeed do not reflect the salary distribution of the UK labour market in general (although this may reflect the age and experience of the migrants). Figure 2 shows an example of salary clustering under the United Kingdom's Tier 2 programme for a specific occupation. While the general population earns salaries which are distributed more smoothly, those admitted under the salary threshold cluster close to the threshold for the occupation.

58. 
Figure 2. Salary clustering is common when a salary threshold is imposed

Salary distribution for IT business analysts, architects and systems designers (2135) for the UK and Tier 2 (General)

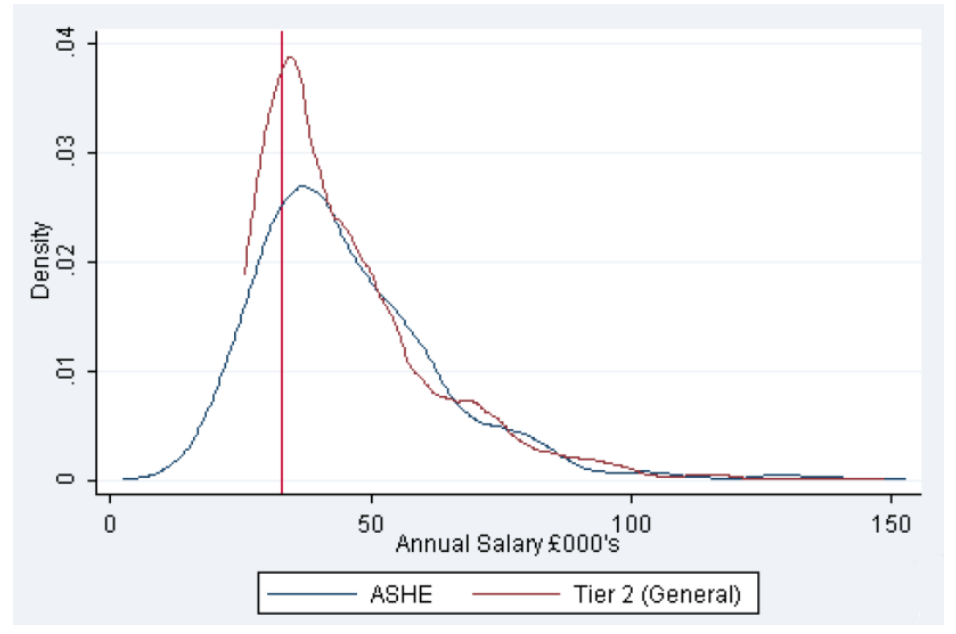

Source: Home Office management information and ASHE 2014, in MAC (2015).

59. Another concern with thresholds is wage discontinuity. This occurs when a higher threshold is set at an age limit, and salaries do not increase with age fast enough to meet the higher threshold. This leads to a gap in salaries between those below and above the threshold. Such discontinuities might just reflect unrealistic expectations about wage increases by certain ages, but also might be explained by employers exploiting the greater willingness of foreign workers to accept lower wages. One test case can be seen in the Netherlands, where salary thresholds jump at age 30. About three-fourths of labour migrants under the Dutch scheme earn more than the post-30 threshold even before reaching age 30 (OECD, 2016). The salaries of workers at age 29 are lower than those at age 30, but largely reflect the regular wage progression as individuals age. However, at least $10 \%$ of the 29 -year olds starting under the scheme earn less than $85 \%$ of the salary they would be required to earn the next year, so there is some evidence of discontinuity.

60. Skilled labour migration schemes may, however, not make this explicit or set a single public benchmark. In Sweden, the lowest collective agreement represents the floor for work permits. Other countries may set a general threshold. Romania will not consider any applications where annual salaries are below about EUR 6 500. The absence of a fixed threshold does not mean that none applies. The Slovak Special Purpose Permit and Research and Development Permit doesn't stipulate any wage requirements, yet applications with very low salaries are likely to be rejected.

61. The EU Blue Card directive is explicit about this aspect: "the gross annual salary [...] shall not be inferior to a relevant salary threshold defined and published for that purpose by the Member States, which shall be at least 1.5 times the average gross annual salary in the Member State concerned". The directive does not specify a single benchmark, such as national account data or survey data. It also does not require countries to use full-time equivalent income. As countries took advantage of a wide range of potential benchmarks, the actual correspondence to a single benchmark is quite wide (Figure 3 ). The range in absolute terms is enormous - from 8200 in Bulgaria to 69900 in Luxembourg - but this range is to be expected given the different GDP per capita in these countries. Using standardised figures on average gross salary (from OECD or, where missing, national statistics institutes), most of the countries place their thresholds between 1.23 and 1.7 times the published average. There is one outlier where the threshold has been applied far below even the statutory indicator of $100 \%$ of the gross annual income: Italy. Here, the 
reference value used was not the average salary, but rather the minimum income below which health care co-payment charges are exempted. In Portugal, the benchmark is just about the average. ${ }^{9}$ Only two countries have high threshold values: Lithuania at 2.7 and Romania at 3.6 times the average gross salary. This is intentional. These countries explicitly chose a higher multiple than 1.5 to calculate their thresholds ( 3 and 4 times the national benchmark, respectively).

\section{Figure 3. Differences in average salaries mean widely divergent salary requirements for highly qualified work permits in Europe}

EU Blue Card thresholds, required salary as a percentage of the average annual gross income of full-time employed, 2014

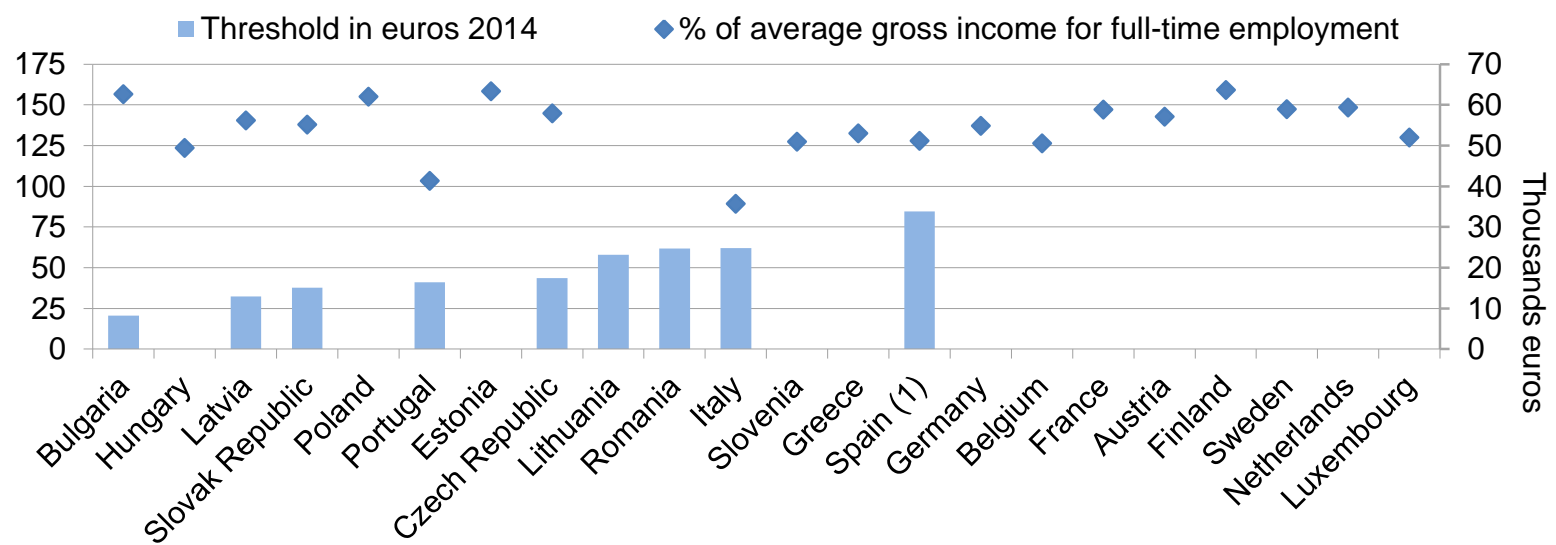

Source: OECD average gross income, March 2014 exchange rates (HUN, BLG) (2014 average for CZE, ROM, SWE, POL). (1) Spain uses an occupational benchmark; the mean is shown.

62. The Blue Card is not the only permit to use salary criteria for admission. In a number of EU countries, the Blue Card exists alongside other work permits which use salary thresholds as one of the main criteria (Figure 4). In most cases, the alternative permit has a lower salary minimum threshold than that applied for the Blue Card. Countries such as the Netherlands and Austria, which have invested effort in developing national schemes for skilled workers, have set the thresholds for the new Blue Card higher than those for the existing schemes, to ensure that the latter remain attractive. Estonia applies a general multiple of 1.24 as a baseline for admission of foreign workers, and 2 for top specialists.

Portugal's Blue Card applies 1.5 times the gross average national salary. In practice, if the Remuneração média mensal de base is taken as the national reference value, this stood at 16419.24 in 2013. However, its national scheme allows for 1.5 times the gross national salary, or an alternative of three times the valor indexante de apoios sociais, or IAS. It appears that the IAS-based threshold (15091.92) is also applied to requests for Blue Cards, which brings this below the OECD full-time equivalent gross annual salary. 
Figure 4. Salary thresholds are used for permits in a number of European countries

Required salary as a percentage of the average annual gross income of full-time employed, 2014, Blue Card vs. other salary-based permits

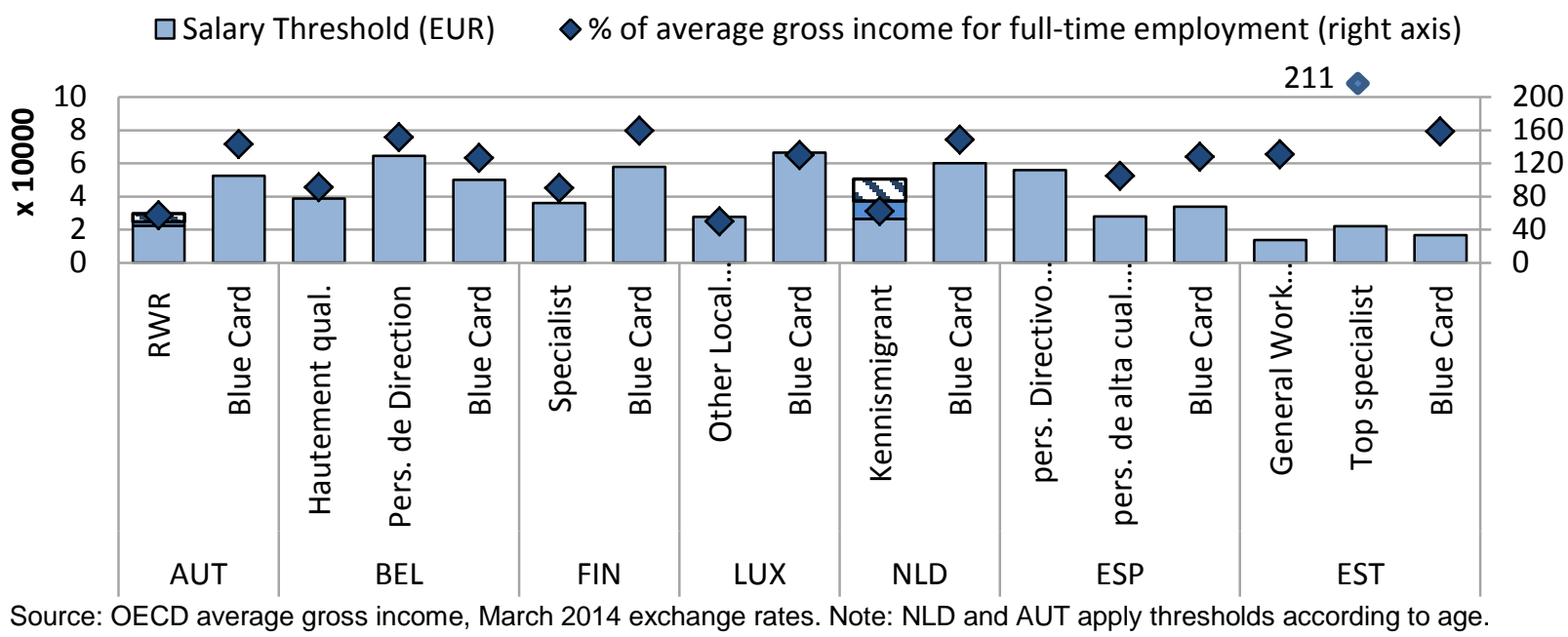

63. Even in the three EU countries not subject to the Blue Card directive, salary thresholds are used for admission (figure 5). Denmark's salary-based JobCard uses an income threshold which is only 92\% of the average gross income for full time employment; this channel is the main stream for labour migration in Denmark, and the salary is the main criterion. In Ireland, the threshold is set higher, although below a hypothetical Blue Card level. A 10\% reduction in the threshold is provided to newly graduated non-EEA students - regardless of whether they have graduated from an Irish or overseas institution - as long as they are in fields which is on the Highly Skilled Eligible Occupations List. In the United Kingdom, basic requirements for the Tier 2 stream - subject to substantial additional conditions - are one-third the national average income, although inclusion on the shortage list requires occupations to pay above the national average. The Migration Advisory Committee in 2010 proposed setting the minimum salary at GBP 20000 per year, placing it at the $30^{\text {th }}$ percentile of earnings distributions for all full-time workers. In the UK, the salary level also determines the number of points awarded to requests for non-EEA workers, and the points have also been object of analysis. Points determine which requests are likely to be successful when the quota is exceeded, as it has since June 2015. 


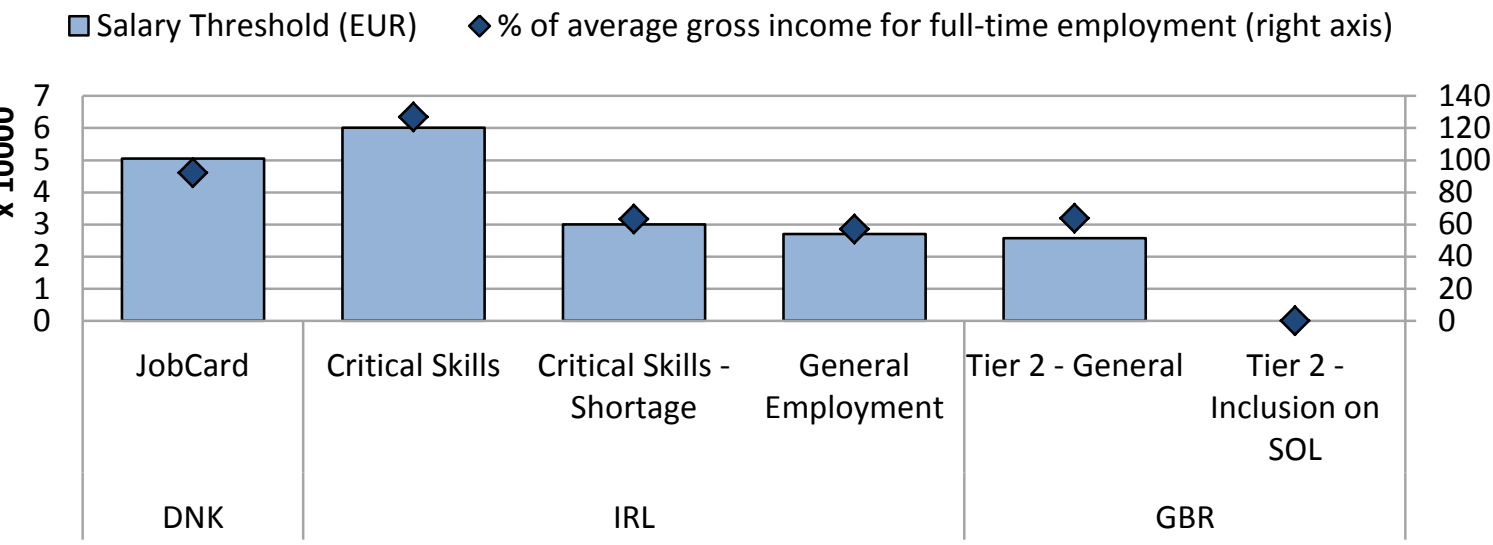

Source: OECD Secretariat analysis.

\section{Using Points-Based Systems}

64. Several European countries have introduced a point-based system (PBS) to select migrant workers. The system is most often closely linked to shortage lists, with additional points being granted for shortage occupations. Since 2008, the United Kingdom, Denmark, the Netherlands and Austria have introduced PBS in their migration selection channels. While modelled on the long-standing examples of Australia, Canada and New Zealand, these European PBS do not grant permanent residence.

65. Austria rolled its previous labour migration system into a PBS-based system starting in 2011 (OECD, 2014c). Total inflows rose slightly under the new system, although the number of immigrants who entered under the PBS who would not have qualified under the old system was very small, only a few hundred. The Austrian experience reveals one of the pitfalls of using a PBS in what is essentially a demand-driven and uncapped system, so that rather than prioritising candidates, the PBS may just confuse employers and applicants.

66. The Point-Based system allocates different points or weighs to a number of parameters such as qualifications, skills, language proficiency, age, experience, or wages. The objective is to sort the best labour migrant candidate for selection and thus to target higher skills by generally specifying higher levels of education, work experience, and local language proficiency.

67. As an example, the United Kingdom Tier-2 for non-EU citizens with a skilled job offer ranks applicants according to characteristics of the occupation (shortage, high qualified occupation etc.) and the prospective salary if the monthly allotment is exceeded - a circumstance which has not yet occurred.

68. Furthermore, mandatory salary thresholds apply for some criteria in certain countries, even before being able to claim any points. This is the case for such criteria as a job offer for the Austrian RedWhite-Red Card and in the United Kingdom, and wages in the United Kingdom where the minimum limit is set at GBP 20000 (see figure 4 and 5 above).

69. Academic qualifications most often represent the key criterion to allocate points and hence select skilled migrants, except for the UK Tier 2 General visa. The weight attributed to qualification and 
education might vary, but generally represents a large part of the provided points. In the Netherlands, weight attributed to general qualification is $86 \%$.

70. Work experience is also a critical part of the PBS. Additional points are sometimes provided for experience within the destination country or in a specific position.

71. PBS require evaluation in order to verify if the points are indeed calibrated to correspond to characteristics which contribute to success in the labour market. The Danish Green Card example discussed above suggests how PBS may not be predictive of success. European PBS are still on their first rounds of evaluation, although the share of participants who qualify for a work permit under skilled work programmes do not appear to be lower than similar programmes in non-EU countries (OECD, 2014a).

\section{Attracting and retaining skilled migrants}

72. The more EU countries position themselves to compete for talents worldwide, the more their labour migration policy frameworks have been adjusted to attract skilled migrants and ensure that they stay. This is evident in policies for international students, permanent residence, family reunification and naturalisation. Foreign students may sustain university enrolment and contribute to the youth workforce, but they are also potential future skilled workers and most EU countries have looked at various ways to attract them. In addition, maximizing the retention rate of skilled migrants in the host country requires attractive policy frameworks, enabling smooth transition towards permanent residency, along with good conditions for family reunification.

\section{Student permits}

73. Attracting international students has direct implication for labour migration policies. Supporting the export of education sector impacts directly the domestic labour market, especially in terms of employment during studies and possibilities to remain after graduation.

74. International students are an attractive workforce for European countries as they provide a source of labour and prospective future skilled workers. Certain countries have tried to increase the internationalization of their higher education and contribute to building knowledge-based economies.

75. The 2004 EU Student Directive explicitly provides a right to work for non-EEA students after the first year of study. Recent jurisprudence by the EC Court of Justice means that there is a right to a residence permit for students fulfilling the requirements of the directive.

76. Most European countries grant the right to work to third country students before the completion of their studies (Figure 6). The amount of time international students are allowed to work is usually capped, or students need to apply for a separate employment authorisation to exceed the authorized amount of time. For example, since August 2012, international students in Germany are allowed to work 120 full or 240 half days in a year, without specific authorization from the Employment Agency. A foreign student can also work for 24 hours per week in Hungary during term-time and up to 90 days or 66 working days per year beyond term time, without the need for a work permit for the period of the full-time studies. The Italian residence permits for study purposes entitles foreign nationals to have subordinate work for no more than 20 hours a week and for a maximum of 1040 hours a year. Estonia, in 2013, lifted the work authorisation requirement for international students, who may work as much as they wish as long as this does not hinder studies. This is also the case in Sweden. Lithuania, however, applies a strict LMT to requests for work authorisation from international students, so that the option is rarely used. 
Figure 6. Most EU countries grant right to work to international students, although hours vary

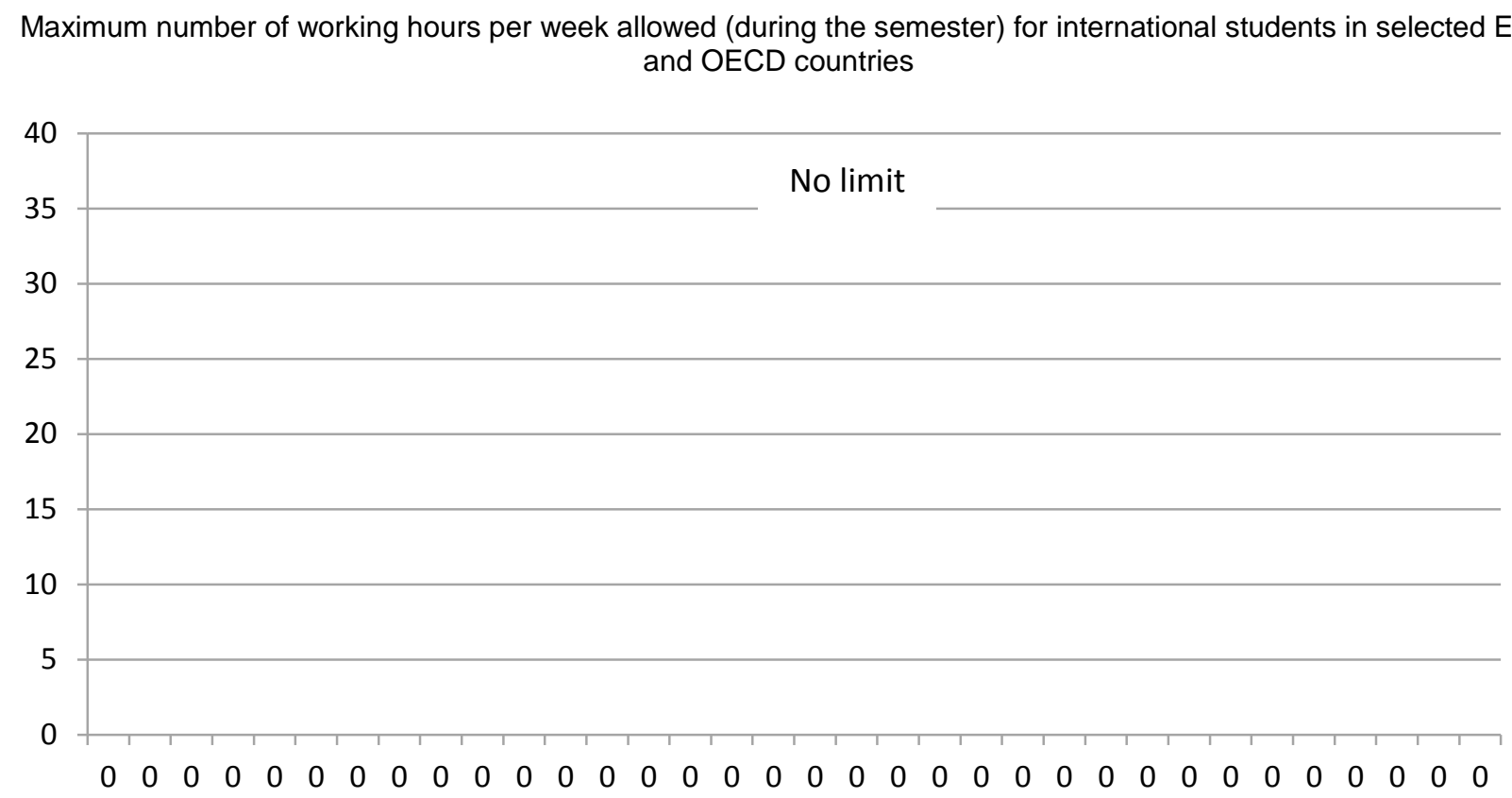

Source: OECD Secretariat analysis. Note: In Lithuania, authorisation is subject to a LMT. Czech Republic figures indicate exemption from work permit; it is possible to receive a work permit if this "does not interfere with studies".

77. International students may also be exempted from labour market test as long as they work less than the specified time limit. In Austria, employment permits may be granted without labour market tests if students are employed for up to ten hours per week or for up to 20 hours per week, provided that they have completed a Bachelor's program or the first part of a diploma program. In the Czech Republic, students may work up to 30 days a year without a work permit, but must request authorisation from the Ministry of Labour and Social Affairs for any job offer beyond this period; authorisation is granted if the employment does not interfere with studies.

78. Some restrictions might apply for specific type of work, such as unremunerated traineeship and volunteering job, which for example are not allowed under the Portuguese residence permit. In Spain, foreigners admitted for study, research or training, non-working or volunteer practices may be authorized to engage in employed or self-employed activity, to the extent that it does not limit the pursuit of studies or assimilated activity.

79. Many but not all European countries allow international students to remain in the destination country after completion of their studies to undertake job search (Figure 7). The tendency in the past few years has indeed been to foster measures that could increase the attraction and retention of foreign graduates (OECD, 2014a). Post-graduate visas are the main tool to encourage the retention of foreign graduate students. 
Figure 7. Many EU countries don't allow students to extend their permit beyond graduation to search for employment

Post-graduation extension duration (months) for job search for non-EEA nationals in selected EU and OECD countries, 2015

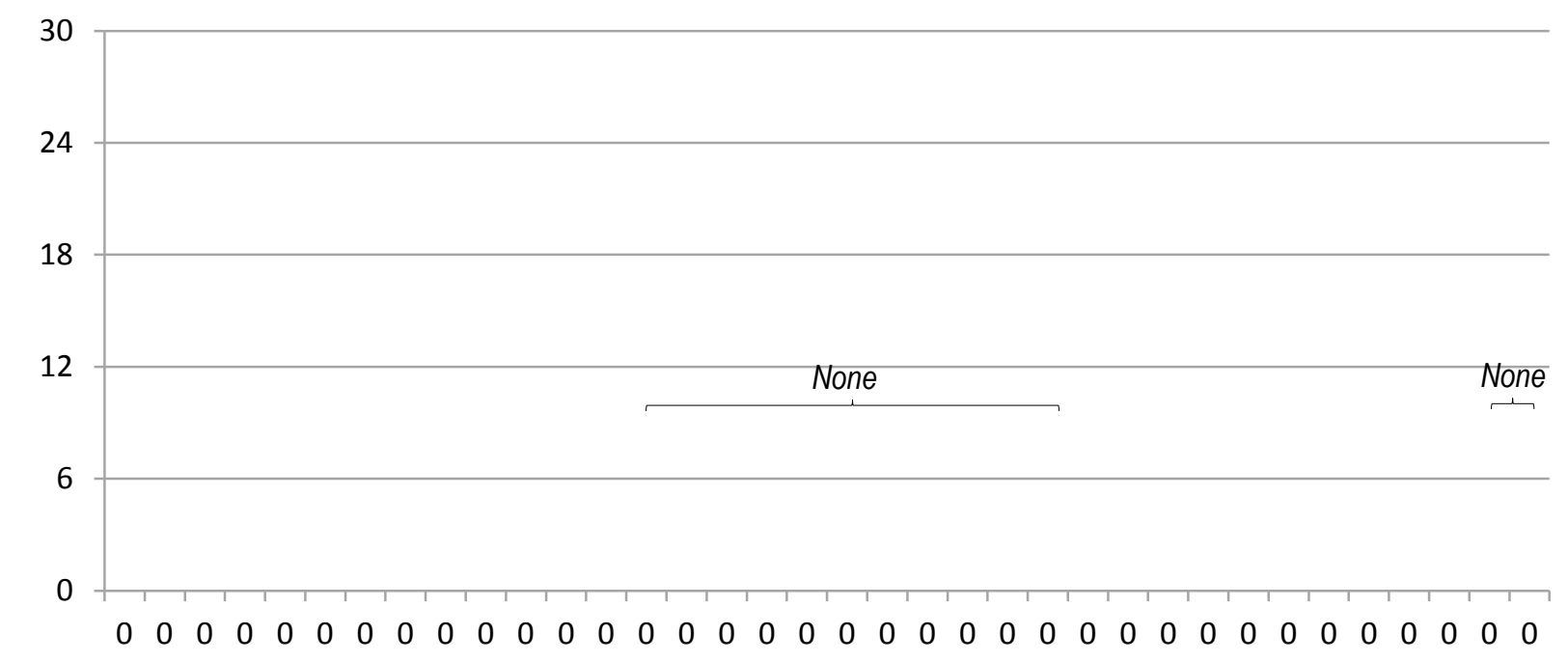

Source: OECD Secretariat analysis.

80. The duration allowed varies between 6 months in countries like Austria and Denmark, up to one year in Finland, Italy and in the Netherlands, to up to 4 years in the case of doctoral students. In Germany, foreign students may be granted an additional 18 months of residence in Germany to seek employment in their field of study upon successful completion of their educational program (within the required program duration). In Slovenia, changes are allowed up to two years after graduation.

81. Other European countries don't provide any specific prospects for staying on beyond graduation, so graduates must therefore use the existing labour migration channel when and if they find qualifying employment. Belgium, Greece, Hungary, Latvia, Portugal, Spain and the U.K. don't propose any postgraduate job-search permit.

82. International graduates are sometimes required to find a job in the host country related to their field of study; this tends to reflect the level of restrictions for work permits. In such cases, however, students benefit from preferential treatment by being exempted from the LMT, as is the case in Luxembourg. Where it is a condition for status change, matching job and qualification requirements can be a concrete obstacle. Germany, for example, grants a long job search period but tends to apply a very rigid interpretation of this condition. Not only can science graduates not work in humanities occupations and vice versa, but even the specialty fields are sometimes expected to match, at the discretion of the local labour office deciding the application. Germany only grants this status-change and job-search extension to students who have finished their degree within the standard time (5 years), which may penalise students whose graduation is delayed by their need to work during studies. In France, a very rigid interpretation of the status-change condition imposed in May 2011 represented an obstacle to post-graduate status change until a new government in 2012 issued a memorandum allowing a looser correspondence to be applied. Finland, on the other hand, exempts graduates from the LMT even when the job they find is low-skilled. 
83. The extension may vary according to the level of study. This is the case in Ireland, for example (as well as in Korea). Sweden goes further for graduates with the highest qualification: from 2014, foreign doctoral graduates may receive a permanent residence permit, regardless of whether they have employment.

84. The job search extension is of more importance when the transition to employment for graduates (whether EU nationals or third-country nationals) is longer, and plays more of a role in the transition when criteria for work permits are stricter. Where no skill or salary thresholds are applied, as in Finland, Hungary, Sweden or Spain, it is simpler for graduates to obtain work permits for jobs right out of university. If jobs must match qualifications - as in Germany and France - and most graduates don't find matching jobs until months after leaving university, then the job search extension is a major factor in ensuring transition.

85. Not all countries have concentrated efforts on attracting international students. Several have imposed restrictions aimed at limiting the number of new entries of international students, generally aimed at reducing abuse of the study channel for other purposes, such as employment. To prevent "eternal" students, for example, the Slovak Republic introduced a 6 year limit to the number of years allowed on a study permit. Likewise, non-EEA student residence is limited to 7 years in Ireland for degree level course and to 3 years for sub-degree level. The United Kingdom has reduced the recruitment of international students as a way to meet its net migration target. Closer monitoring of the recruitment of foreign students was put in place from 2011 through sponsor requirements, and additional restrictive measures were introduced in $2012 .{ }^{10}$

\section{Granting permanent status}

86. Permanent residence status exists in all EU countries, which had such a status in place even before the Long Term Residents Directive was transposed. Permanent residence provides privileges that are not granted to temporary workers, typically free access to the labour market without restriction on employer, occupation or salary; eligibility to apply for citizenship; greater access to social security and health services; and even political participation and the right to vote in local elections. A pathway to permanent residence can then be a strong incentive to choose a country of destination for high-skilled migrants.

87. Options to gain permanent residence from work or study depends on various considerations such as the time spent in the destination country for work or study (usually five years, although years as a student may count for half or nothing), along with a different set of prescribed conditions such as offer of permanent employment, wage or income, skills level or language tests.

88. In addition, permanent residence criteria, such as language tests, can be discouraging, even for skilled migrants. Such requirements are imposed in many European countries such as Sweden, Italy, and Denmark). A wide knowledge of the host country language, culture and society is also a requirement in Austria, Czech Republic, France, Hungary, Latvia, and Germany. In the U.K., since October 2013, all applicants for settlement have to pass the "Life in the United Kingdom" test and have a speaking and listening qualification in English.

89. The transition from temporary residence to permanent residence corresponds to the end of restrictions on employment requirements. However, even before permanent residence, there is still the question of how long foreign workers should be bound to all the initial conditions on which their admission

10 From 1998 to 2014, Italy imposed an annual limit on the number of international students. The limit, originally intended as a safeguard, was invariably set so high as never to affect enrolment. 
was contingent. For example, if they are admitted for a specific labour-market tested job, they may be bound to their employer, occupation, sector or even region of employment, with any changes requiring a new review of the application. For renewals with the same employer and the same occupation, only Ireland may impose a new labour market test. However, other countries may lift restrictions on labour market mobility even before granting permanent residence. Generally this occurs at the end of the first temporary permit or after one or two years, although basic income conditions and occupation requirements must continue to be met. In Italy, for example, admission grants total immediate labour market mobility. In Spain, an occupation and region restriction is lifted after the first year. Sweden and most other countries apply a labour market test for all job changes. For countries with skill requirements, job mobility may require meeting all the initial conditions, including that education correspond to the occupation.

90. The five year benchmark for permanent residence can be traced as far back at the 1950s, when the OEEC set the time limit for lifting restrictions on labour mobility at five years. It also, however, provided that member countries try to reduce this period.

\section{Family reunification measures}

91. One critical measure to attract and retain skilled migrant is family reunification. Most migrant workers in the European Union are allowed to bring families, except those on limited duration temporary work such as seasonal work. Specific conditions apply when family reunification is authorised, such as income thresholds.

92. All workers have a right to family reunification under the 2003 Family Reunification Directive, although this can be subject to a one-year residence requirement, a perspective of permanent residence, and sufficient income levels (as well as housing and insurance requirements). Skilled workers enjoy the right to accompanying reunification under the EU Blue Card channel. For some other migration channels, including those for highly qualified workers, the principal migrant need to have been granted unlimited residence authorization for at least one year in the host country before being eligible to family reunification (e.g., the Belgium B Work Permit). Similarly, a non-EU national must hold an Italian work permit valid for at least 12 months before being eligible to apply for clearance to preserve or to reacquire family reunion. In Ireland, a foreign national with a work permit can only be joined by their family after becoming a "qualifying sponsor", while family reunification is automatically granted to skilled migrants recruited under the Irish Critical Skills scheme (or to Intra-Company transferees).

93. Though family reunification is usually an attribute of high-skilled migrant visas, some countries can also grant this right to temporary or seasonal workers. In Belgium, workers that are granted a visa for less than a year can apply for family reunification. Likewise, the Portuguese work visa and temporary visa both allow for family reunification.

94. Access to the destination country labour market for accompanying family members is at the core of family integration and is a key element to attract and retain of labour migrants. An open work permit is usually explicitly and immediately available to joining family of high-skilled workers. In any case, for countries covered by the EU Directives, family members acquire labour market access.

95. Dependents of skilled migrants are generally granted an open access to the host country labour market. There are some exceptions. In the Netherlands family members of skilled migrants are not eligible to work under their status but may only be sponsored for a work permit by a Dutch employer under the regular programmes, with no facilitations. Germany had a complex mix of work rights for family members - some eligible, some not - but from 2012 extended work rights to all family members of skilled migrants. The EU Blue card embeds the right for the dependent to have automatic access to the labour market. 
96. Family migration policies have tended to become more restrictive in terms of admission over the past few years, even if exceptions can be noticed. Some criteria have become tighter, salary thresholds have been increased, or the introduction of higher requirements regarding the knowledge of the host country language and culture have sometimes become a tool to reduce family migration. This has had an effect on labour migrants' family members even if they were not the target group of these restrictions.

97. Other avenues have been used to narrow family reunification and formation, such as rigorous conditions imposed on sponsors, or more stringent residence and maintenance conditions. The United Kingdom and Denmark have tightened up on sponsorship requirements for relatives in the host countries. New financial requirements were set (a minimum gross annual income threshold of GDP 17600 for a person sponsoring settlement in the U.K.) In the Netherlands, the government since 2011 has limited family reunification to the core family and a one year waiting period has been introduced for migrants who wish to bring their family, during which dependents must prepare their integration in the host country.

\section{Access to Naturalization}

98. Since long-term migrants have invested time in the country of destination, eligibility to gain access to the host country citizenship would normally follow permanent residence, although there are no fast-track pathways to naturalisation specifically for highly qualified labour migrants. Time duration for eligibility varies from the moment when long-term or permanent residence has been granted, as do the eligibility conditions. For example, in the Czech Republic, Sweden, and France, eligibility for naturalization is 5 years after gaining permanent residence permit. In Greece, an alien who is not an ethnic Greek must live in Greece for seven years before applying for naturalization. Requirements can go up to 10 years in Austria, Italy, Slovenia and Spain. Minimum duration requirements, however, are not the only factor, as additional requirements (income or self-sufficiency requirements, language acquisition, etc.) also vary.

99. Relative to long-term residence status, which grants labour market mobility, naturalisation may represent additional benefits for foreigners. It ensures mobility within Europe, allows longer absences, and eliminates any barriers to full use of public goods. It also allows employment in public sector or other occupations reserved for nationals.

\section{Complementary channels that support labour migration}

\section{Youth mobility}

100. Working Holiday Maker Programs are in place in many European countries and are primarily instruments to promote youth mobility. Those schemes usually result from formal treaties or agreements between countries and generally have a cap or quota attached to the numbers of nationals that can be granted such visa on a reciprocal basis. Though the objectives combine both cultural and social reasons, these programs provide a significant additional resource of labour and has then economic implication.

101. Programs usually limit the amount of time a migrant can work out the total allowed duration of stay. The Irish Working Holiday Permit only covers work of a casual or temporary nature, while in Belgium, the working time under the Working Holiday Program is limited to 6 months out of a one year visa.

102. In practice, youth mobility programmes in Europe involve relatively few individuals, with the exception of the United Kingdom, especially when compared with their counterpart programmes in Australia, Canada, New Zealand and the United States. In these countries, the magnitude of the programmes mean that specific industries and sectors rely on it to answer seasonal demand for workers. 
Foreign policy goals

103. Many individual European countries have signed bilateral agreements that embed labour migration provisions. Those bilateral arrangements typically cover seasonal, guest and holiday workers movements between countries. They can take the form of Treaties, Travel Agreements, Memorandums of Understanding or Inter-Agency Agreements between government agencies.

104. Bilateral Agreements also often provide clauses for vocational training or filling positions in shortage occupations. Italy has attempted to shift its labour migration channels to recruitment based on training in the country of origin and has thus reserved a quota within its migration program for participants and funding training initiatives. Spain used bilateral labour programmes during the peak years of international recruitment in the mid-2000s; these programmes are still used largely for seasonal workers. Likewise, Germany establishes quotas for contracted workers from a set of countries with which Germany has signed a bilateral agreement.

105. France has signed bilateral agreements on co-development with a number of African countries, embedding provisions on the fight against irregular migration, the prevention of brain-drain and the contribution of labour migration to development. These agreements contain facilitations for labour migration.

\section{Summary and Overview}

106. The obstacles encountered by labour migrants can be at different phases of the selection criteria (Table 1). What is evident in the table is that a job offer is a fundamental requisite for labour migration in Europe. Skills thresholds are in place in a number of countries. The labour market test, for most skilled workers, is a nominal barrier, and numerical limits are not applied to skilled workers. 
Table 1. The barriers to labour migration in selected EU countries

\begin{tabular}{|c|c|c|c|c|c|c|}
\hline & $\begin{array}{l}\text { Job } \\
\text { offer }\end{array}$ & $\begin{array}{l}\text { Skill / } \\
\text { Occupation } \\
\text { al } \\
\text { Threshold }\end{array}$ & $\begin{array}{l}\text { Labour } \\
\text { market } \\
\text { test }\end{array}$ & $\begin{array}{l}\text { Shortage } \\
\text { occupati } \\
\text { on list }\end{array}$ & $\begin{array}{l}\text { Numerical } \\
\text { limit }\end{array}$ & $\begin{array}{l}\text { Seasonal } \\
\text { work } \\
\text { programm } \\
\text { e }\end{array}$ \\
\hline Sweden & Yes & No & $\begin{array}{l}\text { Yes, } \\
\text { but... }\end{array}$ & Yes & No & Yes \\
\hline Spain & Yes & No & Yes & Yes & No & Yes \\
\hline Portugal & Yes & No & Yes & No & Nominal & No \\
\hline Hungary & Yes & No & Yes & No & Nominal & Yes \\
\hline Finland & Yes & No & Yes & Yes & No & Yes \\
\hline Poland & Yes & No & Yes & No & No & Yes \\
\hline Greece & Yes & No & Yes & No, but & Yes & Yes \\
\hline Italy & Yes & No & Yes & No & Yes & Yes \\
\hline France & Yes & Yes & Yes & Yes & No & Yes \\
\hline Germany & Yes & Yes & Yes & Yes & No & Yes \\
\hline Bulgaria & Yes & Yes & Yes & Yes & No & No \\
\hline Belgium & Yes & Yes & $\begin{array}{l}\text { No, } \\
\text { but... }\end{array}$ & No & No & No \\
\hline Netherlands & Yes & Yes & Yes & No & No & No \\
\hline Estonia & Yes & No & $\begin{array}{l}\text { No, } \\
\text { but... }\end{array}$ & No & Yes & No \\
\hline Czech Republic & Yes & Yes & Yes & Yes & No & No \\
\hline Austria & Yes & Yes & Yes & Yes & No & No \\
\hline Denmark & No, but & No, but... & Yes & Yes & No & No \\
\hline United Kingdom & Yes & Yes & Yes & Yes & Yes & No \\
\hline Ireland & Yes & Yes & Yes & Yes & No & No \\
\hline
\end{tabular}

107. In the European system, where employer demand is the principal requirement, there is no direct competition among countries for individual skilled migrants, since the applicant for a work permit must 
have a job offer from a specific employer in a specific country. It is in theory possible for candidates to apply for employment in different countries, receive job offers and choose the destination based on the work permit conditions, creating a competition on these grounds. Similarly, a worker could seek employment in countries with favourable conditions, but there is no evidence that workers are flocking to EU countries with favourable permit conditions. Competition is more direct and explicit between countries for the location of enterprises by offering ease of recruiting third-country workers. These conditions have been advertised by Ireland as an advantage for companies establishing their operations in the country. Another form of competition is in making it simpler in general for enterprises to recruit from abroad, leading them to search more actively to fill vacancies from abroad relative to enterprises in countries with restrictive conditions. Finally, the conditions for renewal and acquisition of permanent residence may make a country more competitive in terms of retention, as do conditions for family reunification and integration.

108. The perception of users of labour migration - employers, workers and intermediaries - may not correspond to the objectives of policy makers in establishing admission criteria. Most users will seek the simplest, fastest and least costly route to admission. This has important implications for the implementation of European directives and the uptake of permits created to respond to these directives. The benefits of certain permit categories such as the Blue Card may be superior to those of other permits. However if these differences are not substantial and other permits are easier to obtain, most labour migrants will gravitate towards the most direct route.

109. Traditional labour migration schemes impose rigidities on the labour market in a time of increased flexibility. One example is the minimum job offer required for many of the labour migration permits in EU countries. In countries with rigid labour markets, there may be few employers ready to offer a one year contract to a worker abroad they have never met.

110. In light of the differences in the above table, is it possible to consider Europe as a single destination compared to other OECD destinations? How do admission conditions in the EU for migrants compared to those in other OECD destinations? Based on the analysis presented in this paper, Annex table A.2 attempts such a comparison. The United Kingdom is treated separately from the rest of the EU, as it is not covered by EU instruments in migration (Ireland and Denmark, also not covered by most EU instruments, are not included in this table). This overview reflects the variation among EU countries. What stands out is the relatively limited offer of permanent residence to newcomers; the fact that only in Europe is there still a possibility of long-term labour migration for low skilled occupations - albeit in a limited number of countries. Since highly qualified workers are not subject to limits, there is no backlog and effective migration levels are based on variation in demand rather than targets. For less qualified workers, this is true for Sweden, while in other countries numerical limits and severely applied labour market tests regulate entries at a level which is generally below employer demand.

111. This section has looked at mechanisms in European labour migration policy. It has also discussed some of the practical applications of these mechanisms and how they can hinder labour migration. Skill requirements in many countries mean that low skilled occupations are not eligible for recruitment of nonEEA workers; in countries which do allow these jobs, the LMT and numerical limits are the main barriers. The latter are less stringent for skilled migrants recruited for skilled occupations, but recognition of qualifications and some countries' LMT still represent barriers. This aspect will be explored further in the following section looking more closely at the implementation of the EU directives - principally the Blue Card directive - compared with prevailing and pre-existing systems in European countries. 


\section{THE IMPACT OF EU DIRECTIVES ON THE LABOUR MIGRATION FRAMEWORK IN EU COUNTRIES}

112. EU directives in the field of labour migration are not transposed in a vacuum. As described in the previous section, the labour migration framework in each European country has evolved largely according the specificities of national legislation, national labour market requirements and the politics of migration management, forming a patchwork of approaches. While European Directives in the area of labour migration have influenced national policies, each member country remains responsible, with few exceptions, for the final decision on whether or not to admit a labour migrant.

113. For the EU countries covered by the Directives, transposition is mandatory, so all countries have had to adjust national legislation to accommodate them. In the case of the Student and Researchers directives, existing practice for these categories was largely mirrored in the transposition, although in some countries specific differences were realised.

114. This section examines how national policies have evolved and incorporated the Students Directive, the Researchers Directive and the Blue Card Directive.

\section{Student Directive: affects existing permits}

115. The Student Directive (Council directive 2004/114/EC on the conditions of admission of third country nationals for the purposes of studies, pupil exchange, unremunerated training or voluntary service) sets the rules for entry and stay of international students to the EU. The overall objective of the Directive is to promote Europe as a world centre of excellence for studies. A proposal was presented in February 2003 and already approved by the European Parliament, with amendments, by early June 2003. The Council reached an agreement in the end of March 2004 and the Directive was formally adopted in December 2004. This legislative procedure of less than two years suggests that it did not invoke particularly sensitive issues of national interest. Indeed, negotiations between EU institutions and Member States were rapid compared with other directives. The European Parliament suggested amendments, some of them merely textual adaptations, some enhancing the level of transparency, protection and extending certain rights (such as limiting processing times to 60 days and requiring justification for refusal, however this was not taken into account in the final text). Furthermore, the European Parliament suggested including unremunerated researchers, but this was not included in the final directive either.

116. The Directive does not apply to the UK, Ireland or Denmark, which represented between onethird and one-half of valid student permits in 2013. These three countries had only $23.9 \%$ of all thirdcountry national students in 2003 (despite the smaller number of EU countries).

117. In 2004, all EU countries already had study permits, and in most EU countries the conditions of these permits were already largely in line with the Directive. Therefore, the Directive required few changes in most cases. For example, Belgium, Spain, Finland, France, Italy, Lithuania, Sweden and Romania only modified provisions in their existing permit.

118. In some cases, implementation required more than just renaming an existing student permit. For example in Poland, before the implementation of the directive, international students had to apply for general visas or fixed-term residence permits; no "student permit" existed. Transposition created a student 
category, although the conditions for students remained similar to those previously applied (health insurance and proof of possessing sufficient resources required).

119. In other countries, transposition was an opportunity to expand work rights. For example in Spain, student workers were previously subject to a labour market test in order to obtain a work permit. While students are still required to hold a work permit, the LMT was removed as the Directive was implemented.

120. The Directive includes conditions for admission to the educational institution and adequate financial resources. Furthermore, the directive regulates language proficiency, payment in advance of fees charged by the institution, requirements to make acceptable progress and maximum employment allowed. It also introduced the novelty of intra-EU mobility.

121. Further, the Directive means that applicants who meet the stated criteria must be issued a student permit. The European Court of Justice ruled in $2014^{11}$ that member states could not deny a student visa even if they were unconvinced that the applicant was a bona fide student, as long as the conditions in the directive were exhaustively met. In addition to the ability to reject permits for reasons of security and public order, the directive allows countries to combat misuse of the student route once the student is admitted, through the requirement to meet admission criteria at recognised institutions and to "make acceptable progress". This shifts the burden of compliance first to the government review of eligible institutions and then to the institutions themselves. In fact, the main target for reducing the misuse of the student route has been on the educational institutions rather than the individual applicants.

\section{Language requirements}

122. Language requirements can constitute a barrier for third country national students for accessing studies in a Member State. According to the Directive, a Member State can require the prospective Student to provide evidence of sufficient knowledge of the language of the course that $\mathrm{s} / \mathrm{he}$ intends to follow. Most EU countries primarily offer instruction in the national language(s). For example, in Italy, national legislation requires international students to have an adequate knowledge of Italian in order to enrol in courses taught in Italian. The student must submit either a certificate supporting at least a B2 level, or through an interview with the diplomatic-consular mission and an Italian Institute for Culture (or in another way deemed appropriate). A number of countries chose not to implement language requirements into national legislation, although institutions for higher education may still require proof of sufficient language skills for admission. This is the case in for example Sweden, Austria, Latvia, Spain and the Netherlands.

\section{Requirement to keep up with studies}

123. Renewal of a permit can be refused or withdrawn if the holder does not make acceptable progress in his/her studies according to national legislation or administrative practice. The notion of "acceptable progress" is however assessed differently across the EU. Documentation requirements vary, but national practices did not change as a result of transposition. For example, in Austria, the student has to submit university confirmation of continuation of studies, written proof of the successful course of studies by the university, current record of studies and confirmation of continued enrolment by the university. In France, the 'seriousness of the studies' is also taken into consideration when the student changes curriculum when

\footnotetext{
${ }^{11}$ C-491/13 Ben Alaya vs Germany
} 
renewing his/her permit. In Italy, proof of having sustained a minimum number of exams in the previous year is sufficient for renewal. In Romania, there is no such requirement.

\section{Labour market access during studies}

124. The directive requires countries to grant students labour market access outside of their studies, and sets the minimum at 10 hours weekly, although it allows countries to impose a labour market test and to restrict work access during the first years of study.

125. Most countries already granted labour market access to students, and the conditions were unchanged by transposition. Italy and Belgium maintained a maximum employment period of 20 hours per week. In a few countries, students were not allowed to work at all before the transposition of the Directive; this was the case in Lithuania, which grants 20 hours per week following transposition. In Spain, international students still need a work permit if they want to work outside of their studies; however, the implementation of the Directive eliminated the labour market test for students. The Czech Republic requires a work permit for working more than 30 days annually, as it did prior to transposition. Poland only allowed working during the summer months until 2014, when full-year employment was allowed. The recent change was however not linked to the implementation of the Directive. Only a few countries keep the working hours at the minimum allowed by the directive (Austria, Luxembourg, Netherlands and the Slovak Republic).

126. Most countries did not restrict employment for the first year of studies even before transposition of the Directive. Lithuania maintained its restrictions, and students are not allowed to work during the first study year in the first-cycle (bachelor) or integrated studies.

127. Some Member States used the implementation of the Directive as an opportunity to establish fasttrack procedures. In the Netherlands, it even expanded and became a default for most permits, reducing processing times from three months to two weeks. Spain has specific agreements with Latin American countries for faster processing.

\section{Intra-EU mobility: different interpretations of the requirement not to "hamper studies"}

128. One novelty introduced by the directive was the requirement to create provisions for intra-EU mobility for third-country national students that have been admitted for studies in a first Member State, and wish to continue or complement their studies with a related course in a second Member State. Admission to the second Member State must then be made within a period that does not hamper the pursuit of studies. The provision should have brought about changes in all Member State as none of them had mobility clauses prior to transposition.

129. The directive does not prevent countries from requiring students to apply for a study permit in their home country - it only requires this application to be treated is such a way as not to "hamper studies" while leaving the authorities sufficient time to process the application, without specifying a maximum processing time. Countries have interpreted this differently. Some use maximum processing periods or fast-track processing to respect this clause, while others have provisions of administrative simplification. 
130. Certain criteria can potentially delay mobility. One example is the 'adequate financial resources' requirement, which can affect mobility from lower-cost countries to higher cost countries, since the financial resources necessary in one state might not be sufficient in the other.

131. The provision does not appear to have led countries to change their processing time requirements. A number of countries already had maximum processing times which were left unchanged by the Directive. For example in Finland, processing time remained one month, and in Sweden it around two months if the application is complete. Fast-track processing for students is not used, in general or for intraEuropean applications. This has been the case in Poland, which has not introduced any fast-track for students, and where delays in processing visa applications can lead to problems of admission. Lithuania also applies standard procedures for temporary residence permit, and a decision can take up to four months unless it follows an urgency procedure (doubling the fee, reducing the processing times to two months). This was not introduced specifically for the directive, and intra-European transfers do not benefit unless they pay the fee. If students choose to apply for a national visa, it is usually issued within 15 days.

132. A visa exemption can make a difference, since it allows students to change countries without having to return home for issuance of a visa, or await a new visa in the first country of study. Italy allows international students already residing in another Member State to continue studies in Italy without having to apply for a new student visa in the home country. This allows short stays with no reporting to the authorities. The student must, however, apply for a student permit in case the stay exceeds three months, and all regular conditions apply. Since 2014, the Netherlands has similarly extended the application of national legislation to third country nationals who reside elsewhere within the Schengen area and wish to study in the Netherlands. This visa exemption was not done in the framework of the Directive, but on a national basis.

\section{Little interest in using the directive to regulate other student categories}

133. Most countries ignored the possibility to regulate the conditions for school pupils, unremunerated trainees and volunteers under the same directive, although most countries do have a legislative framework for people in these categories. Nine Member States (AT, BE, DE, FI, LT, MT, NL, PL and SE) transposed only the provisions relating to students. Bulgaria proposed draft legislation on unremunerated trainees and school pupils, Greece on volunteers, France on unremunerated trainees, Hungary on school pupils and volunteers, and Latvia on school pupils. The remaining ten transposed all three categories, but made no changes in the fundamental conditions for these categories. National permits remain applicable for volunteers and pupils where the conditions of the Directive are not met (for example, for volunteers in programmes longer than 12 months, for which the Directive does not allow permits beyond 12 months).

134. Overall, it can be concluded that administrative practices were not changed to a significant extent by transposition of the Students Directive. Intra-EU mobility in practice can be limited by different requirements for study permits and financial requirements. Work rights of students remain variable across the EU, in terms of hours but also work-permit requirements and application of labour market tests.

\section{The Researcher Directive: a new fast-track permit in many countries}

135. The objective of the Researchers Directive (Council Directive 2005/71/EC of the 12 October 2005) is to reduce obstacles to entry and residence of third country researchers to the EU, and to grant 
them mobility rights. The group covered by the Directive is largely defined not by the characteristics of the permit recipient, but by the characteristics of the host institution and on the content of the research project. The Directive provides a broad definition of "research", and defers to national legislation and administrative practice for the definition of "research organisations". "Researchers" must hold higher education qualification giving access to a doctoral programme and whose qualification is normally required for the project underway. In practice this grants a high degree of flexibility, allowing public and private bodies to qualify as hosts, and researchers to have lower tertiary education.

136. The Researchers Directive was finalised quickly. The Commission presented its proposal in March 2004 and an agreement was reached in the Council by November 2004. Ireland informed the Commission in July 2004 that it intended to participate in the Directive; this was the only Directive in the area of migration to which Ireland decided to adhere. The Directive was adopted in October 2005, with implementation by the Member States by October 2007. The two central components, i.e. the specific admission procedure making the research organisation the main interlocutor during the admission process and intra-EU mobility for researchers, were not controversial aspects for the Member States. The idea of a hosting agreement was not challenged, as countries welcomed the idea of making third parties liable for migrant's expenses (Roos 2013). In most Member States, being admitted as a researcher already required invitation by a sponsoring research institute (ICMPD, 2011). However, establishing a legal contract in the form of a hosting agreement was a novelty introduced by the directive.

137. Similarly, the Parliament had no objection to the directive, and its positive opinion was issued in April 2005, after the Council had reached its agreement. The opinions of the two committees (the Committee on Industry, Research and Energy and the Civil Liberties Committee) which examined the proposal both welcomed that the Member States refrained from quotas or economic needs tests, which would have contradicted the objective of attracting TCN researchers (JO C/2005/120/60 and JO $\mathrm{C} / 2005 / 71 / 6$ ).

138. The debate in the Council mainly focused on the autonomy granted to research organisations as they assume a decisive role in determining whether a researcher can be admitted to the Member State, and has the right to intra-EU mobility. Austria and Luxembourg succeeded in restricting this autonomy by limiting institutional approval to a five-year period. This meant that immigration authorities could audit research organisations every five years and verify their trustworthiness.

12 Definitions in Article 2:

(b) 'Research' means creative work undertaken on a systematic basis in order to increase the stock of knowledge, including knowledge of man, culture and society, and the use of this stock of knowledge to devise new applications;

(c) 'Research organisation' means any public or private organisations which conducts research and which has been approved for the purposes of this Directive by a Member State in accordance with the latter's legislation or administrative practice;

(d) 'Researcher' means a third-country national holding an appropriate higher education qualification, which gives access to doctoral programmes, who is selected by a research organisation for carrying out a research project for which the above qualification is normally required; 


\section{A new permit in some countries}

139. While Member States hosted researchers before transposition of the Directive, not all of them had residence permits specifically addressed to researchers. In the Netherlands, Poland and Lithuania, researchers had to apply for residence permit under the general scheme prior to the Directive. In Spain, France and Sweden, a previous permit for researchers was modified in line with the Directive. Italy had a researcher permit already in place, created as a quota exemption under the 1998 law, covering university professors, paid academic staff and researchers in "universities, teaching institutes and research institutes" (art. 27c of law 286/98). Transposition meant separating academics and researchers into two distinct legal categories. Romania had no category for researchers and used the directive as an opportunity to introduce a new type of residence permit for scientific research.

140. In Belgium, the implementation approach did not introduce a new permit, but rather exempted researchers with a hosting agreement from having to apply for a work permit. They can apply for a visa directly, upon showing the host agreement. Researchers without a hosting agreement end up using other (non-research) permits instead.

141. In most cases, Member States national legislations have not literally transposed the definitions included in the directive (such as 'researcher' and 'research organisation'). When the definitions are not clear and uniform across the Member States, there is a risk that the interpretation becomes more restrictive and does not grant them the specific rights and opportunities they are entitled to as TCN researchers (such as favourable rights to reunification).

\section{The Hosting agreement requirement}

142. The Directive requires that a hosting agreement be signed between the researcher and hosting organisation. Hosting agreements look different and are not uniform across countries and even within countries. A standard form provided by a government agency and developed by the national government is provided in Belgium, Sweden, France, Spain, Italy, Ireland and Romania, although these forms are not identical. In Belgium, the standard form is defined in the legislation. By contrast, there are no standard forms in the Netherlands, Lithuania and Poland. The purpose and scope of the hosting agreement can therefore differ across the Member States. While some countries consider the hosting agreement as a specific contract for research purposes, others use it as an employment contract. In Lithuania, the researcher must provide an employment contract concluded with the research organisation.

143. Wage requirements also vary significantly across countries. Some apply the national minimum wage (e.g., Latvia, Lithuania and the Slovak Republic), while others apply a lower wage requirement (Netherlands requires just 70\% of the minimum wage). In France, for doctoral level researchers, national wage requirements apply, of 1.5 times the minimum salary. In Italy, it is twice the level required for social benefits. In all countries, the wage requirement is below that required for highly qualified employees. This may explain the choice of the permit in some countries relative to alternative permits for people employed in research positions, both within and outside of universities.

\section{Intra-EU mobility for researchers}

144. Concerning intra-EU mobility, it is not often explicit in national legislation that TCN researchers can undertake research in their country for up to three months if $s /$ he has been issued a permit in another Member State. Austria, for example, has no special provisions on this issue. This can create uncertainties in the interpretation and application of the mobility provisions across the Member States. Most Member States require a new hosting agreement in case the stay exceeds three months. However, the Netherlands and Poland do not require a new hosting agreement to be signed. Poland accepts the hosting agreement 
signed with research institution in another EU country if it includes information on the plan of conducting the research also in Poland. Upon applying for a residence permit to conduct research in Poland, foreigners present the agreement signed in another EU country. In the Netherlands, mobile researchers are exempt from the temporary residence permit (the so called MVV) and no new residence permit is required in case of stays of more than three months.

\section{The different forms of the registry of approved organisations}

145. According to the Directive, a research organisation that wishes to host a researcher must be approved by the Member State, and the Member State shall keep a registry of approved organisations. In most cases, rather than use an existing registry, the list was created specifically following transposition of the Directive. This was the case in Belgium, Italy, Sweden, Poland and Romania, for example. In Lithuania, no approval registry has been created and the researcher simply enters an employment contract directly with the research organisation.

146. Not all countries' registries cover all research organisations, so some researchers are not included. For example in Spain, some universities and research centres, public bodies dependent on state or independent communities and other Technology Centres/Centres of Technological Innovation Support are not obliged to seek approval. Researcher hosted fall outside of the scope of the Directive, and enter under a different work permit.

147. Countries which created registries did not extend these to other categories of permit or use the registry for other purposes. In Italy, for example, where transposition of the Researchers Directive meant that a registry was created (on 11/4/2008), it was not extended to other potential categories, such as professors under the quota exemption. When accelerated measures were later implemented for fast-track recruitment of high skilled workers, the registry played no role. However, the registry is the instrument of compliance, since registration requires institutions to respect the wage requirement (twice the minimum for the social benefit) but also guarantee to pay return expenses, cover the cost of health insurance, and commit to paying the costs of expulsion if the researcher overstays the permit, if these costs are incurred within six months of finishing the contract. Only institutions which can meet these requirements are able to register.

148. It is worth examining the Irish implementation of the Directive, since Ireland was not bound to transpose the Directive. Ireland transposed the directive as a "Hosting Agreement Scheme" (HAS), representing a clear identity for the permit. No other country gave the researcher permit its own brand name. Ireland's flows have been substantial relative to the size of the country: 1750 in the first six years, mostly issued to $\mathrm{PhD}$ researchers who are not yet independent. ${ }^{13}$ In universities, $10-30 \%$ of all researchers are employed under Hosting Agreements. Its implementation aimed at accelerating the procedure through a fast track and providing immediate family reunification. Ireland imposes a salary threshold ${ }^{14}$. In practice, the HAS allows research institutes to hire single third-country nationals at lower wages than would be possible under the Critical Skills Employment Permit; there is no evidence that the wage difference is what has made the HAS popular. It is run directly by the EURAXESS centre for Ireland. ${ }^{15}$ Hosting agreements were initially set at a maximum of three years, raised to five in 2009. From June 2012, researchers can apply for permanent residence ("Stamp 4") after just two years in Ireland. In addition to a registry of

\footnotetext{
13 This figure is much higher than the number of "first permits issued for remunerated activity - researchers" reported by Ireland to Eurostat, suggesting that not all HAS recipients are reported as researchers.

14 Point 3 on the IUA salary scale, or EUR 23181 from 2013, or 30000 if they have dependents

15

http://horizon-magazine.eu/sites/default/files/Attracting\%20Researchers\%20to\%20Ireland\%20\%20The\%20Impact\%20of\%20the\%20Scientific\%20Visa\%20May\%202013.pdf
} 
eligible institutions (more than 40 in 2013, although the seven universities accounted for four out of five agreements), EURAXESS created an electronic database of hosting agreements which can be consulted by immigration officials in Ireland and at foreign consulates. This is in contrast to most countries, where the agreement is a paper document shown to officials to obtain a visa and a permit. Family members may accompany researchers and have immediate access to the labour market. While family members' initial permit does not allow employment, they may receive an Employment/Dependent/Spouse work permit, on the basis of a job offer (excluding the domestic sector) without a labour market test. About one-fourth of the participants stated they would not have come to Ireland if there had not been a HAS. However, the main beneficiary appears to be host institutions rather than the researchers, since it greatly reduces the duration of procedures, reduces costs and simplifies hiring.

149. The Netherlands has also seen a sharp increase in the uptake of the researcher permit, especially by non-university bodies. The Dutch list of registered research institutes includes at least 30 private enterprises among the 110 registered sponsors. Universities, foundations and firms can use the researcher permit as an alternative to the national permit scheme for skilled migrants when the work is project-related, even when the salary paid to the researcher is below that necessary for other highly qualified schemes. Its introduction corresponded to the near-disappearance of the unpaid-research permit category.

Figure 8. The Researcher permit appears associated with higher inflows in the Netherlands

First permits issued annually for labour migrants and students, 2005-2014

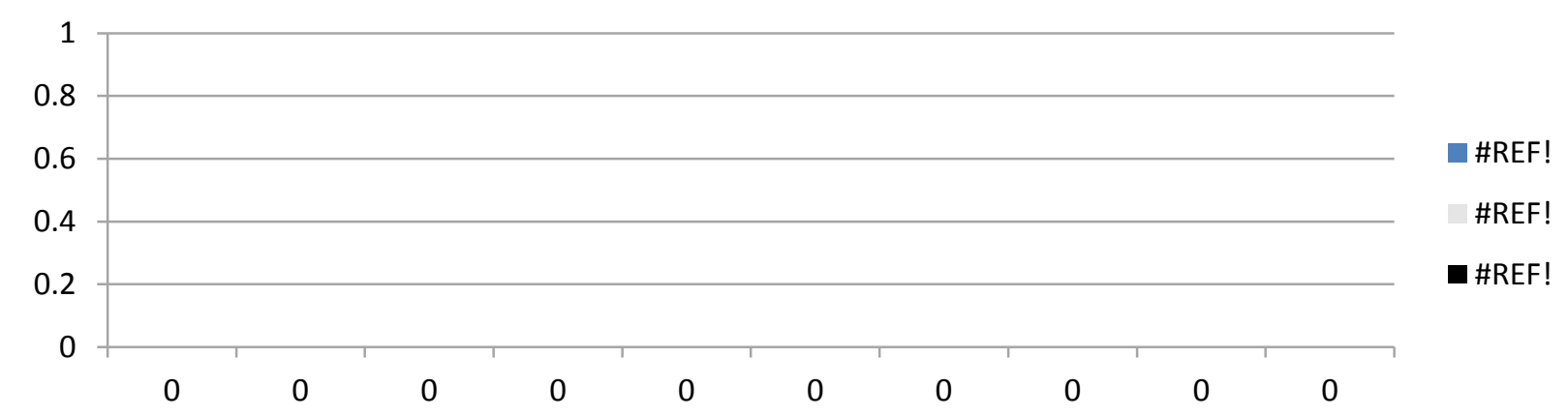

Source: OECD analysis of microdata from Dutch immigration authorities.

150. The Researchers Directive shifts decisions on admission, once taken by migration authorities, to research organisations. Overall, this has had a positive impact facilitating and increasing the access of TCN researchers to the EU (ICMPD 2011). The directive clearly favours recognised institutions. Considering the multitude of actors involved, the Directive would have an even wider impact if it was to define a uniform hosting agreement. Intra-European mobility might be favoured by having a standard hosting contract which the second country could easily interpret in the case of stays of less than three months. Moreover, Member States would enhance its effect by transposing the definitions of the Directive literally and linking the registries of approved research organisations to existing compliance or funding registries for research and academic institutions.

\section{The Blue Card: almost invariably a new permit category}

151. In comparison with the Students and Researchers directives, where all EU countries already had specific provisions in place prior to transposition, the EU Blue Card directive specifically creates a permit category for which national equivalents were not always pre-existent. Countries were faced with three 
overall legislative opportunities in transposing the Directive: substituting an existing category of permit; creating a new category alongside existing similar permits; or creating a new permit for which no functional equivalent existed.

152. One example of substitution of an existing permit was in Germany, one of the last countries to transpose the Blue Card into its national legislation (in August 2012). This occurred in the context of a general revision of the labour migration framework for skilled migrants, a complex framework focused on tertiary-educated foreigners with a job offer matching their qualifications. Germany took advantage of transposition to eliminate a permanent residence permit for high-salaried foreign workers - a permit which had seen little use, due to a high salary cap - to replace it with the EU Blue Card, a temporary renewable salary-based permit. While the EU Blue Card does not grant permanent residence, recipients may apply for permanent residence sooner than foreign workers holding other categories of work permit.

153. A second approach was that taken in Luxembourg. In 2008, Luxembourg introduced a permit for highly qualified workers. The criteria to qualify for this permit were not far from those of the future Blue Card. A salary threshold of three times the minimum social salary for an unskilled worker was set; this was close to the eventual Blue Card threshold. Further, the permit allowed for 5 years of experience to substitute for a tertiary degree, just as the Blue Card Directive permits. The transposition of the Blue Card was achieved by adjusting the 2008 permit criteria to incorporate elements of the Directive; the main change was the possibility to bring accompanying family rather than the requirement to wait one year. Similarly, Portugal had introduced a permit in 2007 for highly-skilled workers, and when it transposed the Blue Card directive, it left the existing permit on the books, mirroring the Blue Card threshold but adding an alternative calculation method for the salary threshold (three times the minimum social benefit amount).

154. A third approach was that taken in countries which opted for a minimal application of the directive, with the EU Blue Card little different from those already available for workers in general and highly qualified workers specifically. What distinguished the new Blue Card was thus principally the name and mobility provisions. Belgium, one example of this approach, implemented the Blue Card alongside its existing B Permit, albeit with a higher salary threshold.

155. A fourth approach can be seen in Italy, where no high-skilled permit existed, although a patchwork of exceptions to the volumes of admission allowed employers to recruit highly qualified foreign workers. When the volumes were introduced in 1998, employers complained that there were no places left for highly-qualified workers, leading to reserves in the volumes of admission set aside from 2002 for nurses and highly qualified workers. These later became exemptions. Nonetheless, workers receive a work permit with conditions identical to those of non-qualified contract workers. Following a procedure introduced in 2010, firms could sign a protocol with the Ministry of Interior. Similarly, in Bulgaria and Romania, no permit specifically targeting highly qualified workers existed.

156. In Lithuania, a general skill requirement was applied to all permits, although the threshold for skills was more flexible than that transposed as the Blue Card. The Blue Card thus created a distinct permit category. As Lithuania has historically taken a restrictive approach to labour migration, this approach extended to the transposition of the Blue Card.

157. Transposition also reflected the political process within the country, including the role of social partners. In Spain, the legislation was drafted by the Ministry of Labour, where the social partners are involved in the discussions and the trade unions have great weight in determining the final form of legislation. As transposition occurred at a time of severe economic contraction and spiralling unemployment, the legislation had a priority to protect the domestic labour market, and the narrowest possible application was made, not only by disallowing in-country issuance of the Blue Card, but also by 
going beyond the Directive to peg the salary threshold to mean salaries in the relevant occupation. The latter was done through internal circulars, rather than the legislation itself.

158. Where permits for highly qualified workers were already in place, the Blue Card may eventually supplant them. The Czech Republic transposed the Blue Card in 2011 while maintaining a national scheme for workers introduced in 2009, the "Green Card", which included a category for skilled workers (type A). Uptake of the Green Card was much lower than expected. While there were differences between the two schemes, the Czech Republic eliminated the Green Card in 2014, along with a reform of its general work permit framework, leaving the Blue Card as the only scheme targeting highly qualified workers. In France, the first country to transpose the Directive, the permit was introduced alongside two other permits for qualified workers: the general contract worker permit, and the "skills and talents" permit, without a particular effort to encourage applicants to use the Blue Card. The French EU Blue Card is likely to evolve in the future: a 2014 proposed law would absorb the Blue Card as a subcategory of a new multi-year permit, with more favourable conditions than under the current transposition, called the "Talents Passport". The reform process is still underway.

159. A number of countries already had permits for highly qualified workers which they did not suppress or replace with the EU Blue Card. Finland, for example, transposed the Directive in such a way as to not interfere with an existing specialists permit. Most of the qualified workers coming to Finland come for periods of less than one year, or have salaries below the Blue Card threshold, so the existing framework was left in place to cover these categories. The Blue Card, transposed in 2012, did not figure in the 2020 Migration Strategy published the next year (Finnish Ministry of Interior, 2013). ${ }^{16}$

160. In the case of the Netherlands, a complex existing system for highly qualified employees was left intact and preserved as the main channel of entry. The framework, dating from 2004, is based on an expensive and increasingly cumbersome employer sponsorship process, after which recruitment of individual workers by these employers is rapid and simple, as long as they meet a salary threshold. The Blue Card was implemented with a higher salary threshold, more than 25\% higher than the threshold for the highest-bracket salary of skilled migrants. The Blue Card procedures are more complex than for the national scheme, although this is not the intention of the Dutch government, which is working to align them as closely as possible. Yet post-transposition policy discussion has largely neglected the Blue Card. The social partners' joint council that advises on issues of labour migration, the Sociaal-Economische Raad (SER), receives considerable attention from government and parliament. It produced two reports on labour migration, in 2013 and 2014, neither of which mentioned the Blue Card, nor did the government cabinet's 2014 response to the SER report.

161. In Austria, plans to introduce an attractive permit for highly qualified foreign workers began in 2008, with the Blue Card discussion in the background, and were implemented in 2011, at the same time as transposition of the Blue Card Directive. The national scheme, the Red-White-Red Card, comprises in its scope the same highly qualified workers as the Blue Card, but with more flexible criteria under different points-based systems and five different target groups. The total inflow of qualified foreign workers to Austria did not substantially change after introduction of the new scheme, but new permits have been largely under the national scheme, and certain optional elements of the Blue Card (the five-year experience clause, for example) were not taken up, to favour the national scheme. Further, the Austrian system encourages Blue Card holders to shift after one year or upon first renewal into the more favourable national scheme, the Red-White-Red-Plus card, which grants total labour market mobility.

In fact, after the Blue Card has been introduced and consolidated in legislation, it does not always appear in national strategies. Romania's 2011-2014 Migration Strategy for example, identified the Blue Card as an action area, although none of the annual plans which followed brought this idea forward, and the 20152018 Strategy dropped any mention of highly qualified migrants. 
162. In one case, transposition occurred while policy-makers put little stock in the instrument. Even as the Slovak Republic was transposing the Blue Card, it was making plans to create a "Slovak Card" explicitly as a "modification of the Blue Card" (Government of Slovak Republic, 2011). This Slovak Card remained part of the Slovak government objectives in the area of economic migration through 2014. The Slovak Card was meant to attract and retain skilled migrants, with a likely application to more candidates than the Blue Card, of which only a handful have been issued. The Slovak Card was however never developed, and disappeared from policy development in 2015.

163. Spain, which had taken a minimal transposition for the reasons discussed above, re-examined its policy for highly qualified migration in $2012 .{ }^{17}$ The Blue Card was judged as having an excessively rigid definition of highly qualified professionals, and excessively high wage limits, which especially penalised young graduates. Further, since the shortage list had dwindled due to the employment crisis, most qualified jobs were subject to the LMT. As negotiating changes to the Blue Card would have involved the same process in the Ministry of Labour as its introduction, there was little prospect of amending the legislation to ease access to the Blue Card by using a single national salary threshold, opening the experience class or allowing in-country issuance. It was the Ministry of Economy, which has fewer constraints in developing a new legislative package, which introduced a national scheme through an economic law with the aim to foster the internationalisation of Spanish companies. The law thus had an explicit focus on the needs of businesses. ${ }^{18}$ The groups targeted included management or highly qualified staff of large businesses, SMEs in strategic sectors, or in projects of general interest - based on the firm and job characteristics, rather than those of the worker. The match between worker and job is assessed on a case-by-case basis, covering tasks, qualification, salary and experience. An additional category focused on worker characteristics: graduates of universities and prestigious business schools. These categories overlapped with the Blue Card but were based on characteristics - the employer, the project or the university of study - which are not contemplated under the Blue Card.

\section{Volumes of Admission and exemptions}

164. There are two principal general restrictions on labour migration which are allowed to extend to Blue Card applicants: the imposition of caps (or "volumes of admission") and the labour market test.

165. There are only a few EU countries covered by the Blue Card directive which rely on volumes of admission for their labour migration management system (see Table 1): Italy, Greece, Estonia and Hungary. Italy is the country where labour migration is most determined by these volumes of admission, but Italy exempts all skilled workers, including Blue Card holders, from the limits. Greece also uses biannual volumes of admission - currently set at zero - for region and occupation. This applies to all work permits, including for highly qualified labour. A Joint Ministerial Decision, issued in the last quarter of every second year determines the maximum number of job posts for highly qualified labour that can be filled in by citizens of third countries (using the Blue Card). In 2014, this was zero.

This assessment was conducted by a multidisciplinary team composed not only of the traditional actors in immigration policy (Ministry of Employment and Social Security, Ministry of the Interior, Ministry of Foreign Affairs and Co-operation) but also the Ministry of Employment and Competitiveness. The latter introduced a trade slant to the analysis and played a key role in identifying the barriers posed by immigration policy to the attraction of investors, entrepreneurs and highly qualified migrants.

Law 14/2013, Article 1 provides a declaration of intent: "This Act seeks to support entrepreneurs and entrepreneurial activity, foster their development, growth and internationalisation, and promote entrepreneurial culture and an environment favourable to economic activity, both in the initial period of business start-up and in its subsequent development, growth and internationalisation". 
166. Estonia and Hungary set annual volumes of admission, but these have not affected actual issuance of work permits, as they have been set high enough that they have not been reached. In both cases the Blue Card is subject to general volumes of admission. The transposition of the Directive in Cyprus ${ }^{19,20}$, unlike elsewhere, applied specific volumes of admission to Blue Cards rather than to overall labour migration. These volumes were set at zero, obviating any uptake of the permit and leaving highly qualified applicants to use the standard labour market tested route.

\section{Labour market tests and exemptions}

167. The Labour Market Test used in many EU countries in general labour migration schemes varies in degree of strictness, from nominal tests to real tests. Even where the LMT is difficult to pass, this generally affects employment in lower pay and less qualified employment where local candidates are more numerous. The strong role of the public employment services in many LMT vacancy requirements and approval (see Table A.1) also makes the LMT less likely to hinder recruitment of the highly qualified, since PES generally handle less qualified employment in most EU countries.

168. In no cases was a LMT introduced to regulate Blue Cards where no LMT was already in place for labour migration schemes. A number of countries exempt Blue Card applicants from the LMT which applies to general work permit schemes. Germany exempts all jobs with salaries above the national EU Blue Card limit from the LMT, regardless of whether an EU Blue Card is issued.

169. Where the LMT represents a real obstacle to labour migration, its extension to the Blue Card can affect uptake. Austria applies a LMT to both the Blue Card and its other work permit schemes, including the Red-White-Red card (except for very highly skilled migrants under the RWR scheme). In France, the LMT is one of the main challenges for labour migrants, and is applied to all foreign workers under the general scheme with the exception of those employed in shortage list occupations. Blue Card applicants are exempt from the LMT. In Hungary, the general LMT is extended to Blue Card applications, although other factors prevent uptake of the permit.

170. Lithuania applies a labour market test to all renewals, including first renewals within two years of Blue Cards, unless the Blue Card salary is above three times the national average.

\section{How does the Blue Card compete with national schemes?}

171. Relative to existing schemes, criteria for the Blue Card which may make it less competitive are the minimum one-year contract duration; the salary threshold; and the need to demonstrate qualifications, either academic or professional.

172. Advantages of the Blue Card which can only be provided by EU-level legislation are that it provides a possibility for mobility within the internal market without requiring exit to apply for a visa for the next country of employment, and to accumulate periods of residence for long term residence status.

19 Note by Turkey: The information in this document with reference to "Cyprus" relates to the southern part of the Island. There is no single authority representing both Turkish and Greek Cypriot people on the Island. Turkey recognises the Turkish Republic of Northern Cyprus (TRNC). Until a lasting and equitable solution is found within the context of the United Nations, Turkey shall preserve its position concerning the "Cyprus issue".

20. Note by all the European Union Member States of the OECD and the European Union: The Republic of Cyprus is recognised by all members of the United Nations with the exception of Turkey. The information in this document relates to the area under the effective control of the Government of the Republic of Cyprus. 
Nonetheless, the Blue Card Directive does establish a number of characteristics which could be more favourable relative to national schemes, principally: maximum processing time; accompanying family and immediate labour market access for family members; job-search periods in case of unemployment.

173. The EU Blue Card has clearly created a more favourable permit category in a number of EU countries which had no special category for highly qualified workers. These are Estonia, Bulgaria, Hungary, Latvia, Lithuania, Poland, Romania, Slovenia, and the Slovak Republic. In all these countries, there were only general work permit programmes prior to implementation of the Blue Card. While the EU Blue Card provides more favourable conditions than the standard work permit in these countries for persons meeting the Blue Card criteria (salary, education or qualification, one-year job contract in highly qualified occupation), these same situations also allow alternative permits which require demonstrating fewer qualifications.

174. The Blue Card has struggled to compete with national schemes in countries where the national schemes are simpler to access due to fewer documentation requirements, such as France, the Netherlands, and Belgium, or where the general framework is very open, such as Sweden.

\section{Faster processing time}

175. Art 11.1 of the Directive sets a 90-day maximum processing time, although this requires a "complete application", which may include documents which require additional time to assemble. The transposition of the Single Permit Directive also aims to ensure a statutory maximum processing time for work permits covered under the directive. The 90-day limit for processing complete applications has not meant shorter times in the countries of transposition, as previous processing times were already less than 90 days (OECD, 2013). In a number of countries, mandated processing times are shorter for general permits (e.g., 60 days in Italy). In Spain, other work permit applications are automatically rejected if no response is issued in 90 days, while the Blue Card application is automatically approved.

176. Due to documentation requirements, Blue Cards may take more time to evaluate and process than other work permits. This is the case in Sweden, where standard work permit applications are handled in less than a month, and Blue Cards generally take longer.

177. National permit requirements may apply to other permits. The Netherlands exempts mobile Blue Card holders from the requirement to obtain an MVV temporary permit for entry, saving time for entry.

178. Lithuania set its processing time limit according to the income level of the applicant. At twice the benchmark salary, processing must take place within 60 days; at three times the benchmark, it must be completed in 30 days.

179. Beyond the conditions established by the Directive, a number of countries have implemented fast-track processing for permits which include - but are not limited to - the EU Blue Card. Spain, for example, provides fast-track processing for investors, ICTs, highly-qualified executives and MBAs, and Blue Card applicants. Italy allows employers who have signed protocols with the Ministry of Interior (similar to approved sponsorship) to skip the standard authorisation procedure. Lithuania allows applicants to pay double the standard fee to halve processing time. France has a single window for fast-track processing, which cannot be used for the standard work permit, but is available for Blue Card applicants as well as ICTs and applicants for the little-used Skills and Talents permit. Bulgaria has committed to a 7-day turnaround for Blue Card issuance by the Migration Directorate, although the Employment Agency previously has 15 days to approve the work permit prior to this.

180. It is important to distinguish between initial issuances of permits to foreign workers arriving from abroad, and those issued to foreigners already in the country under another status (principally, employment 
or study). In the case of the first, where the worker holds a job offer from an employer, both employer and employee usually have an interest in the fastest and simplest procedure to begin work immediately. As delays can occur at many points in the process, Blue Card requirements for recognition of experience and qualifications can slow down the application and push applicants towards procedures where recognition is not required.

181. This may explain why a large share of first Blue Cards has been for status change. For former students, national degrees obviate the recognition process. For workers already in employment, there is no urgency for obtaining the Blue Card.

\section{Potentially restrictive application of the salary threshold}

182. The Blue Card salary threshold is meant to limit eligibility to highly qualified workers, with a productivity premium over the average justifying the higher salary. Setting a threshold for experience was subject to debate during the negotiation, with the Commission's initial proposal of three times the average salary decreased to 1.5 in the version discussed by the Home Affairs Committee of the European Parliament, which in turn requested a threshold of 1.7 in November $2008 .{ }^{21}$ In none of these discussions was the reference figure clearly defined, nor was the proposed threshold examined to see exactly where it falls in the salary distribution at the European level or at national level.

183. Table 1 shows the different mean salary according to different estimation methods. The first method is based on national accounts and simply divides wages by the number of employees. The second column reports the OECD full-time equivalent salary, calculated by taking the ratio of the average hours worked by employees working at least 30 hours weekly to the total average hours worked, and applying it to the first ratio. The third column is based on the EU-SILC and German SOEP and includes total gross annual wage and bonus income for employees working more than 35 hours weekly. Adjusting for part-time work has a particularly strong effect in countries where part time work is very frequent, such as the Netherlands. EU-SILC tends to produce figures which are close to the OECD estimates, with several outliers.

21 Consultation report drafted by Ewa Klamt (EPP-ED, DE) in co-operation with the Employment Committee www.europarl.europa.eu/sides/getDoc.do?type=IMPRESS\&reference=20081103IPR41239\&language=EN 
DELSA/ELSA/WD/SEM(2016)6

Table 2. The mean salary is very different according to the reference values used

Mean annual income in selected EU countries according to national accounts and survey data, 2013, Euro

\begin{tabular}{|c|c|c|c|c|c|}
\hline Country & $\begin{array}{c}\text { Eurostat National } \\
\text { Accounts/Employees }\end{array}$ & $\begin{array}{c}\text { OECD Full-time } \\
\text { equivalent }\end{array}$ & $\begin{array}{l}\text { EU-SILC employed } \\
\text { more than } 35 \text { hours }\end{array}$ & Ratio b/a & Ratio c/b \\
\hline & (a) & (b) & (c) & & \\
\hline AT & 34800 & 39100 & 41400 & 1.12 & 1.06 \\
\hline BE & 38400 & 42400 & 41300 & 1.10 & 0.97 \\
\hline CZ & 11400 & 11600 & 11100 & 1.02 & 0.96 \\
\hline DE & 30800 & 35700 & 39200 & 1.16 & 1.10 \\
\hline EE & 11800 & 12200 & 10100 & 1.03 & 0.83 \\
\hline $\mathrm{EL}$ & 17000 & 18600 & 18600 & 1.09 & 1.00 \\
\hline ES & 25200 & 27000 & 24000 & 1.07 & 0.89 \\
\hline $\mathrm{FI}$ & 36900 & 39900 & 41500 & 1.08 & 1.04 \\
\hline $\mathrm{FR}$ & 33100 & 35600 & 30300 & 1.08 & 0.85 \\
\hline $\mathrm{HU}$ & 9500 & 10200 & 6800 & 1.07 & 0.67 \\
\hline IT & 25700 & 28400 & 28500 & 1.11 & 1.00 \\
\hline LU & 54100 & 58500 & 55100 & 1.08 & 0.94 \\
\hline $\mathrm{NL}$ & 34900 & 45300 & 52000 & 1.30 & 1.15 \\
\hline $\mathrm{PL}$ & 10200 & 10500 & 8900 & 1.03 & 0.85 \\
\hline PT & 15900 & 15900 & 14200 & 1.00 & 0.90 \\
\hline SE & 39500 & 42800 & 41600 & 1.08 & 0.97 \\
\hline $\mathrm{SI}$ & 20900 & 22000 & 20000 & 1.05 & 0.91 \\
\hline SK & 11400 & 11700 & 8700 & 1.03 & 0.74 \\
\hline DK & 47900 & 54400 & 56100 & 1.14 & 1.03 \\
\hline $\mathrm{IE}$ & 40500 & 49700 & 45400 & 1.23 & 0.91 \\
\hline UK & 31800 & 38000 & 35700 & 1.19 & 0.94 \\
\hline
\end{tabular}

Source: Eurostat; OECD Employment Database, EU-SILC, GSOEP.

184. The freedom to use different reference values has translated into barriers which are quite different from one country to another. In practice, most EU countries have applied a salary threshold which is close to (or below) the minimum specified in the Directive (see Figure 3). Romania has very low average salaries and set its threshold at four times the national average; Lithuania at twice the average. Belgium applies a salary threshold about $30 \%$ higher than it applies for its standard B work permit; this is the main reason why the standard B permit is more popular. Finland, likewise, applies a threshold which is $60 \%$ higher than the threshold for specialists. The threshold in Estonia is higher for the Blue Card than for the national permit (set at 1.24 times the average salary), although specialists are generally subject to a higher threshold ( 2 times the average).

185. Since salary distributions vary across EU countries, the level of restrictiveness (the share of employees earning above the threshold) varies much more widely than the difference between the reported mean and the national threshold. Figure 9 shows the earnings dispersion (ratio of the top to middle decile) and incidence of high pay (share of workers earning more than 1.5 times median earnings) for EU countries covered by the Blue Card Directive. In Italy, only $11 \%$ of workers earn more than the 1.5 threshold, while in Portugal, $28 \%$ do. This indicates that application of a salary criterion would have a more restrictive effect in Italy than in Portugal. Nordic countries with compressed wage structures have more narrow distributions, so application of a 1.5 multiple places the threshold in a higher decile of income. In Sweden and Finland, the only the top decile of workers earns more than 1.5 times the median decile. Most countries index their Blue Card thresholds to average, rather than median, national indicators. 
Figure 9. The distribution of earnings is not standard across EU countries

Earnings dispersion and incidence of high pay, 2012

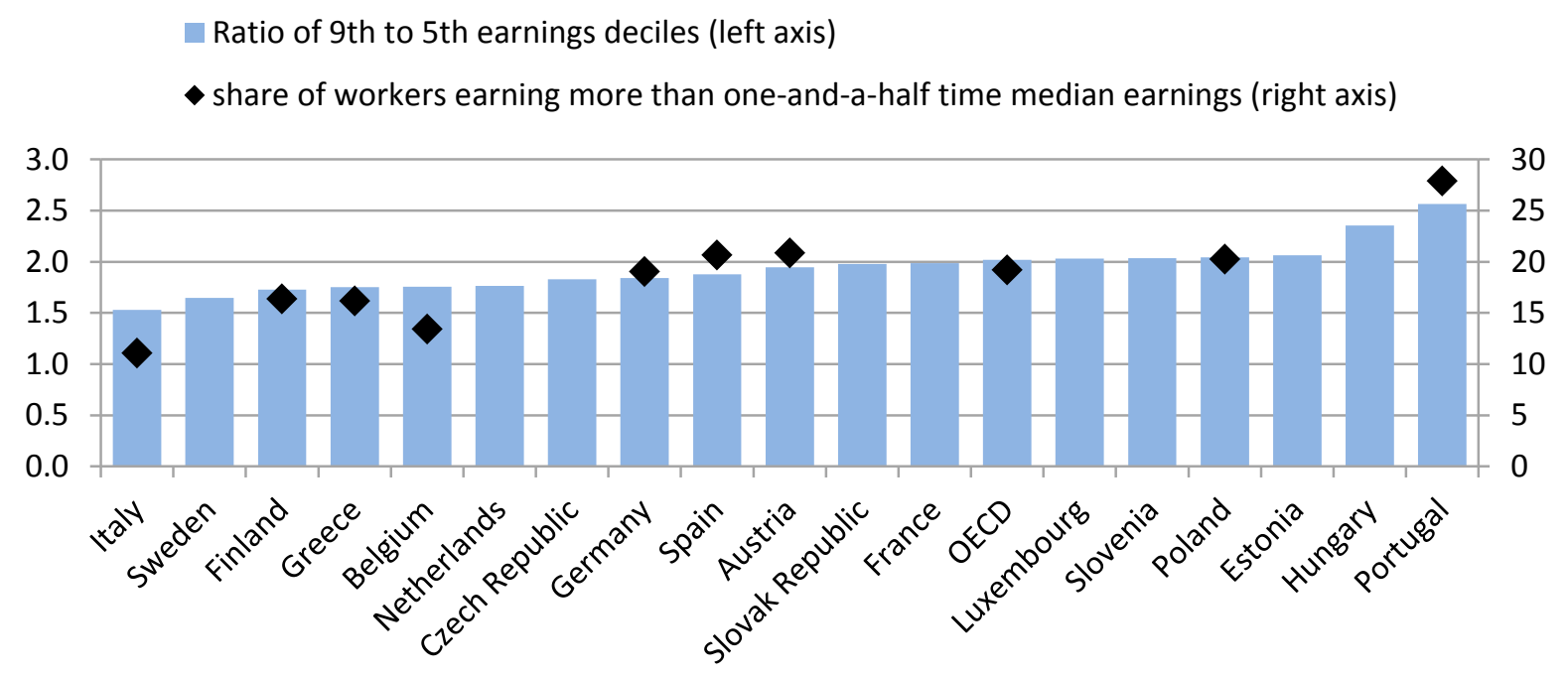

Source: OECD Employment database

\section{Box 1. Using the EU SILC to determine salary distributions}

The EU Statistics on Income and Living Conditions is a longitudinal cross sectional survey conducted in EU countries under co-ordination by Eurostat. It contains information on characteristics of employees, their employment and their income. It allows examination of the distribution of salaries. In this analysis, the figure is the gross annual income of the full-time employed (for the EU-SILC, part-time workers who work more than 35h per week were also included). In EU SILC, the highly educated group is based on ISCED 19975 and 6, and includes level 5B (first stage of tertiary education, short practical/technical/occupationally specific programmes leading to professional qualifications). This means that the EU-SILC "highly educated" includes individuals who have not finished tertiary education. EU-wide, $72 \%$ of tertiary educated have 5 a and 6 levels, which correspond to completed tertiary education. Still, in some EU countries, as much as half the "tertiary educated" population in EU-SILC can be assumed to be ISCED 5b. The analyses presented here should be considered therefore as conservative (i.e., they suggest that fewer of the "highly educated" meet the threshold than is true, as ISCED $5 \mathrm{~b}$ is associated with lower income than ISCED $5 \mathrm{a}$ and 6 . For the analysis of specific education and age group, dataset 2011 to 2013 were pooled to secure reliability thresholds of Eurostat. Except for that group, the latest available data - 2013 - were used. Observations with zero income are dropped, even if they work in full-time basis. The mean and median annual income of total observations are produced on this basis, and the $1.5^{\star}$ mean and $1.5^{\star}$ median were applied to all groups with different characteristics as standards. Finally, the Blue Card thresholds and the national thresholds for each country refer to the value set in 2014 . As data for Germany were not available in SILC, the GSOEP was used instead. 
186. Using survey data from the EU SILC (see box), it is possible to evaluate the share of the employed population already earning more than the reference threshold in each EU country. Figure 10 shows the results. Overall, in most countries, less than $15 \%$ of the population earns more than the Blue Card threshold. In several countries. If the median or mean (calculated within SILC observations) are used, the range is less variable.

\section{Figure 10. Only a small fraction of the total employed population earns more than the Blue Card threshold}

Share of full-time employed whose salary is above $1.5 \times$ mean, $1.5^{\star} \times$ median, and actual threshold (Blue Card and other national schemes). Income data 2011-2013; thresholds in 2014

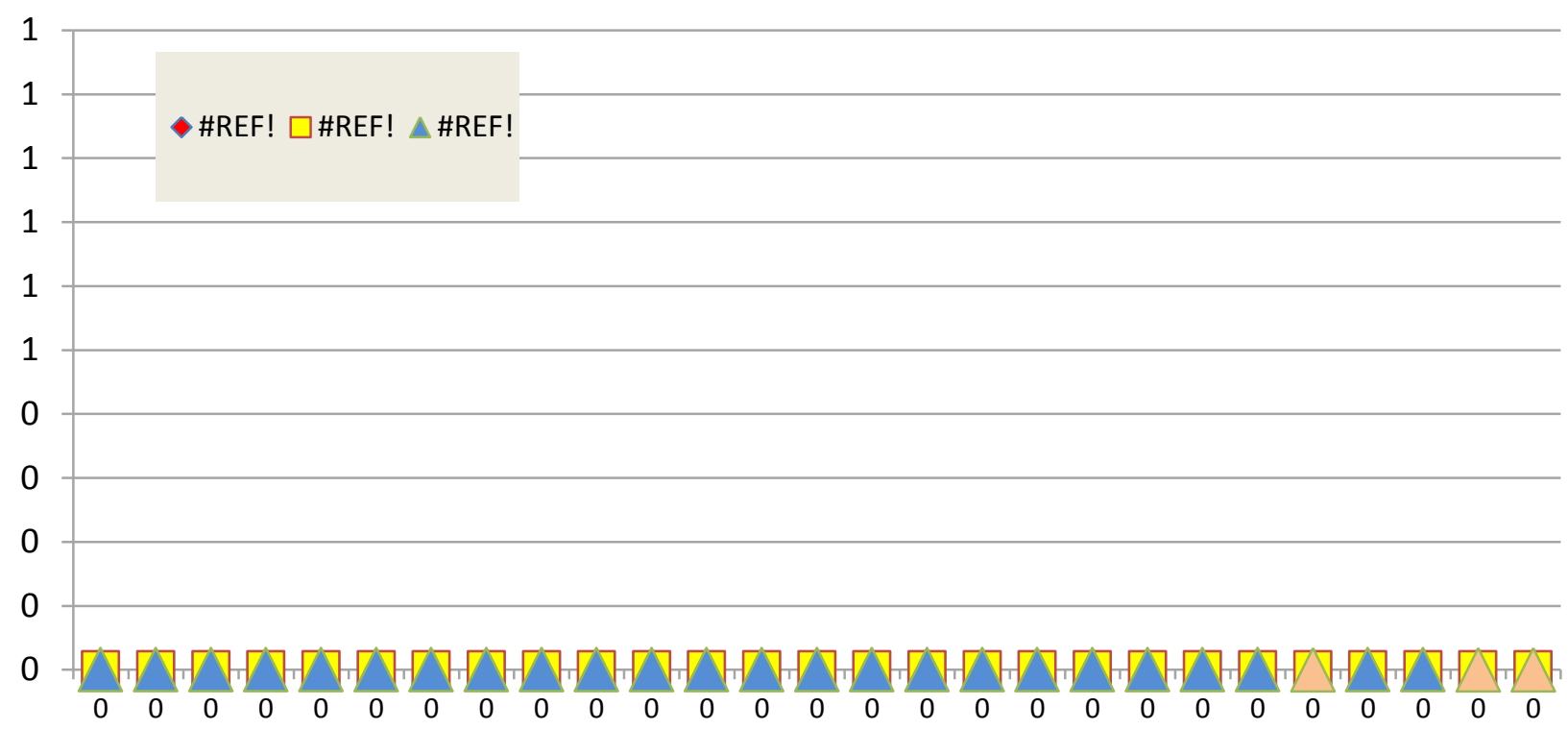

Source: EU-SILC, 2010, including gross earnings and annual bonuses and allowances not paid at each pay period, except for Germany, SOEP, 2010, gross earnings only, full time or at least 35 hours weekly employment.

187. A more exact means of examining the Blue Card salary threshold is to examine the share of highly educated national workers earning more than the threshold. Figure 11 shows the share of full-time employed earning more than the Blue Card threshold, by educational level. Some countries are extremely restrictive even for the highly educated. In Lithuania and Romania, this is partly due to the thresholds being set at multiples above the statutory minimum. In Sweden and Finland, where about 20-25\% of tertiary educated meet the threshold, it reflects wage compression. Most countries have thresholds above which about $40-50 \%$ of tertiary-educated workers are placed. Portugal and Italy have thresholds which are met by more than $80 \%$ of national tertiary-educated workers. In a few countries - notably Italy, but also to a lesser extent Luxembourg - a significant fraction of the medium-educated earn enough to meet the national threshold. 
Figure 11. The Blue Card threshold is far less restrictive for higher-educated workers

Share of gross full-time earnings above national Blue Card threshold, by educational groups tertiary educated, selected EU countries, 2010

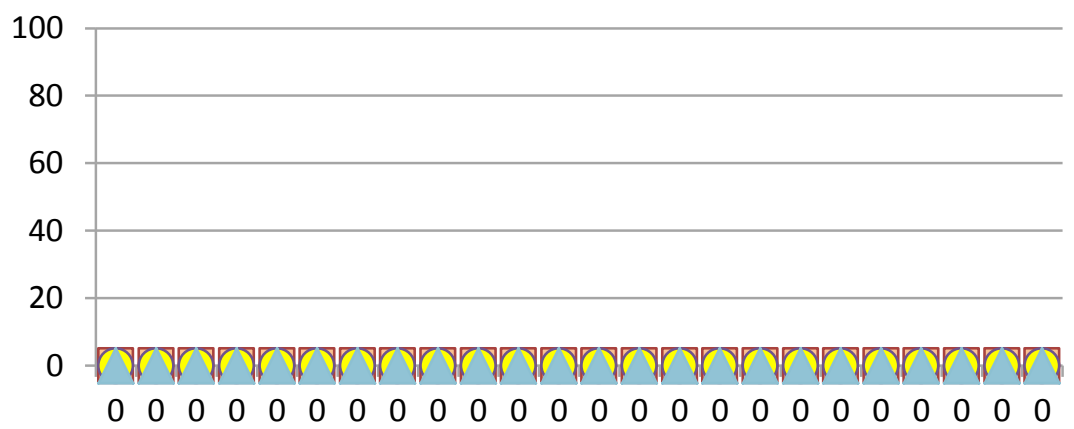

\author{
\#REF! \#REF! \#REF! \#REF! \#REF \\ \#REF! \#REF! \\ O \#REF! \#REF! \#REF! \#REF! \#REF! \\ \#REF! \#REF! \\ $\triangle$ \#REF! \#REF! \#REF! \#REF! \#REF! \\ \#REF! \#REF!
}

Source: EU-SILC, 2010, including gross earnings and annual bonuses and allowances not paid at each pay period, except for Germany, SOEP, 2010, gross earnings only, full time or at least 35 hours weekly employment. Tertiary educated refers to ISCED 1997 levels $5 \mathrm{~b}, 5 \mathrm{a}$ and 6 . DE-low refers to the lower threshold.

188. Another area where the salary threshold can be restrictive is for youth. In France, the salary requirement for the Blue Card ( $€ 52750)$ is set above the usual starting wages of new graduates. As newly graduated international students are a main channel of workers in France, most end up in the pre-existing work permit. ${ }^{22}$ Figure 12 shows how the Blue Card is restrictive for earnings of new graduates. In most countries, only a small fraction (2-7\%) of tertiary-educated young people age 25-29 earn above the Blue Card threshold, even when a much larger share of the total tertiary-educated population is above the threshold. Italy and Portugal are favourable for new graduates due to the low thresholds. Luxembourg, which issues a relatively large number of Blue Cards, is also favourable due to the higher salaries of tertiary-educated youth. Nonetheless, overall the picture is of a restrictive threshold.

Figure 12. It is much harder for young educated people to meet Blue Card thresholds

Share of gross full-time earnings above national Blue Card threshold, tertiary educated total and tertiary educated, age 25-29, selected EU countries, 2010

- Tertiary Educated $\quad$ Tertiary educated age 25-29

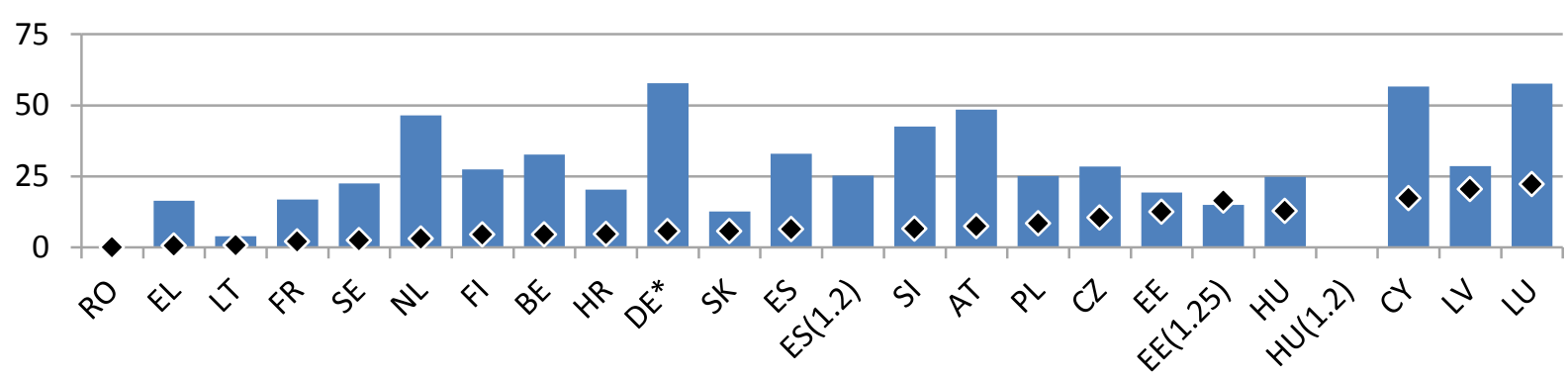

Source: EU-SILC, 2010

22 The "Skills and Competences" permit, which could also provide an alternative route, does not require a job offer but is based on a strict panel review, in which low salaries would likely have a negative effect on approval. 
189. The analysis above relies on survey data to examine income distributions by characteristics of the individual (age and education). This detailed information can be used at a national level to establish thresholds. Spain applies a threshold relative to the specific occupation (three-digit ISCO classification), which translates into a much higher threshold than in other countries, since the average salary of tertiarylevel occupations ( $€ 53200$ for ISCO group 1 and $€ 35000$ for ISCO group 2) is much higher than the average salary for all occupations ( $€ 22700$ in 2012). Spain, however, also makes the broadest possible use of the lower salary threshold, applying the 1.2 multiple to all ISCO group 1 and 2 occupations. In both cases, Spain uses survey rather than administrative data to determine salary levels.

190. The lower salary thresholds make it much easier to qualify for the countries where these are used. Figure 13 compares the share of employed earning above the relevant thresholds overall and in shortage occupations in the five EU countries which use the shortage list. As salaries are higher within shortage occupations, and the threshold lower, a larger share of the employed qualify. The exception is Spain, where the benchmark moves with the occupation, and therefore is actually harder to reach within these occupations.

Figure 13. It is much easier to qualify for shortage list occupations

Share of high-educated full-time employed earning above the regular and shortage threshold.

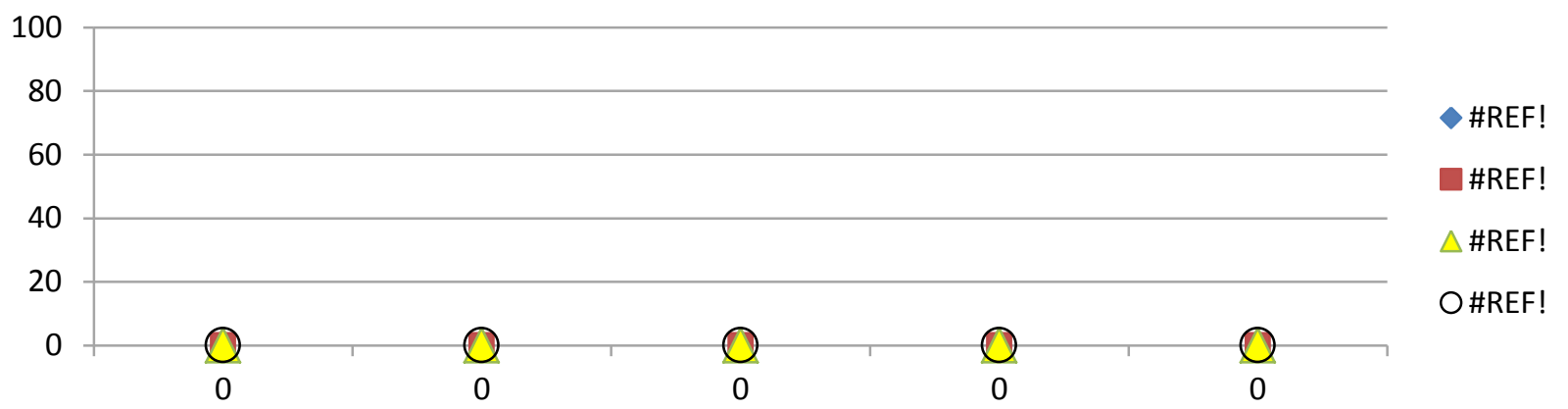

Source: EU-SILC, 2010, including gross earnings and annual bonuses and allowances not paid at each pay period, except for Germany, SOEP, 2010, gross earnings only, full time or at least 35 hours weekly employment. Tertiary educated refers to ISCED 1997 levels 5b, 5a and 6.

191. The distribution of income from EU-SILC is presented in the Annex in figures 14 and 15. The distribution of salaries looks very different from one EU country to another. In countries where incomes are concentrated (close mean and median), small shifts in the threshold translate into bigger changes in eligibility. In countries with long flat tails, shifting the threshold makes less difference.

192. The most effective way to evaluate whether the salary threshold is restrictive would be to look at the actual salary distribution of recipients of the Blue Card (and of national permits). This is the approach taken by the UK Migration Advisory Committee, for example, in evaluating its salary scheme (2015), and by analyses of the Dutch national scheme (OECD, 2016). Comparisons allow analysis of whether the threshold has a strong clustering effect or if the salaries of actual recipients are well above the threshold. However, most EU countries do not record the salary information of recipients of work permits, making this analysis impossible at the national level, let alone at the European level.

\section{Exemptions from the Labour Market Test}

193. Although art. 8(2) of the Blue Card Directive allows a labour market test to be applied, exemptions often apply (table 2). Potentially onerous labour market tests can be avoided in France and 
Luxembourg. Italy imposed the standard LMT on Blue Card applicants in its 2012 transposition, but simplified the LMT in 2013 for all work permits, requiring only that employers consult the PES prior to requesting authorisation.

Table 3. Labour Market Tests applying to national schemes and EU Blue Cards

\begin{tabular}{|c|c|c|c|}
\hline Country & EU Blue Card & $\begin{array}{l}\text { National Scheme for } \\
\text { highly qualified }\end{array}$ & $\begin{array}{l}\text { General National } \\
\text { Scheme }\end{array}$ \\
\hline Austria & LMT (most cases) & LMT (some cases) & LMT \\
\hline Belgium & Allowed, but not applied & No LMT & n.a. \\
\hline Bulgaria & $\begin{array}{l}\text { LMT (except for shortage } \\
\text { occupations from 2016) }\end{array}$ & n.a. & LMT \\
\hline Czech Republic & LMT & n.a. & LMT \\
\hline Germany & No LMT & No LMT & LMT \\
\hline Greece & LMT & n.a. & LMT \\
\hline Hungary & LMT & n.a. & LMT \\
\hline Finland & No LMT & No LMT & LMT \\
\hline France & No LMT & LMT & n.a. \\
\hline Estonia & LMT & LMT (some exceptions) & LMT \\
\hline Italy & $\begin{array}{l}\text { LMT, except for pre- } \\
\text { approved employers }\end{array}$ & $\begin{array}{l}\text { LMT, except for pre- } \\
\text { approved employers }\end{array}$ & LMT \\
\hline Latvia & LMT & n.a. & LMT \\
\hline Lithuania & $\begin{array}{l}\text { No } L M T \text {, unless salary is }<3 x \\
\text { average }\end{array}$ & LMT & n.a. \\
\hline Luxembourg & No LMT & n.a. & LMT \\
\hline Netherlands & No LMT & No LMT & LMT \\
\hline Poland & LMT & n.a. & LMT \\
\hline Romania & No LMT & n.a. & LMT \\
\hline Sweden & LMT & n.a. & LMT \\
\hline Slovenia & LMT & n.a. & LMT \\
\hline Slovak Republic & LMT & n.a. & LMT \\
\hline Spain & LMT & No LMT & n.a. \\
\hline
\end{tabular}

194. The actual content of the labour market test varies according to national practices, but few countries use a substantially different labour market test for Blue Card holders than for other work permits. One example is the Czech Republic uses separate registries for vacancies by employers who wish to recruit foreign workers under the Blue Card and under the general scheme, although vacancies can be listed in both. This means that employers must decide before posting a vacancy that they are willing to recruit a Blue Card employee, or must list the vacancy after a candidate requests sponsorship for a Blue Card. All employer changes are subject to the LMT.

195. The LMT may also be dropped if it is seen as an obstacle to uptake of the Blue Card. Bulgaria, as part of efforts to make the Blue Card more attractive, proposed in 2015 to lift the labour market test for shortage occupations with a higher salary level, although this proposal is under discussion.

196. LMT refusal rates are generally low for highly-qualified and high salary employment (OECD, 2013), so that the LMT is more likely to represent a delay in the procedure than a refusal for employer requests. 


\section{Exemptions from employer sponsorship schemes}

197. The employer sponsorship requirement in the Netherlands does not apply to the Blue Card scheme, although employers may use it voluntarily. If they do so, processing times for sponsors are faster: two weeks instead of 90 days. In Italy, a sponsorship scheme introduced in 2009 for executives and other highly qualified employees allows employers to sign a protocol with the Ministry of Interior, to skip the mandatory vacancy listing and approval process. This approach is allowed for Blue Card issuance, following the same procedure. Sponsorship procedures, as noted above, favour larger enterprises planning to hire multiple highly qualified workers.

\section{More favourable family reunification conditions}

198. One of the main benefits of the EU Blue Card relative to other schemes is that it allows for accompanying family members. Most EU countries (Italy, Spain, Luxembourg) do not allow accompanying family for most work permits, and impose a one year period before workers can sponsor family members. Processing times for family members are faster in Belgium for Blue Card holders (4 months) than for B permit holders (6 months), and the housing requirements are slightly less. In Lithuania, at least two years residence, and the prospect of permanent residence, are required before family reunification is allowed. For all these countries, this makes the Blue Card attractive to applicants with family who wish to bring them in the first year. However, national permits for highly qualified may allow accompanying family (e.g., in Spain for the Highly Qualified permits).

199. Some countries, such as Sweden and the Czech Republic, or the Netherlands and Austria for skilled workers, allow accompanying family for all labour migrants meeting basic sponsorship criteria, making the Blue Card less competitive. The Czech Republic eliminated its Green Card, which didn't grant the right to work to skilled migrants' dependents, in favour of the Blue Card. Austria exempts family members of Blue Card holders from the basic German language requirement. Family members of Blue Card holders hold a permit which can be renewed independently if income levels qualify; the same benefits apply to the national scheme.

200. Full immediate labour market access for family members is a significant benefit, although most countries grant this already, and in any case the Family Reunification Directive requires that labour market access be granted after one year to family members.

201. Facilitations for family members need to be compared with the conditions offered under other permits. Finland, where the national scheme remains the principal channel for reasons indicated above, skilled workers may see the requirements eased for family reunification. Finland looks at the situation of individual migrants in applying salary requirements for family reunification, based on local cost of living and family size. Further, since "reducing the income requirement on a case-by-case basis for workers' family members is one way of facilitating labour migration to Finland" (Finnish Ministry of Interior, 2013), this approach allows more flexibility in the national scheme.

\section{More favourable access to permanent residence}

202. The EU Blue Card allows countries to sum prior residence periods in other EU countries, holding a Blue Card, to qualify for long term residence (LTR) status. LTR status is in any case a superior status to that of the Blue Card. This is true both when it is a national permanent residence, which allows labour market mobility, or EU LTR status, which has additional provisions for mobility.

203. Most countries do not provide specific facilitations for Blue Card holders in their eligibility for permanent residence. Germany does allow Blue Card holders to apply sooner. Blue Card holders are eligible to apply for permanent residence after 33 months, or 21 months if they have certified German 
language skills at the B-1 level of the Common European Framework (CEF). Other permit categories require 60 months residence. Due to the longer-term nature of the permit, recipients in Finland can access permanent residence sooner than those on the national specialist permit, as temporary stay periods do not count for eligibility. Austria allows Blue Card holders to switch to the more favourable RWR-Plus scheme after 21 months employment in a 24-month period; this allows unrestricted settlement and employment, but cancels any eventual benefit in terms of mobility.

204. The conditions of EU Long Term Residence Permit for former Blue Card holders are more favourable than those for other permit-holders, in terms of the periods of absence allowed (although conditions may be imposed). This permit, marked "Former Holder of EU Blue Card", confers more favourable conditions compared with those usually offered to Blue Card holders: 12 consecutive months absence, and 18 total. These compare with those allowed during stay. Italy, for example, grants 6 consecutive and 10 total for other work permit categories. Belgium does not allow such absences for its national B permit holders, only for Blue Card holders.

\section{Longer duration of permit validity}

205. Art 7(2) of the Directive imposes permit duration. In most countries, Blue Card validity is similar to that of other work permits: contract duration if less than two years, and up to two years for the first permit in the case of longer contracts. In some countries, however, first work permits are issued only for one year (table 3), so that the Blue Card actually represents more favourable conditions. In Belgium, the duration of the Blue Card is longer than the national B permit: following the first renewal, Blue Cards are issued for two and then three years, while B permits must be renewed annually. Bulgaria issues all permits (national and Blue Card) for one year periods. Lithuania offers a longer permit duration, up to three years, compared with two years for other work permits. Austria issues Blue Cards for up to two years, compared with one year for the RWR permit.

206. In the Netherlands, national scheme permits are issued for up to five years, compared with four years for the Blue Card.

Table 4. Duration of first permits, maximum

\begin{tabular}{|c|c|c|c|}
\hline Country & EU Blue Card & $\begin{array}{l}\text { National Scheme for highly } \\
\text { qualified }\end{array}$ & General National Scheme \\
\hline Austria & $2 \mathrm{YR}$ & $1 \mathrm{YR}$ & n.a. \\
\hline Belgium & $1 \mathrm{YR}+1$ month & n.a. & $1 \mathrm{YR}$ \\
\hline Bulgaria & $1 \mathrm{YR}$ & n.a. & $1 \mathrm{YR}$ \\
\hline Czech Republic & $2 \mathrm{YR}$ & $2-3 \mathrm{YR}$ & n.a. \\
\hline Estonia & 2 YR (+3 months) & n.a. & $2 \mathrm{YR}$ \\
\hline Finland & $2 \mathrm{YR}$ & n.a. & $1 \mathrm{YR}$ \\
\hline France & $1-3 \mathrm{YR}$ & n.a. & $\min 1 \mathrm{YR}$ \\
\hline Germany & $4 \mathrm{YR}$ & $1-3 \mathrm{YR}$ & n.a. \\
\hline Greece & $2 \mathrm{YR}$ & n.a. & n.a. \\
\hline Hungary & $1-4 \mathrm{YR}$ & n.a. & n.a. \\
\hline Italy & 2 YR (+3 months) & n.a. & $2 \mathrm{YR}$ \\
\hline Latvia & $5 \mathrm{YR}$ & $5 \mathrm{YR}$ & $5 \mathrm{YR}$ \\
\hline Lithuania & $3 \mathrm{YR}$ & n.a. & $2 \mathrm{YR}$ \\
\hline Luxembourg & $2 \mathrm{YR}$ & $3 \mathrm{YR}$ & n.a. \\
\hline Netherlands & $4 \mathrm{YR}$ & $5 \mathrm{YR}$ & 3 YR (1 YR for less skilled) \\
\hline
\end{tabular}


DELSA/ELSA/WD/SEM(2016)6

\begin{tabular}{|l|l|l|l|}
\hline Poland & $2 \mathrm{YR}$ & n.a. & $3 \mathrm{YR}$ \\
\hline Portugal & $1 \mathrm{YR}$ & $1 \mathrm{YR}$ & n.a \\
\hline Romania & $2(+3) \mathrm{YR}$ & n.a. & n.a. \\
\hline Slovakia & $3 \mathrm{YR}$ & n.a. & 2 YR \\
\hline Slovenia & $2 \mathrm{YR}$ & n.a. & $3 \mathrm{YR}$ \\
\hline Spain & $1 \mathrm{YR}$ & $2 \mathrm{YR}$ & 1YR \\
\hline Sweden & $2 \mathrm{YR}$ & n.a. & $2 \mathrm{YR}$ \\
\hline
\end{tabular}

\section{Permission to stay in case of unemployment}

207. The Blue Card Directive allows recipients at least 3 months unemployment or two spells of unemployment without losing their status (Art. 13). However, most EU countries already allow foreign workers with work permits some margin to seek employment if they are laid off or unemployed through no fault. It is possible to change from a Blue Card to another work permit if the new job does not meet Blue Card criteria but does meet other criteria (and vice versa). Countries with longer unemployment provisions (Italy, 12 months; Spain, for the duration of the permit) apply these to the Blue Card as well. Italy allows Blue Card holders to quit voluntarily and seek a new job, as long as they are register as job seekers. In Belgium, both the Blue Card and B permit holders can run out their permit validity before they must leave if they are still unemployed. In France, while Blue Card holders can run down their permits while jobseeking, standard work permits have better conditions, and allow a one-year automatic extension for job seeking, more than the Blue Card allows. The Netherlands allows Blue Card holders and knowledge migrants three months to seek new work if involuntarily unemployed. In Lithuania, only Blue Card holders are granted a job search period.

208. On the other hand, as countries do not allow Blue Card holders access to non-qualifying employment during the job-search period, unemployed Blue Card holders must find a qualifying job if they wish to work at all. ${ }^{23}$ This can be a significant difference from other work permit holders, for whom the salary, duration and job criteria.

209. As the Blue Card allows mobility for job search, unemployed Blue Card holders can look beyond the country of issuance for new qualifying employment opportunities.

\section{Restrictions on employment changes during permit validity and on renewal}

210. Conditions must be met for the EU Blue Card throughout its validity. No country applies a labour market test on renewal, although where there are LMTs, they also apply in the case of change of employer. In Sweden, employer changes are granted, but profession changes require a new application. Spain grants full labour market access after one year on a general work permit, and the same is thus granted to a Blue Card holder, even if s/he changes employment for an occupation which does not qualify for the Blue Card. In this case, however, the worker loses the Blue Card and acquires a standard work permit. Italy, Estonia, Lithuania and Belgium require Blue Card permit holders to meet Blue Card conditions for the first two years of employment, and requires authorisation from the local labour office for any employer changes In Italy, this is in contrast to the unrestricted labour market access granted to workers who enter under the volumes of admission, who may change employer immediately following arrival. Blue Card holders in Italy may change status to quota-exempt highly-qualified workers.

211. The Blue Card cannot be issued for periods of less than one year, and for contracts of less than one year duration. Any contract of less than one year - even if indefinitely renewable - can only be 
covered by a national scheme. Overall the share of limited duration contract employment in the EU is only about 15\% - and some of these limited contracts are for longer than one year - but the incidence is higher for first employment, for youth and for private sector employment. Further, temporary employment accounts for a growing share of new employment. The Blue Card can be obtained later, if and when the employer offers a longer term contract, although there are fewer incentives for obtaining a Blue Card as the period of residence under national schemes grows longer and labour market mobility and family reunification rights are granted.

212. Table A.4 shows the conditions for employer and employment change during the Blue Card period. In general, given the permit restrictions, Blue Card holders face reporting procedures which are more restrictive than other work permit holders, especially in the period between two years and eligibility for permanent residence (five years), when most countries relax employment restrictions.

213. The Blue Card salary requirement imposes a compliance burden, as holders lose their Blue Card if their salary drops below the threshold, or if their employer fails to pay the contractual salary. Compliance follows the general approach in the countries of implementation: if proof of past salary is a condition for renewal of all work permits, the same is applied to Blue Cards; if no proof is required, renewal requires only the valid contract.

\section{More complex requirements to demonstrate qualifications}

214. The EU Blue Card is often less favourable than national schemes due to criteria for demonstrating qualifications. This obstacle is in addition to the one-year minimum job requirement, which does not apply to national schemes. Rather than introduce specific recognition procedures for the Blue Card, most EU countries use existing recognition frameworks, generally built around the NARIC (National Academic Recognition Information Centres) centres (Table A.3).

215. In many EU countries, the recognition procedure for foreign qualifications is straightforward, and doesn't represent a particularly onerous challenge. Belgium is one example. Sworn, legalised and authenticated translations are required only if the degree is not in English or an official language. Regional economic migration offices evaluate the degree, free of charge, within 30 days.

216. Austria applies the same recognition procedure for qualifications under both the Blue Card and the national scheme, requiring either equivalence through an existing database or individual examination. Recognition in regulated professions can be longer and more expensive, but the procedure is necessary regardless of the permit.

217. The initial transposition in Italy required that applicants hold "a degree and related professional qualification" validated by the Ministry of Instruction, University and Research. This required an notarised copy of the degree, translated and legalised, with a consular declaration of value, as well as a notarised translated and legalised copy of the university transcript, with course names, grades and course descriptions. It was only a year later, with a decree aimed at favouring attractiveness of Italy ${ }^{24}$, that consular authorities were given responsibility for validating degrees, and only regulated professions require further verification. The declaration of value from the consular authorities is considered sufficient. This change significantly lowered the barrier to uptake of the Blue Card.

218. For regulated professions, Italy bases this on Directive 2005/36/EC on the recognition of professional qualifications. For professions not covered by Directives, there is a requirement of 2 years practice in the prior 10 years, and bodies in individual Italian regions are responsible for recognition. 
Recognition for regulated professions can be extremely complex, with the competent Ministry convoking a panel of representatives (from professional associations, the Ministry of Foreign Affairs, and local authorities) to decide on recognition. Outside of health professions and architecture, where a degree from a specific country and institution has already been recognised in a prior case, the panel can be skipped. Nonetheless, the procedure for regulated professions is a barrier to recruitment.

219. In the Netherlands, qualifications must be recognised by NUFFIC, the recognition authority. This does not apply to applicants under the Dutch Knowledge Migrant scheme, although it does apply to general work permit applicants. In any case, the procedure lasts two to four weeks, depending on whether the standard or express fee is paid, and while this is not a high hurdle, the procedure must be completed before the Blue Card can be requested, adding time relative to the rapid national procedure.

220. In Bulgaria, unless documents have a Hague Convention apostille, recognition requires certification by both the issuing country authorities (the Ministry of Foreign Affairs) and the Bulgarian authorities. Certified translation is required. The national NARIC centre then evaluates the degree for recognition. For regulated professions, other institutions are involved.

221. In Lithuania, translation and legalisation are challenges for those living abroad, since all requests and forms must be filed in Lithuanian. While unregulated professional qualifications are all treated by a single authority, which takes one month and has a high recognition rate, the obstacles lie in submitting documentation. For regulated professions, the system is more complex. Nonetheless, this obstacle is identical for applicants for the national work permit.

222. In France, recognition of foreign higher education qualification requires a sworn translation, including proof of duration; the competent body, CIEP, usually takes three to four months to complete its evaluation. The same procedure is required for the Blue Card as for other work permits, so this does not represent a greater obstacle. It is noteworthy, however, that the share of graduates of French universities among new work permits is higher (above one-third) than in other OECD countries. This may reflect the relative ease of recognition of national degrees compared with foreign degrees.

223. In Sweden, from the time the application is filed with the Migration Board, the applicant can request recognition through the public agency for recognition (UHR). Documents are considered authenticated with the stamp of the issuing institution, and an authorised Swedish translation is only required if the document is not in English, French, Spanish, German or a Nordic language. The procedure takes four months. For certain regulated professions, the Migration Board requires prior recognition, which are assessed by the competent authorities.

224. Many, but not all, countries accept English language translations, the Hungarian EU Blue card requires official graduation documents to be translated in Hungarian. Likewise, in Slovakia, a foreign skilled worker has to provide the proof of the required high qualified education or professional qualifications for the position issued by the Slovak Republic (Centre for Recognition of Diplomas of the Ministry of Education, Science, Research and Sports) or by another EU Member State translated into Slovak and authenticated when applying under the EU Blue Card.

\section{More elastic interpretation of experience in lieu of qualifications}

225. The possibility of receiving a permit for highly qualified employment without presenting a tertiary educational qualification is one of the options allowed by the EU Blue Card which make it potentially more accessible than education-based national schemes for highly qualified foreign workers. Setting a threshold for experience was subject to debate during the negotiation, with the Commission's 
initial proposal of three years increased to five in response to the position of the Home Affairs Committee of the European Parliament.

226. Not all countries have taken the option of recognising experience in addition to qualifications. In Belgium, for example, legislators considered it too open to discretion, and declined to include this option. The Netherlands does not allow this; in contrast, its national scheme is entirely salary based, obviating the question. Austria did not include this option, as it is covered under the national RWR scheme for workers in skill shortage occupations.

227. In countries where the option is contemplated, procedures vary. In France, it is based on attestations by prior employers. In Sweden, the employer's evaluation is considered sufficient, although the authorities assess whether the qualifications match the employer's claim of qualifications.

228. Lithuania did include the possibility in its legislation, but as national law does not consider any experience as equivalent to higher education, it is impossible to apply in practice.

\section{Have these changes opened up new opportunities to recruit foreign workers?}

229. The Blue Card Directive as transposed so far have had little effect on the possibility of entry, as candidates meeting the Blue Card requirements already qualified for national schemes. ${ }^{25}$

230. The creation of the Blue Card did not translate into uptake of the permit in most countries. The principal countries of issuance in absolute terms are Germany, France, Spain and Luxembourg. Relative to total labour migration permits issued nationally, Germany and Luxembourg have the highest share of EU Blue Cards. The Blue Card in these countries replaced existing programmes which targeted individuals with similar characteristics and contracts, so the shift is not surprising.

231. A number of countries have already reviewed the impact of the Blue Card in terms of its ability to recruit talented workers. Spain (Government of Spain, 2015) found that its transposition, which kept the more restrictive standards allowed by the directive, "has not been as effective in attracting talent as expected" since it required higher qualifications, set an "excessively high wage limit" which "posed obstacles to hiring, particularly in the case of young graduates", imposed a LMT which was broadly applied, did not contain provisions for a "corporate group concept". In addition, the shortage list was considered to be too restrictive (ISCO 1-2 only) and status changes too difficult.

\section{Have these changes increased EU attractiveness?}

232. There are several mechanisms through which policy changes related to transposition could increase the attractiveness of a single destination country and the broader EU area, even if they do not create new channels for entry.

233. The first is when they ease conditions or criteria for entry. This has not been the case of the Blue Card, which has set qualification and salary requirements at least as high as prior permits.

234. The second is when they increase the transparency, speed or cost of the procedure. One of the main limits of the Blue Card is the need to demonstrate qualifications. The Blue Card, as noted, has not been an occasion for transforming the recognition procedure for higher education qualifications obtained in third countries. Nonetheless, the statutory recognition requirements will place existing frameworks under 
pressure. There is scope for economies of scale at the European level, as already evident in the Austrian use of the German Anabin degree database. The multiplication of higher education institutions in third countries - India and China have seen enormous expansion in their higher education sector - means that recognition will continue to require effort.

235. In terms of overall processing time, most countries covered by the directive already had processing times within the statutory limit prior to transposition. Costs, too, have not been lowered, and have been kept at the same level of pre-existing permits.

236. The third is when they simplify the procedure, either through eliminating steps or providing more information. Labour market test exemptions indeed simplify the procedure in a number of countries. The increasing amount of official information on the Blue Card reduces opportunity costs for candidates and employers.

237. The fourth regards the extra benefits. The Blue Card does allow accompanying family in a number of EU countries which did not previously allow this, although the countries issuing the most Blue Cards (Germany and Luxembourg) have similar policies in place under their national schemes. The mobility benefit is yet to be demonstrated, given the recent transposition of the Directive; similarly, the longer absences under the LTR are still on the horizon.

238. Finally, the question of attractiveness should not be limited to the choice of third-national candidates, but needs to consider employers. In many countries, employers are the actors who decide on the type of permit for which they intend to sponsor a recruit. The possibility of offering a Blue Card, rather than a standard permit, can improve the package offered candidates. More important for employers, however, is the ease of application. LMT exemptions, statutory processing times and automatic approvals make a greater difference than the ancillary benefits provided to applicants.

\section{Have these changes levelled the playing field between third country nationals with work rights and EU citizens?}

239. "Levelling the playing field within the EU" is an objective of labour migration policy instruments. It is specifically cited in the preamble to the Single Permit Directive, but also in documents presenting the Blue Card. ${ }^{26}$ The level playing field, as described in the instruments, refers to the gap between the rights of legally resident third-country nationals and EU citizens, but principally to the differences between EU countries in treatment of employees and employers ${ }^{27}$. In the "absence of a horizontal approach", then, the Directive aims to increase harmonisation of the conditions for admission of highly qualified workers, so that employers in all EU countries face similar requirements in recruitment of highly qualified workers, and can offer permits with similar benefits.

240. The elements listed in this paper show how the Blue Card has been implemented with substantial procedural differences from one country to another, creating a patchwork of national requirements. The salary threshold is one of the main differences, but not the only one: the labour market test, recognition procedures and fees are variable. The facility of job changes both in the first two years and during later renewals varies among countries, with reporting requirements. The possibility to switch into general

$26[\ldots]$ specifying the policy fields where equal treatment with own nationals is provided for third-country workers legally admitted in a Member States but not yet long term residents. Such provisions are intended to establish a level playing field within the EU [...].

27 The sanctions directive is more explicit about levelling the playing field among employers in different countries. 
schemes also varies. Taken together, this means that the Blue Card in one EU country is not the equivalent of a Blue Card in another country.

\section{What are the possible next steps?}

241. Based on the above discussion, there are a number of policy options to improve the Blue Card.

- New opportunities to recruit from abroad

242. The Blue Card has not allowed admission of highly qualified workers who were previously ineligible under the patchwork of national schemes. It can, however, increase the pool of potential candidates applying for jobs in EU countries. One way to achieve this is to arrange a pre-approval mechanism for Blue Card candidates in origin countries, so that individuals could present themselves to employers as "Blue Card approved", by certifying their qualifications and indicating their occupation(s). This would require co-operation in the recognition process, through greater sharing of the knowledge bases such as those developed by NARICs and expansion of their current collaboration. Regulated professions would however remain a hurdle, although degree certification would already help. Similarly, this would not help for those countries which accept experience as a substitute for tertiary qualifications.

243. A further possibility is to introduce a job-search visa for potential Blue Card holders. This would be subject to a limit and potentially to a points-based ranking assessment such as the one used in the United Kingdom for work permits. As noted, most job search permit recipients do not find highly qualified jobs, and this expectation would have to be built into a pilot. Once more is known about the characteristics which determine success in obtaining a Blue Card, selection criteria could be refined.

244. Finally, the salary criterion could be rethought, to reflect the actual distribution of salaries of highly qualified workers, considering the median salaries of tertiary-educated or skilled occupation employees. While it is clear from the discussion that recognition requirements favour highly qualified workers who have graduated in EU universities, the salary threshold, however, is difficult to reach for new graduates. For new third-country international students graduating within the EU, a lower threshold could be applied based on starting salaries in these occupations. It is difficult to identify an appropriate benchmark, since the wage distribution varies across EU countries. Benchmarking the threshold to the actual salary distribution of tertiary-educated workers would reduce this variation. However, this would require using survey data, which is less certain than administrative data and more difficult to use as an automatic policy lever.

\section{- Increasing EU attractiveness}

245. Many of the Blue Cards issued so far - most, in the main countries of issuance - are issued to individuals already legally present. Yet the Directive does not address the question of status change from study or work permits. This could be more explicitly addressed.

246. Opportunities for post-graduation work permits in EU countries range widely, and there is no single procedure. The Blue Card does not appear to the most likely first permit after graduation. The statutory contract duration, too, may represent a barrier for first employment, as initial post-graduate employment is often temporary and short-term. If the Blue Card is to be used to encourage third-country international graduates to stay in the EU, provisions need to be made to reflect salaries of new graduates, as noted above, but also the longer transition period to long-duration contract employment. This could be a bridging period for graduates, allowing shorter-duration contracts during the first year after graduation, as long as the other criteria are met. Those who fail to obtain a longer contract after the period but who have 
found employment can, under the current framework, acquire permits under national schemes (although this may be subject to a labour market test or employer sponsorship regimes).

- $\quad$ Levelling the playing field

247. In terms of levelling the playing field among EU countries, the relative difficulty of obtaining a Blue Card is still variable. Adjusting salary thresholds to reflect real distribution of salaries for highlyqualified workers would go a long way towards levelling the playing field among EU countries in their application of the Blue Card, as would greater harmonization of the recognition process. Even if it were possible to find a reliable survey source on income distribution, and use standard deviations as a reference value to set a universal level of restrictiveness, other variations due to the age and occupational structure of the population would ensure that differences remain.

248. As noted, the reference value of the directive has been interpreted using different indicators in different EU countries. Even if the full-time equivalent annual gross salary is used, the restrictiveness effect varies. No single threshold yields identical results across countries. Nonetheless, using a range of between 1.2 and 2 times the full-time equivalent would prevent some countries from using extremely permissive or restrictive values (table 4). This would affect only the Mediterranean island countries and Italy. On the other hand, in most countries the current Blue Card threshold falls between 1.2 and 1.8, with the exception of Romania and Lithuania.

Table 5. Simulation of the effect of different salary thresholds on the restrictiveness of the Blue Card in different countries

Share of population earning above the threshold, according to different thresholds, based on EU-SILC and GSOEP, 2013, only those in "high educated" category, equivalent to post-secondary non-vocational (ISCED 1997 5-6)

\begin{tabular}{|c|c|c|c|c|c|c|c|c|}
\hline & $\begin{array}{l}\text { Actual BC threshold } \\
2014\end{array}$ & $\begin{array}{l}1 \quad x \\
\text { mean }\end{array}$ & $\begin{array}{l}1.1 x \\
\text { mean }\end{array}$ & $\begin{array}{l}1.2 x \\
\text { mean }\end{array}$ & $\begin{array}{l}1.4 x \\
\text { mean }\end{array}$ & $\begin{array}{l}1.5 x \\
\text { mean }\end{array}$ & $\begin{array}{l}1.7 x \\
\text { mean }\end{array}$ & $\begin{array}{l}2.0 \quad x \\
\text { mean }\end{array}$ \\
\hline AT & 48.5 & 66.6 & 58.5 & 52.6 & 38.5 & 31.7 & 23.4 & 15.7 \\
\hline $\mathrm{BE}$ & 32.8 & 52.9 & 43.2 & 33.7 & 22.0 & 18.5 & 12.6 & 7.8 \\
\hline$B G$ & 44.0 & 61.7 & 50.4 & 43.6 & 30.2 & 25.4 & 17.9 & 12.8 \\
\hline CY & 56.7 & 53.9 & 49.2 & 44.5 & 34.8 & 31.4 & 24.6 & 15.6 \\
\hline CZ & 28.5 & 70.7 & 61.8 & 53.0 & 36.7 & 32.3 & 23.1 & 16.0 \\
\hline $\mathrm{DE}$ & 52.6 & 65.3 & 56.7 & 47.8 & 35.2 & 30.5 & 20.8 & 11.5 \\
\hline $\mathrm{EE}$ & 19.5 & 50.2 & 43.3 & 38.6 & 29.1 & 26.5 & 17.5 & 12.9 \\
\hline EL & 16.5 & 54.8 & 44.3 & 35.7 & 23.6 & 17.8 & 13.2 & 8.4 \\
\hline ES & 37.2 & 60.5 & 54.7 & 48.0 & 37.2 & 31.5 & 21.0 & 13.7 \\
\hline $\mathrm{FI}$ & 27.9 & 55.5 & 46.1 & 39.3 & 27.8 & 23.7 & 16.0 & 9.3 \\
\hline FR & 16.9 & 57.6 & 48.3 & 39.7 & 27.4 & 22.9 & 16.7 & 10.9 \\
\hline $\mathrm{HR}$ & 20.3 & 76.8 & 71.7 & 65.1 & 49.0 & 39.7 & 24.7 & 17.5 \\
\hline $\mathrm{HU}$ & 24.8 & 71.3 & 63.3 & 56.0 & 42.9 & 39.0 & 29.4 & 17.9 \\
\hline IT & 71.9 & 58.8 & 49.5 & 41.0 & 28.2 & 24.7 & 19.8 & 13.5 \\
\hline LT & 3.9 & 58.8 & 51.7 & 45.4 & 33.9 & 29.4 & 21.0 & 15.2 \\
\hline LU & 58.9 & 72.0 & 65.5 & 59.3 & 45.8 & 38.7 & 24.8 & 16.1 \\
\hline LV & 28.6 & 59.4 & 53.1 & 46.5 & 35.3 & 30.9 & 23.6 & 17.4 \\
\hline MT & 84.2 & 68.2 & 57.7 & 46.3 & 30.8 & 26.5 & 20.3 & 11.8 \\
\hline NL & 47.7 & 61.1 & 53.0 & 44.0 & 27.9 & 22.3 & 14.4 & 9.0 \\
\hline PL & 25.1 & 60.3 & 52.2 & 45.5 & 34.6 & 30.6 & 23.0 & 15.0 \\
\hline PT & 74.4 & 77.1 & 71.9 & 65.9 & 52.2 & 46.6 & 37.8 & 26.7 \\
\hline RO & 0.2 & 71.5 & 66.0 & 59.1 & 41.5 & 35.3 & 26.0 & 12.7 \\
\hline SE & 22.7 & 48.5 & 38.7 & 31.6 & 20.7 & 17.2 & 11.7 & 7.1 \\
\hline
\end{tabular}




\begin{tabular}{lrrrrrrrr} 
SI & 42.6 & 68.5 & 62.1 & 55.8 & 41.7 & 34.4 & 25.3 & 16.9 \\
SK & 12.7 & 66.6 & 48.6 & 42.2 & 25.1 & 22.3 & 12.8 & 8.7 \\
\hline BC average (total) & & $\mathbf{6 1 . 2}$ & $\mathbf{5 2 . 9}$ & $\mathbf{4 5 . 7}$ & $\mathbf{3 3 . 0}$ & $\mathbf{2 8 . 1}$ & $\mathbf{1 8 . 8}$ & $\mathbf{1 3 . 1}$ \\
\hline
\end{tabular}

249. Additional information for employers on the Blue Card eligibility and process, as well as on the facilitations for hiring Blue Card holders currently employed in another EU country, would extend uptake of this measure.

\section{- Favouring mobility}

250. Holding a Blue Card should make it easier for highly qualified individuals to quickly take up employment in a second EU country while conserving some of the privileges they enjoy under the scheme. The obstacles to mobility are the same that apply to initial issuance: recognition of qualifications, meeting a salary threshold and holding a contract for more than 12 months employment. Further, prospective employers in the second country are not aware of the mobility advantages of Blue Card holders. Further development of matching tools - including the EURES Mobility Platform - should allow employers to search among candidates who already hold permits with mobility provisions, since they will be able to take up employment quickly. 


\section{BIBLIOGRAPHY}

Caritas (2002), “La sponsorizzazione, una possibilità soppressa", pp. 119-125, in Caritas e Migrantes Immigrazione Dossier Statistico 2002, Nuova Anterem, Rome.

Chaloff, J. (2014), "Evidence-based regulation of labour migration in OECD countries: setting quotas, selection criteria, and shortage lists", in Migration Letters, 2014, vol. 11, issue 1, pp. 11-22. http://www.metapress.com/content/u193r57512k023u0/fulltext.pdf

European Commission (2007), Commission of the European Communities, Accompanying document to the Proposal for a Council Directive on the conditions of entry and residence of third country nationals for the purpose of highly qualified employment: Impact Assessment, SEC(2007) 1403, 23.10.2007, Brussels

EMN Synthesis report (2012), Immigration of International Students to the EU, European Commission, see:

http://emn.ie/files/p_201303261159332013_EMN_Synthesis_Immigration_of_International _Students_March2013_FINAL.pdf

Finnish Ministry of the Interior (2013), Government Resolution on the Future of Migration 2020 Strategy, 13 June 2013, https://www.intermin.fi/download/52271_Maahanmuuton_tulevaisuus_2020_ENG_LOWres_v2.pdf

Government of Slovak Republic (2011), Migration policy of the Slovak Republic: Perspective until the year 2020, Government of the Slovak Republic Resolution No. 574, 31 August 2011

Government of Spain (2015), Report on the Implementation of the International Mobility Section of the Entrepreneurial Support and Internationalisation Act of 27 September 2013, http://extranjeros.empleo.gob.es/es/UnidadGrandesEmpresas/ley14_2013/documentacion/R eport_on_the_Implementation_of_the_International_Mobility_Section.pdf

ICMPD (2011), 'Assessment of the Implementation and Impact of the Scientific Visa Package' see http://research.icmpd.org/research-home/projects/migration-governance/scientific-visaproject/

Migration Advisory Committee (2015), Review of Tier 2: Analysis of Salary Thresholds, Migration Advisory Committee, London, July 2015 
OECD (2011), Recruiting Immigrant Workers: Sweden 2011, OECD Publishing, Paris. DOI: http://dx.doi.org/10.1787/9789264167216-en

OECD (2012), Better Skills, Better Jobs, Better Lives: A Strategic Approach to Skills Policies, OECD Publishing, Paris. DOI: http://dx.doi.org/10.1787/9789264177338-en

OECD (2013), Recruiting Immigrant Workers: Germany 2013, OECD Publishing, Paris. DOI: http://dx.doi.org/10.1787/9789264189034-en

OECD (2014a), "Managing labour migration: Smart policies to support economic growth", in OECD, International Migration Outlook 2014, OECD Publishing, Paris.

DOI: http://dx.doi.org/10.1787/migr_outlook-2014-6-en

OECD (2014b), Recruiting Immigrant Workers: Norway 2014, OECD Publishing, Paris. DOI: http://dx.doi.org/10.1787/9789264226135-en

OECD (2014c), Recruiting Immigrant Workers: Austria 2014, OECD Publishing, Paris. DOI: http://dx.doi.org/10.1787/9789264226050-en

OECD (2014d), Jobs for Immigrants (Vol. 4): Labour Market Integration in Italy, OECD Publishing, Paris.

DOI: http://dx.doi.org/10.1787/9789264214712-en

OECD (2016, forthcoming), Recruiting Immigrant Workers: Netherlands 2016, OECD Publishing, Paris.

Roos, Christof, (2013), 'The EU and Immigration Policies: Cracks in the walls of Fortress Europe?', Transformations of the State series, University of Bremen

Wind, M., S. Adamo (2015) Is Green better than Blue? The Danish JHA opt-out and the Unilateral attempt to attract highly skilled labour. European Journal of Migration and Law, Vol. 17, 2015, pp. 329-361. 
ANNEX TABLES AND FIGURES

Table A.1. Labour market test processes in EU/EEA countries

\begin{tabular}{|c|c|c|c|c|}
\hline Country & Agency responsible & LMT Process & $\begin{array}{l}\text { Duration } \\
\text { advertising } \\
\text { requirements }\end{array}$ & Exemptions \\
\hline $\begin{array}{l}\text { Austria } \\
\text { Seasonal } \\
\text { Programme } \\
\text { RWR card }\end{array}$ & $\begin{array}{l}\text { PES - Service für } \\
\text { Unternehmen (Service for } \\
\text { Companies). }\end{array}$ & $\begin{array}{l}\text { The labour market test (Arbeitsmarktprïfung) must } \\
\text { show that there is no Austrian or eligible non-Austrian } \\
\text { worker registered with the Austrian Migration Services } \\
\text { available for the job. }\end{array}$ & $\begin{array}{l}\text { No fixed period, but in } \\
\text { practice } 2-3 \text { weeks }\end{array}$ & \\
\hline $\begin{array}{l}\text { Belgium } \\
\text { Less skilled jobs }\end{array}$ & LMT only for certain jobs & $\begin{array}{l}\text { For less-skilled jobs, one needs to be from a country } \\
\text { with which a bilateral agreement has been signed and } \\
\text { the LMT implemented differently in the three regions. } \\
\text { 1) Flanders PES. Potential local candidates come to the } \\
\text { case worker, who refers them to the employer. After } 2 \\
\text { weeks, the employer has to report on the job } \\
\text { applications. Then the case worker drafts an advice } \\
\text { (positive or negative), which is then confirmed by her } \\
\text { superior and sent back to the economic migration } \\
\text { office. 4-6 weeks total. }\end{array}$ & $\begin{array}{l}\text { Flanders: two weeks. Brussels } \\
\text { and Wallonia: based on job } \\
\text { seekers. }\end{array}$ & $\begin{array}{l}\text { The regional } \\
\text { bottleneck lists exist, } \\
\text { only for countries } \\
\text { covered } \\
\text { transitional } \\
\text { arrangements } \\
\text { (currently, Croatians) } \\
\text { and for long-term } \\
\text { residents who } \\
\text { obtained that status in } \\
\text { another EU member }\end{array}$ \\
\hline
\end{tabular}




\begin{tabular}{|c|c|c|c|c|}
\hline 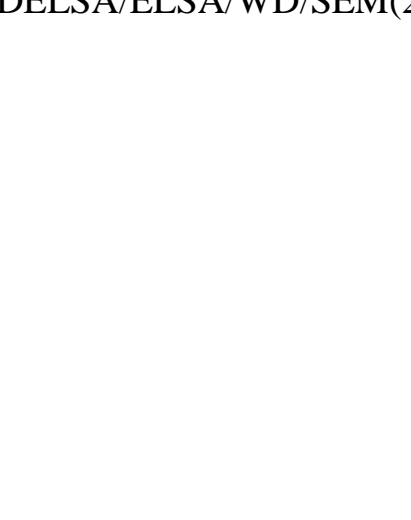 & & $\begin{array}{l}\text { 2) Brussels uses a coefficient: labour reserve/vacancies, } \\
\text { for occupations with more than } 100 \text { vacancies. The PES } \\
\text { divides the number of registered job seekers for the } \\
\text { occupation by the number of vacancies. If the } \\
\text { coefficient is } 12 \text { or more, then the LMT gets a negative } \\
\text { response. This takes about a week. } \\
\text { 3) Wallonia, there is a check if there are candidates for } \\
\text { the particular low skilled profession in Wallonia (entire } \\
\text { region). if there are: the labour market test results in a } \\
\text { negative answer. Duration: } 11 \text { days. }\end{array}$ & & $\begin{array}{l}\text { state on the basis of } \\
\text { the EU Directive } \\
\text { 2003/109/EC and who } \\
\text { wish to work in } \\
\text { Belgium. }\end{array}$ \\
\hline Bulgaria & Employment Agency & $\begin{array}{l}\text { Vacancy listing required. Executive Director of the } \\
\text { Employment Agency gives a written decision. Further, } \\
\text { no more than } 10 \% \text { of payroll in previous } 12 \text { months can } \\
\text { be non EU/EEA/EFTA nationals or LTRs, family or } \\
\text { humanitarian status holders. The Employment Agency } \\
\text { also checks the conditions of work and salary, which } \\
\text { must be at least as favourable as those of Bulgarian } \\
\text { citizens in the labour category. }\end{array}$ & Not specified & $\begin{array}{l}\text { ISCO } 1-2 \text { shortage } \\
\text { occupations }\end{array}$ \\
\hline $\begin{array}{l}\text { Czech Republic } \\
\text { Green Card - Type C } \\
\text { Green Card - A and B, EU } \\
\text { Blue Card }\end{array}$ & $\begin{array}{l}\text { Ministry of Labour and } \\
\text { Social Affairs, Ministry of } \\
\text { Industry and Trade }\end{array}$ & $\begin{array}{l}\text { The Ministry of Labour and Social Affairs maintains a } \\
\text { register of vacancies lodged by employers. The } \\
\text { Ministry of Industry and Trade declares it open to } \\
\text { migrants when it is not filled by a citizen of the Czech } \\
\text { Republic or the EU within } 30 \text { days. }\end{array}$ & 30 days & \\
\hline $\begin{array}{l}\text { Estonia } \\
\text { Residence permit, EU Blue } \\
\text { Card }\end{array}$ & $\begin{array}{l}\text { Estonian Unemployment } \\
\text { Insurance Fund }\end{array}$ & $\begin{array}{l}\text { At the request of an employer the Estonian } \\
\text { Unemployment Insurance Fund may grant to the } \\
\text { employer a permission to fill the position by employing } \\
\text { an alien if the employer has failed to find a suitable } \\
\text { candidate and, considering the situation in the labour } \\
\text { market }\end{array}$ & $\begin{array}{l}\text { None; a 3-week requirement } \\
\text { was eliminated in } 2013\end{array}$ & $\begin{array}{l}\text { Graduates from an } \\
\text { Estonian higher } \\
\text { educational } \\
\text { institution; specialists } \\
\text { with double the } \\
\text { national average } \\
\text { salary }\end{array}$ \\
\hline
\end{tabular}


DELSA/ELSA/WD/SEM(2016)6

\begin{tabular}{|c|c|c|c|c|}
\hline $\begin{array}{l}\text { Finland } \\
\text { Residence permit }\end{array}$ & Labour Office & $\begin{array}{l}\text { Labour Office collects information on working contract } \\
\text { details, (wages, collective agreement, working hours, } \\
\text { etc.). The labour office makes a partial decision where } \\
\text { it determines the professional field or fields, salary } \\
\text { level, relevant collective agreement, type of the permit } \\
\text { (temporary or permanent) and the validity of the permit } \\
\text { (normally first permit is for one year). }\end{array}$ & 14-28 days & \\
\hline $\begin{array}{l}\text { France } \\
\\
\text { Seasonal } \\
\begin{array}{l}\text { Programme } \\
\text { Temporary Work Permit } \\
\text { for Salarié } \\
\text { Worker) }\end{array} \text { (Salaried }\end{array}$ & PES & $\begin{array}{l}\text { Publication with the public employment service or } \\
\text { through private channels. } \\
\text { Employer must submit application to the Department of } \\
\text { Labour, Employment and Vocational Training Service } \\
\text { for a discretionary review of professional } \\
\text { qualifications, contract wage and conditions, } \\
\text { technological and commercial added value, and to } \\
\text { determine whether the job could be performed by a } \\
\text { resident. }\end{array}$ & & $\begin{array}{l}\text { Shortage Occupation } \\
\text { List, skills and talent } \\
\text { criteria or EU Blue } \\
\text { Card. }\end{array}$ \\
\hline $\begin{array}{l}\text { Germany } \\
\text { Residence permit for } \\
\text { temporary employment }\end{array}$ & Local PES/ZAV & $\begin{array}{l}\text { PES checks conditions of offer and then decides to list } \\
\text { a vacancy. }\end{array}$ & 7-14 days & Shortage occupations. \\
\hline $\begin{array}{l}\text { Greece } \\
\text { Residence permit for } \\
\text { purpose of work }\end{array}$ & $\begin{array}{l}\text { Service for Foreigners \& } \\
\text { Migration of the } \\
\text { Decentralized } \\
\text { Administration approves } \\
\text { employer application } \\
\text { "inviting" specific TCN } \\
\text { workers }\end{array}$ & $\begin{array}{l}\text { There is no individual LMT. Employers have to } \\
\text { "invite" an employee from the pool of occupations } \\
\text { identified through a centrally managed Volumes of } \\
\text { Admission process and subject to satisfying the criteria } \\
\text { set for that occupation. }\end{array}$ & n.a. & $\begin{array}{l}\text { The Volumes of } \\
\text { Admission system is } \\
\text { similar to an } \\
\text { anticipated shortage } \\
\text { list valid for } 2 \text { years. }\end{array}$ \\
\hline
\end{tabular}


DELSA/ELSA/WD/SEM(2016)6

\begin{tabular}{|c|c|c|c|c|}
\hline $\begin{array}{l}\text { Hungary } \\
\text { Work permit/seasonal work } \\
\text { permit } \\
\text { EU Blue card }\end{array}$ & PES & $\begin{array}{l}\text { Employer must advertise the job through the } \\
\text { employment centre of the district where the business is } \\
\text { located, by filling in and submitting a data sheet and a } \\
\text { "demand for labour" reporting sheet. }\end{array}$ & 15 days & \\
\hline $\begin{array}{l}\text { Ireland } \\
\text { Work Permit }\end{array}$ & $\begin{array}{l}\text { Department of Social } \\
\text { Protection } \\
\text { Employment Services }\end{array}$ & $\begin{array}{l}\text { Listing in the FAS/EURES (Job Mobility Portal) } \\
\text { system for } 2 \text { weeks and advertisements in national } \\
\text { press for } 3 \text { days - advertisement in local newspaper is } \\
\text { optional, showing that the positions could not be filled } \\
\text { from within the EEA/EU. }\end{array}$ & $3-14$ days & $\begin{array}{lr}\text { Highly } & \text { Skilled } \\
\text { Occupations } & \text { List, } \\
\text { Ineligibles List. }\end{array}$ \\
\hline $\begin{array}{l}\text { Italy } \\
\text { Seasonal Programme } \\
\text { Work Permit (open and fix } \\
\text { term contracts) }\end{array}$ & PES & $\begin{array}{l}\text { Prior listing with public employment service for } 20 \\
\text { days. Provincial labour office required to check } \\
\text { availability of candidates (resident in Italy). In the } \\
\text { absence of response, approval is automatic. If the PES } \\
\text { proposes local candidates, the application is suspended } \\
\text { until employers confirm their continued intention to } \\
\text { recruit from abroad. }\end{array}$ & 20 days & $\begin{array}{l}\text { Pre-approved } \\
\text { employers with a } \\
\text { protocol with the } \\
\text { Ministry of Interior, } \\
\text { for Blue Card or } \\
\text { highly qualified } \\
\text { workers (executives) }\end{array}$ \\
\hline $\begin{array}{l}\text { Lithuania } \\
\text { General Work Permit }\end{array}$ & PES & $\begin{array}{l}\text { Must list job one month before submitting an } \\
\text { application to the local labour exchange. Employer } \\
\text { wishing to recruit more than five foreign workers must } \\
\text { advertise locally at least three months in advance. }\end{array}$ & 30 days -90 days & $\begin{array}{l}\text { Exemption if salaries } \\
\text { exceeds three times } \\
\text { the monthly average }\end{array}$ \\
\hline $\begin{array}{l}\text { Luxembourg } \\
\text { Travailleur } \\
\text { (Salaried Worker) }\end{array}$ & PES (ADEM) & $\begin{array}{l}\text { Job must be submitted to the public employment } \\
\text { service (ADEM). If no candidates are registered, the } \\
\text { application may be approved after a } 3 \text {-week period. }\end{array}$ & 18 days & $\begin{array}{l}\text { Researchers, posted } \\
\text { workers, athletes. }\end{array}$ \\
\hline
\end{tabular}


DELSA/ELSA/WD/SEM(2016)6

\begin{tabular}{|c|c|c|c|c|}
\hline $\begin{array}{l}\text { Netherlands } \\
\text { Labour Migrant Work } \\
\text { Permit }\end{array}$ & $\begin{array}{l}\text { PES (WERKbedrijf - } \\
U W V)\end{array}$ & $\begin{array}{l}\text { The employer must notify the Dutch employment } \\
\text { agency of vacancy and conduct recruitment to } \\
\text { determine whether there are qualified and available } \\
\text { workers in the EEA labour market. Employers must } \\
\text { advertise the vacant position for at least five weeks } \\
\text { through standard recruitment channels, such as Dutch } \\
\text { newspapers, professional or trade journals, online job } \\
\text { boards, or placement agencies. }\end{array}$ & 5 weeks & $\begin{array}{l}\text { Intra-company } \\
\text { transferees who } \\
\text { receive an annual } \\
\text { salary of at least } \\
\text { EUR } 50000\end{array}$ \\
\hline $\begin{array}{l}\text { Poland } \\
\text { Work Permit }\end{array}$ & PES (Starosta) & $\begin{array}{l}\text { Regional PES authorises an employer once it has } \\
\text { advertised with the public employment services and } \\
\text { local media. PES gives its opinion considering either } \\
\text { the local registry of unemployed and job seekers or by } \\
\text { organizing a special recruitment for the employer } \\
\text { (usually the former). If the employer rejects candidates, } \\
\text { the PES could still give a positive opinion. Employers } \\
\text { may appeal negative decisions directly to the Ministry } \\
\text { of Labour and Social Policy. } \\
\text { Duration maximum } 14 \text { days for decision by Starosta } \\
\text { (local labour office) if local unemployed or job seekers } \\
\text { are available. Otherwise, } 7 \text { days. }\end{array}$ & 14 days & $\begin{array}{l}\text { Work in the list of } \\
\text { occupations which are } \\
\text { in high demand; work } \\
\text { as a domestic worker } \\
\text { or a care-giver from a } \\
\text { country bordering } \\
\text { Poland. }\end{array}$ \\
\hline $\begin{array}{l}\text { Portugal } \\
\text { Residence Visa/Work } \\
\text { Permit/Seasonal Temporary } \\
\text { stay work }\end{array}$ & PES & $\begin{array}{l}\text { Regional employment service issues authorisation once } \\
\text { an employer has advertised vacancy with public } \\
\text { employment services and local media. As a transitional } \\
\text { measure for the implementation of the global quota, the } \\
\text { PES publishes all vacancies not filled after } 30 \text { days by } \\
\text { Portuguese citizens, nationals of European Union } \\
\text { Member States, of the European Economic Area, of a } \\
\text { third-country with which the European Community has } \\
\text { concluded an agreement on free movement of people, } \\
\text { or by third-countries nationals that legally reside in } \\
\text { Portugal. }\end{array}$ & 30 days & $\begin{array}{l}\text { Ineligible occupation } \\
\text { list (not currently } \\
\text { used) }\end{array}$ \\
\hline
\end{tabular}




\begin{tabular}{|c|c|c|c|c|}
\hline $\begin{array}{l}\text { Romania } \\
\text { Work Permit (and trainees) }\end{array}$ & PES & $\begin{array}{l}\text { Proof the employer has endeavoured to fill the vacancy } \\
\text { by a Romanian citizen, EU, EEA, Swiss national or } \\
\text { third-country long term resident in Romania. Requires } \\
\text { recent proof by the local labour agency of the } \\
\text { unavailability of labour force qualified to fill the } \\
\text { vacancies; proof of publication in a general circulation } \\
\text { newspaper in Romania of at least one ad to fill the } \\
\text { vacancy; copy of the report prepared by the employer } \\
\text { on the selection made to fill the vacancy. }\end{array}$ & & \\
\hline Slovak Republic & $\begin{array}{l}\text { Office of Labour, Social } \\
\text { Affairs and the Family }\end{array}$ & $\begin{array}{l}\text { Advertised by local public employment office, website, } \\
\text { information board, EURES Job Mobility Portal. }\end{array}$ & 30 days & $\begin{array}{l}\text { Posted workers, } \\
\text { workers defined by } \\
\text { WTO rules, clerical } \\
\text { workers, etc. }\end{array}$ \\
\hline Slovenia & PES & $\begin{array}{l}\text { Employers must register the job vacancy before } \\
\text { submitting an application for the issuance of a work } \\
\text { permit. The PES has } 8 \text { working days to notify the } \\
\text { employer of appropriate registered unemployed (i.e., } \\
\text { registered in national register). The PES may consider } \\
\text { if the employment of a foreign national adversely } \\
\text { affects the Slovenian labour market. }\end{array}$ & 30 days & $\begin{array}{lr}\text { Provisions } & \text { for } \\
\text { shortage } & \text { occupation } \\
\text { list, } & \text { scientists, } \\
\text { teachers, etc. }\end{array}$ \\
\hline $\begin{array}{l}\text { Spain } \\
\text { Seasonal Work } \\
\text { EU Blue Card }\end{array}$ & PES & $\begin{array}{l}\text { Job must be listed with the public employment services } \\
\text { for } 25 \text { days, and employers must interview candidates } \\
\text { sent by the public employment service, although they } \\
\text { may reject them. }\end{array}$ & 25 days & $\begin{array}{l}\text { Shortage list } \\
\text { occupations governed } \\
\text { by collective } \\
\text { management of } \\
\text { contracts agreements } \\
\text { with the countries of } \\
\text { origin or the } \\
\text { Catalogue of Hard-to } \\
\text { Fill Jobs. }\end{array}$ \\
\hline $\begin{array}{l}\text { Sweden } \\
\text { Work Permit }\end{array}$ & PES (Arbetsformedlingen) & $\begin{array}{l}\text { Vacancies should be advertised for } 10 \text { days with the } \\
\text { public employment services (automatic listing with } \\
\text { EURES Job Mobility Portal). No obligation to hire any } \\
\text { candidates responding to job listing. }\end{array}$ & 10 days & \\
\hline
\end{tabular}


DELSA/ELSA/WD/SEM(2016)6

\begin{tabular}{|c|c|c|c|c|}
\hline $\begin{array}{l}\text { United Kingdom } \\
\text { Sector Based Scheme (SBS) } \\
\text { Tier } 2 \text { Skilled worker }\end{array}$ & PES & $\begin{array}{l}\text { Resident Labour Market Test (RLMT) - employers } \\
\text { must advertise for EEA workers, submit proof of } \\
\text { advertisement within past } 6 \text { months, supply information } \\
\text { on applicants and selection process, and justify not } \\
\text { hiring applicants. Since } 2009 \text { employers are required to } \\
\text { advertise through Jobcentre Plus and at least one other } \\
\text { medium. Employers free to select media outlet but must } \\
\text { follow specific requirements for the medium chosen. }\end{array}$ & $\begin{array}{l}28 \text { days - either consecutively } \\
\text { or in separate periods of no } \\
\text { less than } 7 \text { days. }\end{array}$ & $\begin{array}{l}\text { Intra-company } \\
\text { transfers }\end{array}$ \\
\hline $\begin{array}{l}\text { Norway } \\
\text { Seasonal Work Programme } \\
\text { Skilled Worker } \\
\text { (ARBDTAKFAGORD) }\end{array}$ & PES (NAV) & $\begin{array}{l}\text { LMA (labour market assessment) applies when there is } \\
\text { no set quota, or when the quota (for the agriculture and } \\
\text { forestry industry and for skilled workers) has been } \\
\text { filled. The Labour and Welfare Service (NAV) carry } \\
\text { out the LMT (guidelines issued by the Directorate of } \\
\text { Labour and Welfare). } \\
\text { In practice, does not use the EURES Job Mobility } \\
\text { Portal, but the EURES advisers work within Europe to } \\
\text { contact partners and identify candidates for specific } \\
\text { positions, outside of the LMT. }\end{array}$ & n.a. & $\begin{array}{l}\text { LMA required only } \\
\text { when quota is filled. } \\
\text { So far, only applied } \\
\text { for non- } \\
\text { agricultural/forestry } \\
\text { seasonal workers and } \\
\text { holiday replacements }\end{array}$ \\
\hline $\begin{array}{l}\text { Switzerland } \\
\text { Residence Permit }\end{array}$ & PES & $\begin{array}{l}\text { No time limit specified for listing with Cantonal Public } \\
\text { Employment Service, EURES Job Mobility Portal or } \\
\text { other channels, other than taking steps within a } \\
\text { "reasonable time". Federal Office for Migration must } \\
\text { also approve the request. } \\
\text { EURES Job Mobility Portal appears to be one - but } \\
\text { not only - channel. }\end{array}$ & & $\begin{array}{l}\text { Intra-company } \\
\text { transferees, high-level } \\
\text { executives and } \\
\text { investors, service, au } \\
\text { pairs, sportspeople. }\end{array}$ \\
\hline
\end{tabular}


Table A.2. Overview of main features of labour migration policy

\begin{tabular}{|c|c|c|c|c|c|c|}
\hline & EU (excl. UK) & $\mathbf{U K}$ & AUS & $\mathbf{C A N}$ & NZL & USA \\
\hline $\begin{array}{l}\text { Two-Step } \\
\text { Migration }\end{array}$ & $\begin{array}{l}\text { Almost all initial permits } \\
\text { are temporary, } \\
\text { renewable, with } \\
\text { eligibility for permanent } \\
\text { residence as early as } 2 \\
\text { years and as late as } 5 \\
\text { years }\end{array}$ & $\begin{array}{l}\text { Almost all initial permits } \\
\text { are temporary, } \\
\text { renewable, with } \\
\text { eligibility for permanent } \\
\text { residence at } 5 \text { years }\end{array}$ & $\begin{array}{l}\text { Separate temporary and } \\
\text { permanent tracks. In } \\
\text { principle, temporary } \\
\text { migration feeds most of } \\
\text { permanent migration }\end{array}$ & $\begin{array}{l}\text { Separate temporary and } \\
\text { permanent tracks. In } \\
\text { principle, temporary } \\
\text { migration feeds most of } \\
\text { permanent migration }\end{array}$ & $\begin{array}{l}\text { Separate temporary and } \\
\text { permanent tracks. In } \\
\text { principle, temporary } \\
\text { migration feeds most of } \\
\text { permanent migration }\end{array}$ & $\begin{array}{l}\text { Separate temporary and } \\
\text { permanent tracks. In } \\
\text { principle, temporary } \\
\text { migration feeds most of } \\
\text { permanent migration }\end{array}$ \\
\hline $\begin{array}{l}\text { Supply- } \\
\text { driven }\end{array}$ & $\begin{array}{l}\text { Very few cases, almost } \\
\text { all temporary }\end{array}$ & $\begin{array}{l}\text { Very few cases, } \\
\text { exceptional individuals }\end{array}$ & $\begin{array}{l}\text { Main programme, even if } \\
\text { in practice most } \\
\text { successful applicants } \\
\text { have job offers (priority) }\end{array}$ & $\begin{array}{l}\text { Main programme, even if } \\
\text { in practice most } \\
\text { successful applicants } \\
\text { have job offers (priority) }\end{array}$ & $\begin{array}{l}\text { Main programme, even if } \\
\text { in practice most } \\
\text { successful applicants } \\
\text { have job offers (priority) }\end{array}$ & $\begin{array}{l}\text { Mostly based on job- } \\
\text { offer, except for the most } \\
\text { exceptional (who usually } \\
\text { have a job offer anyway) }\end{array}$ \\
\hline $\begin{array}{l}\text { Skill } \\
\text { thresholds } \\
\text { / Selection } \\
\text { criteria }\end{array}$ & $\begin{array}{l}\text { Variable. } \\
\text { Either } \text { Temporary: } \\
\text { threshold or LMT or } \\
\text { both. }\end{array}$ & $\begin{array}{l}\text { Tertiary-level or } \\
\text { professional } \\
\text { requirements, salary used }\end{array}$ & $\begin{array}{ll}\text { Permanent: } & \text { PBS, } \\
\text { weighted towards local } \\
\text { experience/study; } \\
\text { language. } \\
\text { elements. } \\
\text { Temporary: occupation- } \\
\text { based, LMT }\end{array}$ & $\begin{array}{l}\text { Permanent: } \\
\text { weighted towards local } \\
\text { experience/study; } \\
\text { language. } \\
\text { elements. } \\
\text { Temporary: occupation- } \\
\text { based, LMT }\end{array}$ & $\begin{array}{l}\text { Permanent: } \\
\text { weighted towards local } \\
\text { experience/study. Other } \\
\text { elements. } \\
\text { Temporary: occupation- } \\
\text { based, LMT }\end{array}$ & $\begin{array}{l}\text { Permanent: Multi-tiered } \\
\text { system with priority } \\
\text { given to the most } \\
\text { qualified, visa spill- } \\
\text { overs, small permanent } \\
\text { channel for low-skilled } \\
\text { Temporary: occupation- } \\
\text { based, light LMT }\end{array}$ \\
\hline $\begin{array}{l}\text { Numerical } \\
\text { limits }\end{array}$ & $\begin{array}{l}\text { Variable, most countries } \\
\text { do not impose limits on } \\
\text { skilled migration. }\end{array}$ & $\begin{array}{l}\text { Primary applicant limit } \\
\text { for Tier } 2 \text { equal to } 0.03 \% \\
\text { of total population } \\
(2012) \text {, for Tier } 1 \text { equal } \\
\text { to } 0.003 \%(2012)\end{array}$ & $\begin{array}{l}\text { Primary applicant target, } \\
\text { equal to } 0.26 \% \text { of total } \\
\text { population }(2012)\end{array}$ & $\begin{array}{l}\text { Primary applicant target, } \\
\text { equal to } 0.19 \% \text { of total } \\
\text { population }(2012)\end{array}$ & $\begin{array}{l}\text { Primary applicant target, } \\
\text { equal to } 0.22 \% \text { of total } \\
\text { population }(2012)\end{array}$ & $\begin{array}{l}\text { Limits set for temporary } \\
(0.03 \% \text { of population) } \\
\text { and permanent } \\
\text { employment }(0.02 \%)\end{array}$ \\
\hline $\begin{array}{l}\text { Seasonal } \\
\text { workers }\end{array}$ & $\begin{array}{l}\begin{array}{l}\text { Variable, } \\
\text { some }\end{array} \\
\text { programmes, some but } \\
\text { not all are capped, } \\
\text { conditioned by the } \\
\text { Seasonal } \\
\text { Directive }\end{array}$ & Expired & $\begin{array}{l}\text { Bilateral programmes, } \\
\text { capped }\end{array}$ & Bilateral programmes & $\begin{array}{l}\text { General and Bilateral } \\
\text { programmes, capped }\end{array}$ & programmes, \\
\hline
\end{tabular}




\begin{tabular}{|c|c|c|c|c|c|c|}
\hline & transposition) & & & & & \\
\hline Students & $\begin{array}{l}\text { Variable, conditioned by } \\
\text { the EU Student Directive }\end{array}$ & $\begin{array}{l}\text { Part of labour migration } \\
\text { channel, no favourable } \\
\text { conditions }\end{array}$ & $\begin{array}{l}\text { Large part of labour } \\
\text { migration channel. } \\
\text { Favourable status change } \\
\text { conditions (priority, job } \\
\text { search extension) }\end{array}$ & $\begin{array}{l}\text { Large part of labour } \\
\text { migration channel. } \\
\text { Favourable status change } \\
\text { conditions (priority, job } \\
\text { search extension) }\end{array}$ & $\begin{array}{l}\text { Large part of labour } \\
\text { migration channel. } \\
\text { Favourable status change } \\
\text { conditions (priority, job } \\
\text { search extension) }\end{array}$ & $\begin{array}{l}\text { Part of labour migration } \\
\text { channel. Favourable } \\
\text { status change conditions } \\
\text { (master's degree set- } \\
\text { asides in H-1B, OPT } \\
\begin{array}{l}\text { extension to study } \\
\text { permits) }\end{array}\end{array}$ \\
\hline $\begin{array}{l}\text { Youth } \\
\text { Mobility }\end{array}$ & $\begin{array}{l}\text { Very limited in most } \\
\text { countries }\end{array}$ & $\begin{array}{l}\text { Substantial programme, } \\
\text { capped }\end{array}$ & $\begin{array}{l}\text { Very large programme, } \\
\text { allows status change and } \\
\text { feeds temporary work }\end{array}$ & $\begin{array}{l}\text { Large programme, } \\
\text { allows status change and } \\
\text { feeds temporary work }\end{array}$ & $\begin{array}{l}\text { Very large programme, } \\
\text { allows status change and } \\
\text { feeds temporary work }\end{array}$ & $\begin{array}{l}\text { Modest programme, no } \\
\text { status change allowed }\end{array}$ \\
\hline $\begin{array}{l}\text { Intra- } \\
\text { Corporate } \\
\text { transfers }\end{array}$ & $\begin{array}{l}\text { Variable, conditioned by } \\
\text { the ICT Directive (in } \\
\text { transposition) }\end{array}$ & $\begin{array}{l}\text { Large numbers, } \\
\text { uncapped, restrictions on } \\
\text { status change }\end{array}$ & $\begin{array}{l}\text { Allowed to switch into } \\
\text { permanent residence for } \\
\text { employment }\end{array}$ & $\begin{array}{l}\text { Allowed to switch into } \\
\text { permanent residence for } \\
\text { employment }\end{array}$ & $\begin{array}{l}\text { Allowed to switch into } \\
\text { permanent residence for } \\
\text { employment }\end{array}$ & $\begin{array}{l}\text { Allowed to switch into } \\
\text { permanent residence for } \\
\text { employment }\end{array}$ \\
\hline Fee policy & $\begin{array}{l}\text { Generally nominal, but } \\
\text { wide range }\end{array}$ & High & High & High & High & High \\
\hline
\end{tabular}


Table A.3. Examples of Qualification Requirements under Blue Card schemes

\begin{tabular}{|c|c|c|c|}
\hline Country & Attestation of evidence of higher education qualifications & Attestation of experience & Regulated Professions \\
\hline Austria & $\begin{array}{l}\text { In case of doubt or if the diploma is not included in the German } \\
\text { "Anabin" database, it can be assessed by the ENIC NARIC. Recognition } \\
\text { requires: certificate of graduation; proof of the status of the } \\
\text { university or other tertiary education institution. All documents have } \\
\text { to be submitted in the original, legalised and with a legalised German } \\
\text { translation. AMS examines whether the requirements are met. The } \\
\text { procedure is identical for the Blue Card and for the Red-White-Red } \\
\text { Card. }\end{array}$ & n.a. & $\begin{array}{l}\text { The competent federal authority decides if the } \\
\text { degree is comparable to the Austrian degree. The } \\
\text { Länder decide whether one can have access to the } \\
\text { regulated labour market. The process can last up } \\
\text { to } 4 \text { months and cost about } 400 \text { euros, depending } \\
\text { on the profession and procedures. }\end{array}$ \\
\hline Belgium & $\begin{array}{l}\text { Employer needs to submit a copy of the degree/certificate. If } \\
\text { necessary it has to be translated by a sworn translator and be } \\
\text { legalized by the country of origin and then by the competent Belgian } \\
\text { embassy or consulate. The regional economic migration offices are } \\
\text { responsible to evaluate these documents (free of cost) within } 30 \text { days } \\
\text { (for receiving the preliminary work permit, after which one can apply } \\
\text { for a Blue Card). The requirements are the same for the regular work } \\
\text { permit B. }\end{array}$ & n.a. & $\begin{array}{l}\text { Access to regulated professions is a competence } \\
\text { of the regions since 2014. The requirements are } \\
\text { different for different professions, and can } \\
\text { sometimes be very cumbersome. }\end{array}$ \\
\hline Bulgaria & $\begin{array}{l}\text { The responsible body I the National NARIC centre. Documents issued } \\
\text { by educational institutions should be certified by: the Ministry of } \\
\text { Foreign Affairs or Consular departments in the issuing country. } \\
\text { Documents such as declarations, powers of attorney, etc., after } \\
\text { certification by a notary in the foreign country must be certified for } \\
\text { authenticity. In addition a certified translation is required. }\end{array}$ & $\begin{array}{l}\text { Requirements are strict but vary. } \\
\text { Different documents are accepted (e.g., } \\
\text { work record and record of the social } \\
\text { security for the same period). }\end{array}$ & $\begin{array}{l}\text { There is no common e-system between NARIC and } \\
\text { the educational system, and delays can be long. }\end{array}$ \\
\hline
\end{tabular}


DELSA/ELSA/WD/SEM(2016)6

\begin{tabular}{|c|c|c|c|}
\hline France & $\begin{array}{l}\text { The responsible agency for recognition of foreign qualifications is } \\
\text { CIEP (Centre international d'études pédagogiques) - ENIC-NARIC } \\
\text { centre. Required documents include: sworn translation of the } \\
\text { qualification certificate; sworn translation of proof of the official } \\
\text { duration of the studies leading to the qualification(s), or an official } \\
\text { translation from the authorities in the country of issue. Must explain } \\
\text { reason for request (looking for a job, enrolling at a training } \\
\text { institution, etc.); Experts conduct specific research for each file } \\
\text { submitted. }\end{array}$ & $\begin{array}{l}\text { Previous experience has to be certified } \\
\text { through attestations by former } \\
\text { employers. }\end{array}$ & $\begin{array}{l}\text { Competent authorities and administrative steps } \\
\text { and requirements depend on the qualification and } \\
\text { profession in question. }\end{array}$ \\
\hline Italy & $\begin{array}{l}\text { The declaration of value from the consular authorities is considered } \\
\text { sufficient. This change significantly lowered the barrier to uptake of } \\
\text { the Blue Card. }\end{array}$ & $\begin{array}{llr}\text { Professional } & \text { experience } & \text { must be } \\
\text { recognised } & \text { only for } & \text { regulated } \\
\text { professions. } & & \end{array}$ & $\begin{array}{l}\text { For professions not covered by Directive } \\
2005 / 36 / E C \text {, there is a requirement of } 2 \text { years } \\
\text { practice in the prior } 10 \text { years. Bodies in individual } \\
\text { Italian regions are responsible. If the degree has } \\
\text { not been previously recognised in another case, } \\
\text { the competent Ministry holds a panel of } \\
\text { representatives (from professional associations, } \\
\text { the Ministry of Foreign Affairs, and local } \\
\text { authorities) to decide. Panels also apply to all } \\
\text { health professions and architecture. }\end{array}$ \\
\hline Lithuania & $\begin{array}{l}\text { The Centre for Quality Assessment in Higher Education is the } \\
\text { responsible authority. Requires diploma, academic transcript, and } \\
\text { other documents proving the qualification. Sworn translations must } \\
\text { be provided of documents not in Lithuanian, Russian or English. The } \\
\text { documents must be either originals or certified copies. Documents } \\
\text { must be legalised or certified with the apostille, unless the } \\
\text { documents are issued by EU, USA, Russia, Belarus, Moldova or } \\
\text { Ukraine. }\end{array}$ & $\begin{array}{l}\text { Only a theoretical possibility since no } \\
\text { professional experience is considered as } \\
\text { equivalent to high education according } \\
\text { to national law. }\end{array}$ & $\begin{array}{l}\text { Qualification must be recognised by a different } \\
\text { competent authority depending on profession, } \\
\text { each with its own recognition rules. } \\
\text { Requirements: the applicant must submit the } \\
\text { necessary documents translated into Lithuanian, } \\
\text { in some cases legalised (or certified by apostille). }\end{array}$ \\
\hline Luxembourg & $\begin{array}{l}\text { The applicant must present an attestation which certifies that } s / \text { he } \\
\text { has the professional qualifications required for the activity or sector } \\
\text { mentioned in the labour contract. The diplomas have to be translated } \\
\text { to French, German or English by an official translator. The legalisation } \\
\text { or authentication of documents is only required in case there is a } \\
\text { doubt on the validity of the documents. }\end{array}$ & $\begin{array}{l}\text { Professional experience is defined as the } \\
\text { actual and lawful pursuit of the } \\
\text { profession. The applicant has to present } \\
\text { a document attesting the high } \\
\text { professional qualifications relevant to } \\
\text { the activity or sector specified in the } \\
\text { work contract. }\end{array}$ & $\begin{array}{l}\text { The applicant must present an attestation which } \\
\text { certifies that } s / \text { he satisfies the required conditions } \\
\text { for the exercise of the regulated profession } \\
\text { mentioned in the labour contract. Recognition is } \\
\text { as for other cases. }\end{array}$ \\
\hline
\end{tabular}


DELSA/ELSA/WD/SEM(2016)6

\begin{tabular}{|c|c|c|c|}
\hline Netherlands & $\begin{array}{l}\text { For recognition of professional qualification, Centres of Expertise for } \\
\text { International Credential Evaluation (Nuffic ) and SBB (the Foundation } \\
\text { for Cooperation on Vocational Education, Training and the Labour } \\
\text { Market) issue written statements on the recognition, and the } \\
\text { Information Centre for Credential Evaluation (IcDW) acting as a } \\
\text { central desk for application. Requires sworn translation of diploma } \\
\text { and transcript, unless the original documents are in Dutch, English, } \\
\text { German, French or Afrikaans. }\end{array}$ & n.a. & $\begin{array}{l}\text { One needs a permission to practise it in the } \\
\text { Netherlands. A specific institution has to be } \\
\text { consulted for each of the enlisted professions in } \\
\text { order to obtain information and conditions of this } \\
\text { recognition. }\end{array}$ \\
\hline Portugal & Competent authority is the Immigration Authorities & $\begin{array}{l}\text { Competent authority is the Immigration } \\
\text { Authorities }\end{array}$ & $\begin{array}{l}\text { Competent body varies. Procedure can be very } \\
\text { difficult and long, according to the body. }\end{array}$ \\
\hline Romania & $\begin{array}{l}\text { Competent authority is in general the National Centre for Recognition } \\
\text { and Validation of Diplomas (CNRED), under the Ministry of Education } \\
\text { (however other authorities can be relevant depending on residence } \\
\text { permit). Recognition follows the regular procedure provided by the } \\
\text { national legislation. The specialized institution for recognition of } \\
\text { qualification diplomas issued by providers of vocational training } \\
\text { abroad (which are not accredited schools or education institution) is } \\
\text { the National Authority for Qualification. }\end{array}$ & n.a. & $\begin{array}{l}\text { Competent authority varies depending on } \\
\text { profession. The access to a regulated profession is } \\
\text { subordinated to the fulfilment of specific } \\
\text { conditions provided by the special laws. }\end{array}$ \\
\hline Spain & Generally university recognition procedure (long) & Not clarified in legislation. & $\begin{array}{l}\text { It requires complex procedures and is very slow. } \\
\text { Many approvals take one to two years to be } \\
\text { processed. }\end{array}$ \\
\hline Sweden & $\begin{array}{l}\text { The Swedish Council for Higher Education (UHR) is responsible for the } \\
\text { recognition of foreign qualifications. Requires a stamped or otherwise } \\
\text { institutionally certified copy and authorised translation of the degree } \\
\text { certificate/diploma and official transcript, and proof of application for } \\
\text { a residence permit. }\end{array}$ & $\begin{array}{l}\text { Employer decides. The Migration Board } \\
\text { assesses if the qualifications can lay the } \\
\text { basis for granting the permit. }\end{array}$ & $\begin{array}{l}\text { Issues on recognition of qualifications for } \\
\text { regulated professions are assessed by the } \\
\text { competent authority. }\end{array}$ \\
\hline
\end{tabular}




\section{Table A.4. Labour market mobility for EU Blue Card holders}

\begin{tabular}{|c|c|c|}
\hline Country & Modifications require prior notification or prior approval? & Allows labour market mobility after two years \\
\hline Austria & $\begin{array}{l}\text { The employer shall communicate to the regional office of the AMS } \\
\text { within three days the beginning and the end of the employment of a } \\
\text { foreigner }\end{array}$ & $\begin{array}{l}\text { BC holder can be granted a "RWR card plus", if they hold a Blue } \\
\text { Card for two years. This give total mobility. }\end{array}$ \\
\hline Belgium & $\begin{array}{l}\text { Any change of the employer as well as any change in the conditions of } \\
\text { employment which affects the validity of the Blue Card is subject to } \\
\text { the prior issuing by the competent authority of a provisional work } \\
\text { permit. }\end{array}$ & $\begin{array}{l}\text { The } \mathrm{BC} \text { holder has to notify the changes to the Minister or his } \\
\text { representative. The competent authority notifies the Immigration } \\
\text { Department of any information provided by the employer with } \\
\text { regard to the termination of employment or in connection with } \\
\text { changes on employment conditions. }\end{array}$ \\
\hline Bulgaria & $\begin{array}{l}\text { The } \mathrm{BC} \text { holder can change employer only after receiving written } \\
\text { permission from the Employment Agency }\end{array}$ & Continued restrictions \\
\hline Czech Republic & $\begin{array}{l}\text { Blue Card holder is obliged to communicate above mentioned changes } \\
\text { to the Ministry within a time limit of three working days. }\end{array}$ & Same as in initial period. \\
\hline Estonia & $\begin{array}{l}\text { Estonian Unemployment Insurance Fund must consent in case of new } \\
\text { employment and employer. }\end{array}$ & Yes. \\
\hline Greece & Requires prior written approval from the competent authority. & Requires only communication of change. \\
\hline Spain & Renewal of the authorisation must be requested. & $\begin{array}{l}\text { Employer must communicate the employment contract to the } \\
\text { Public Employment Services. }\end{array}$ \\
\hline Finland & $\begin{array}{l}\text { Holder may work in one or several professional fields. For special } \\
\text { reasons, s/he may be restricted to work for a certain employer. }\end{array}$ & Same as in first period \\
\hline France & Requires prior written approval from the competent authority. & Yes. \\
\hline
\end{tabular}




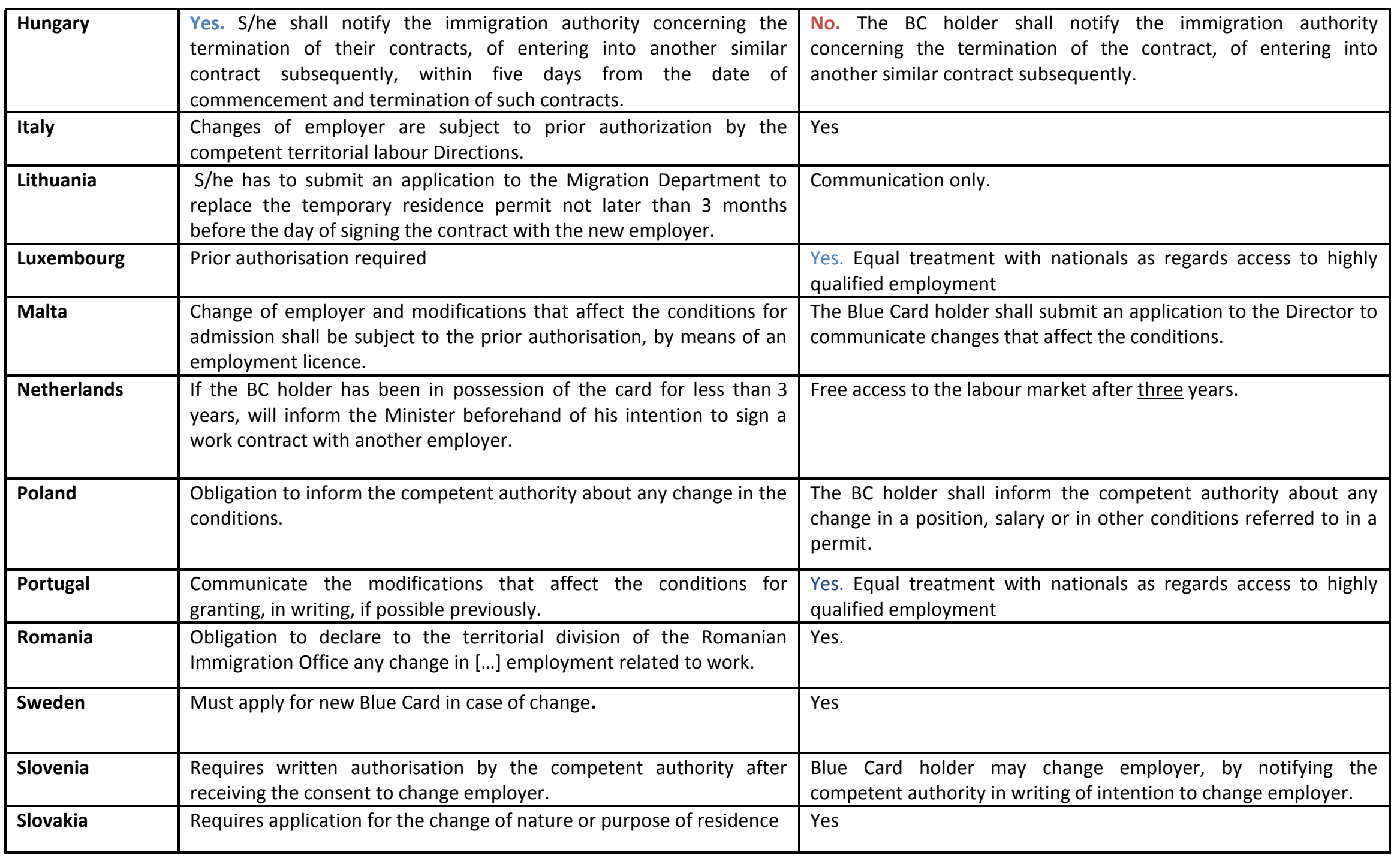


Figure A.1. Salary distribution in selected EU countries, tertiary educated full-time employees

Blue: national Blue Card thresholds; Red: median; Green: mean

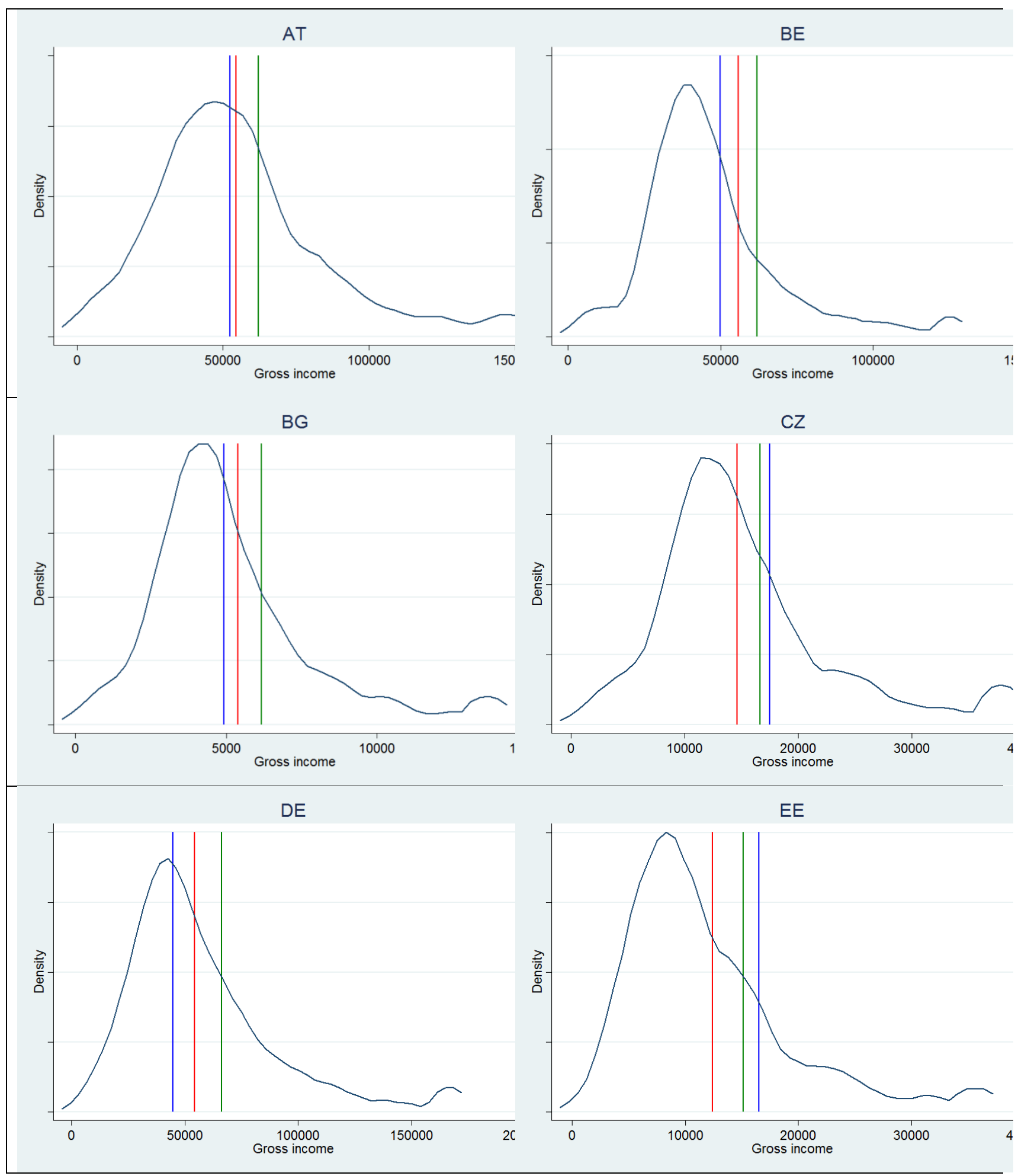




\section{DELSA/ELSA/WD/SEM(2016)6}

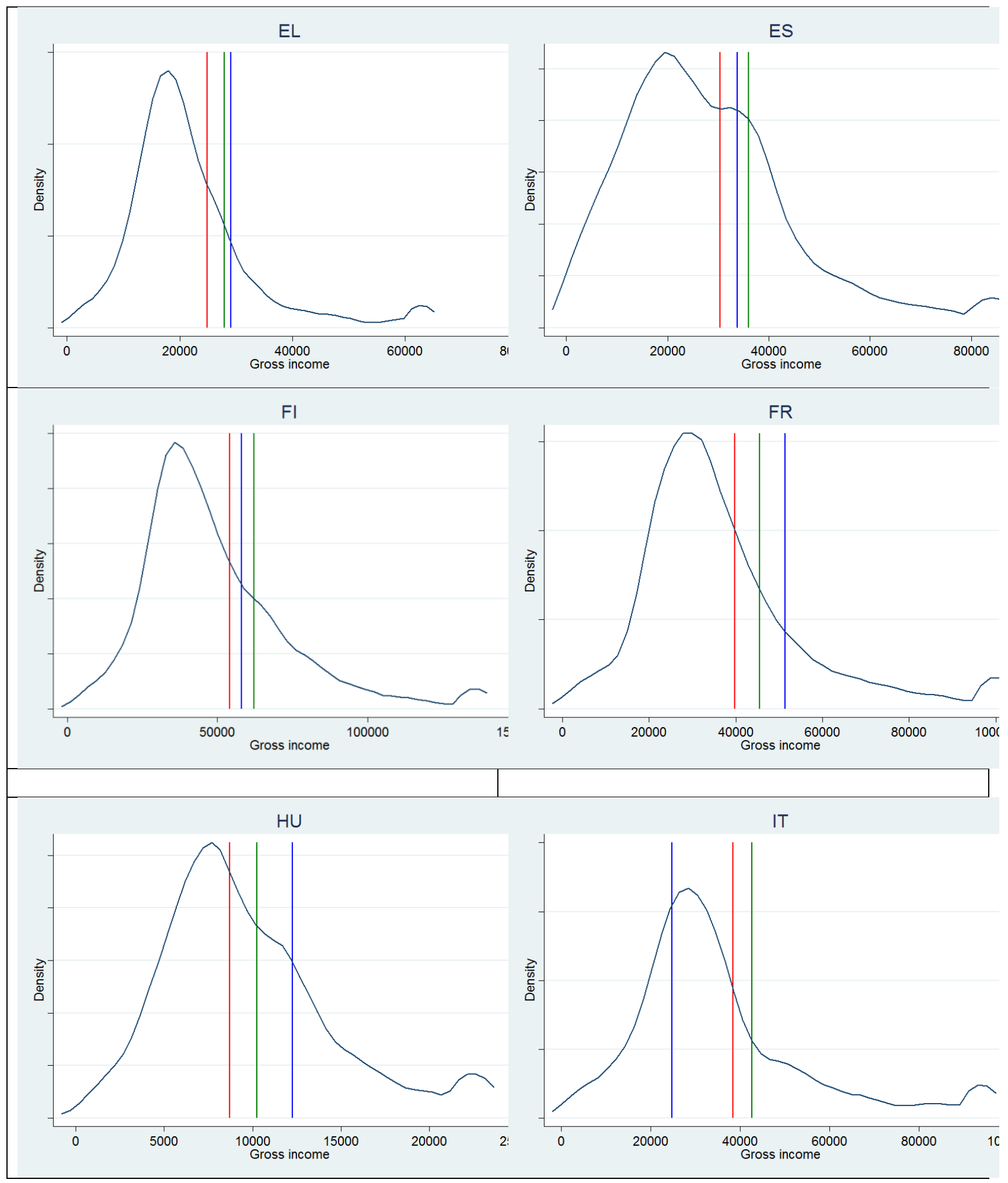


DELSA/ELSA/WD/SEM(2016)6

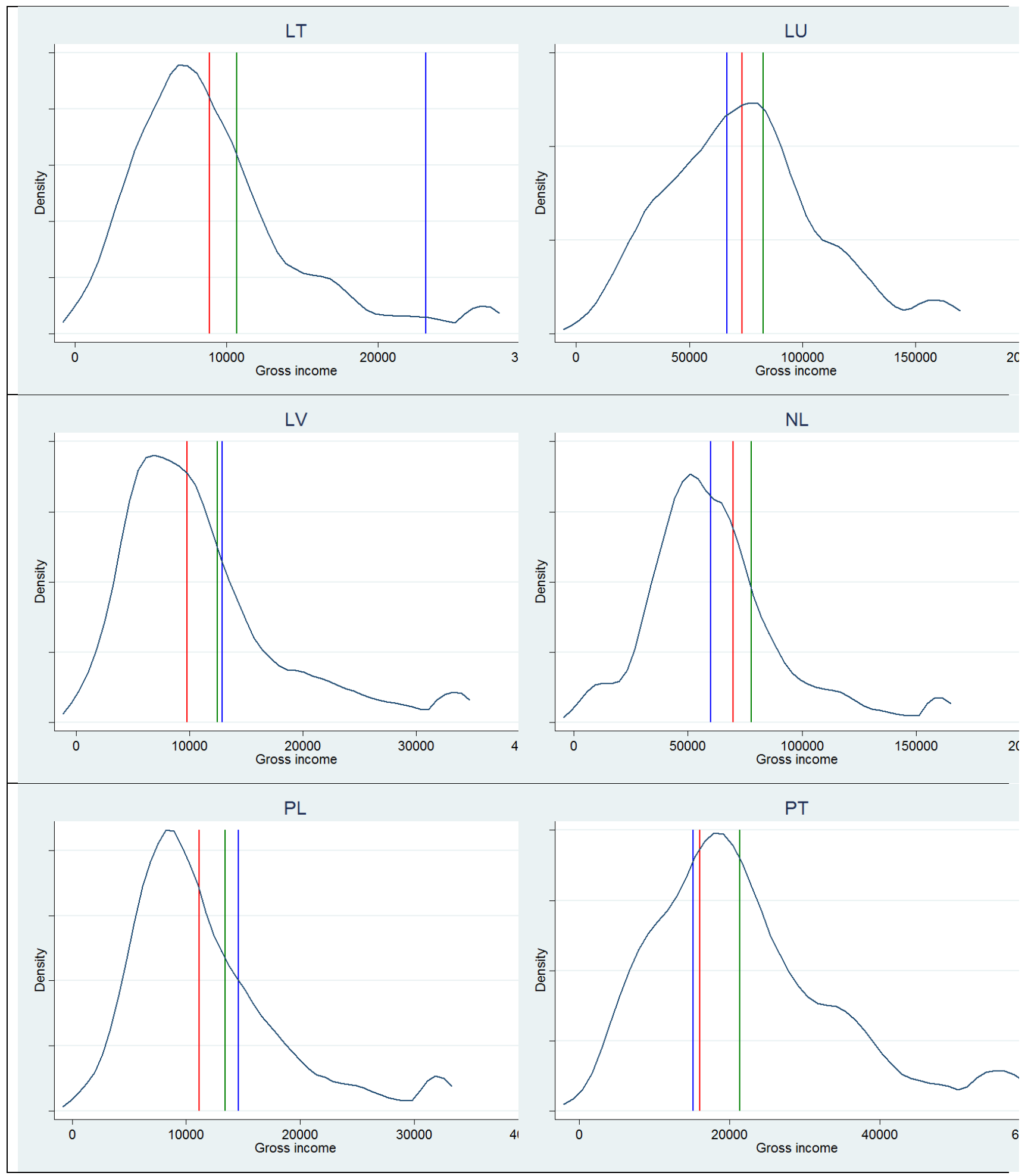




\section{DELSA/ELSA/WD/SEM(2016)6}
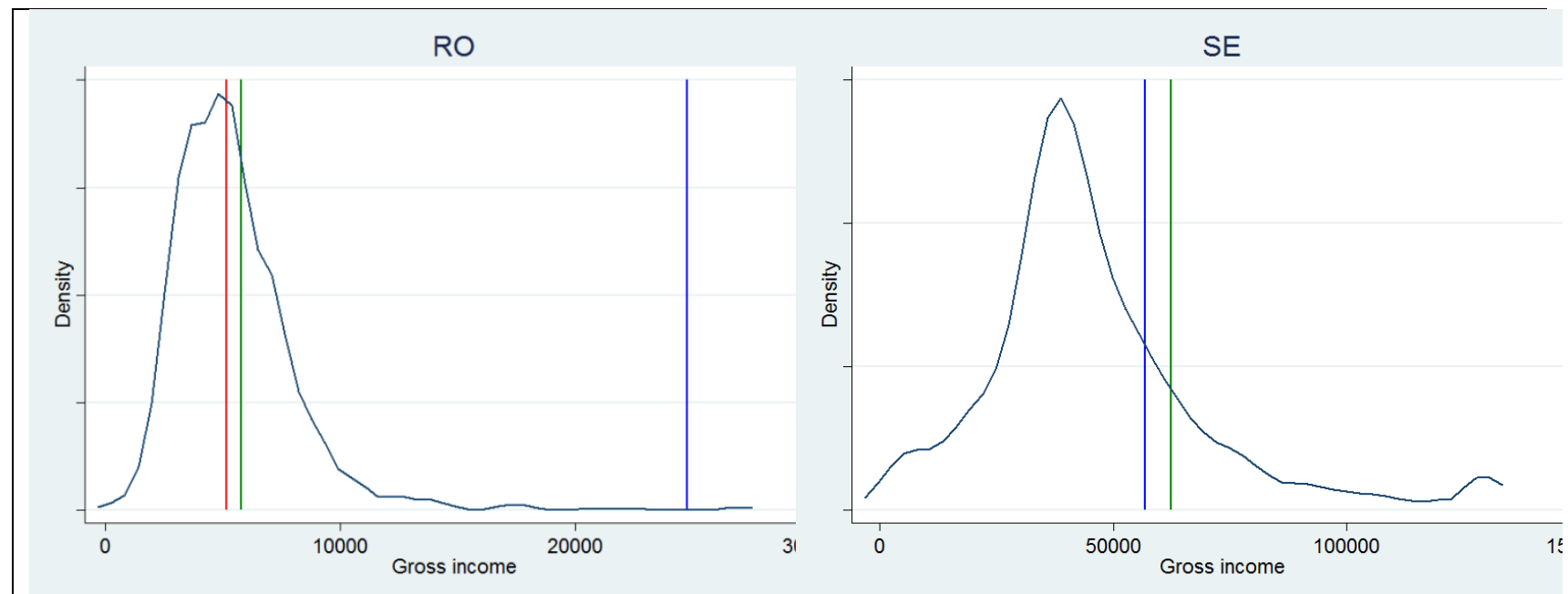

SI

SK
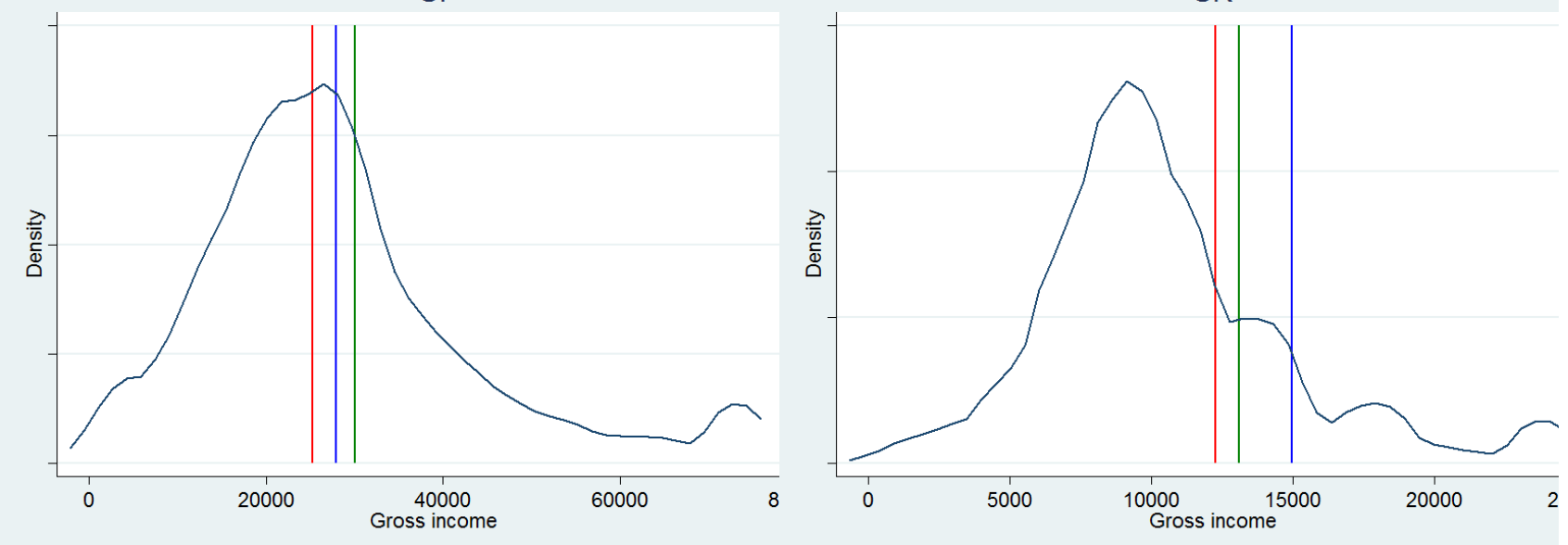

Source: EU SILC 
Figure A.2. Salary distribution in non-Blue Card EU countries, tertiary educated full-time employees

Dotted Blue: national thresholds; Red: median; Green: mean

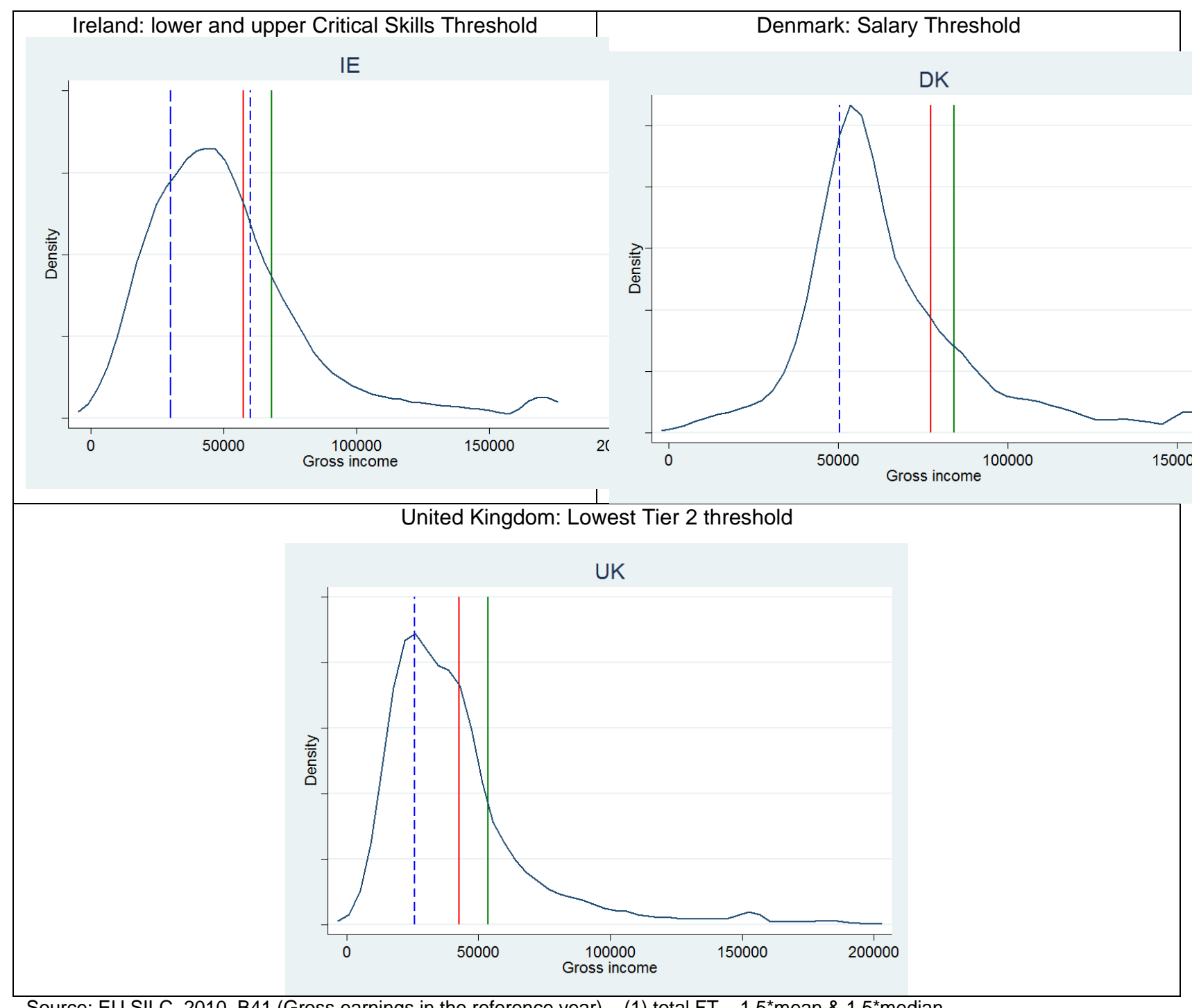

Source: EU SILC, 2010. B41 (Gross earnings in the reference year) _ (1) total FT _ $1.5^{\star}$ mean \& $1.5^{\star}$ median 
Figure A.3. Salary distribution in selected EU countries, tertiary educated full-time employees age 25-30

Blue: national Blue Card thresholds; Red: median; Green: mean
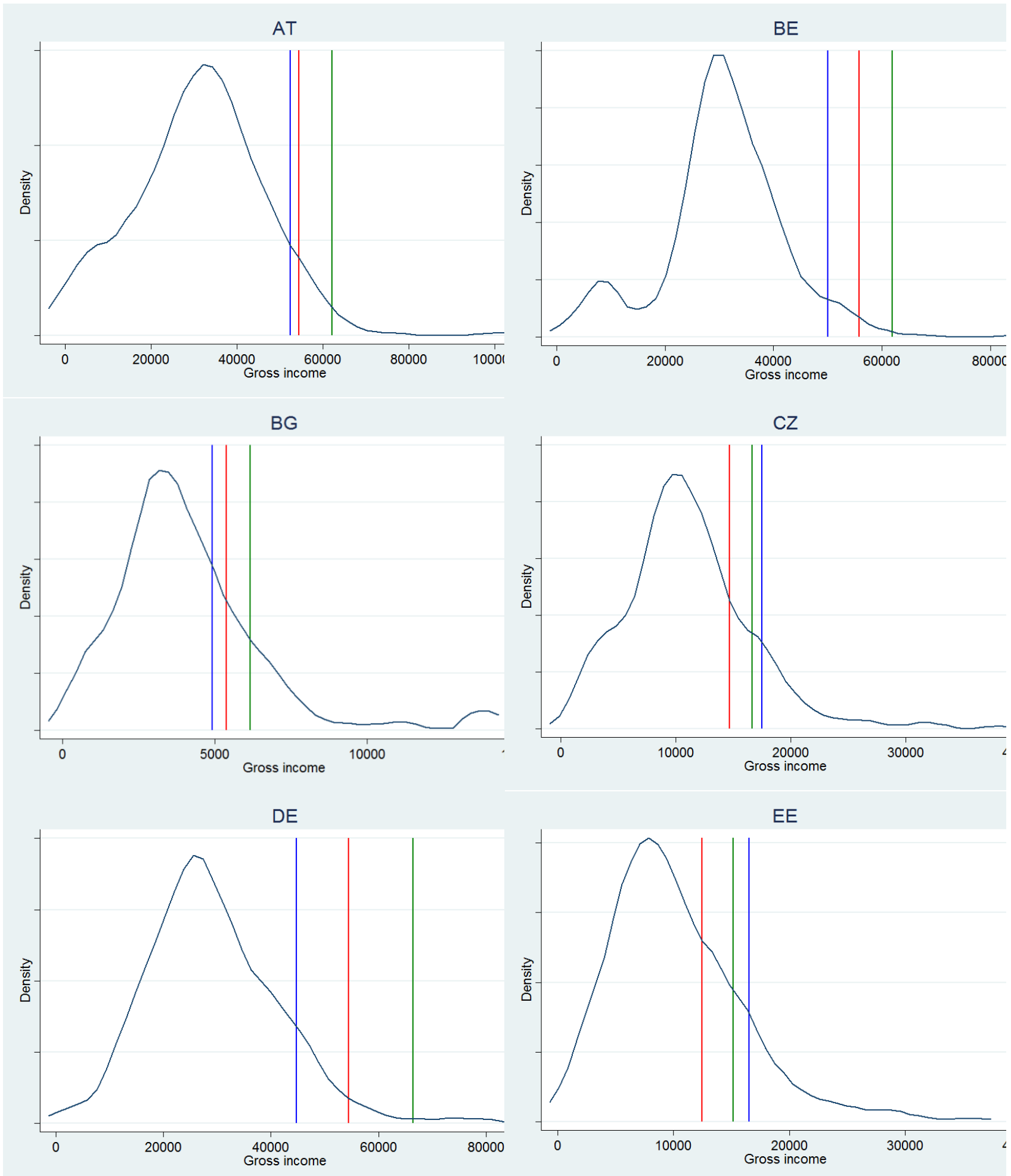
DELSA/ELSA/WD/SEM(2016)6
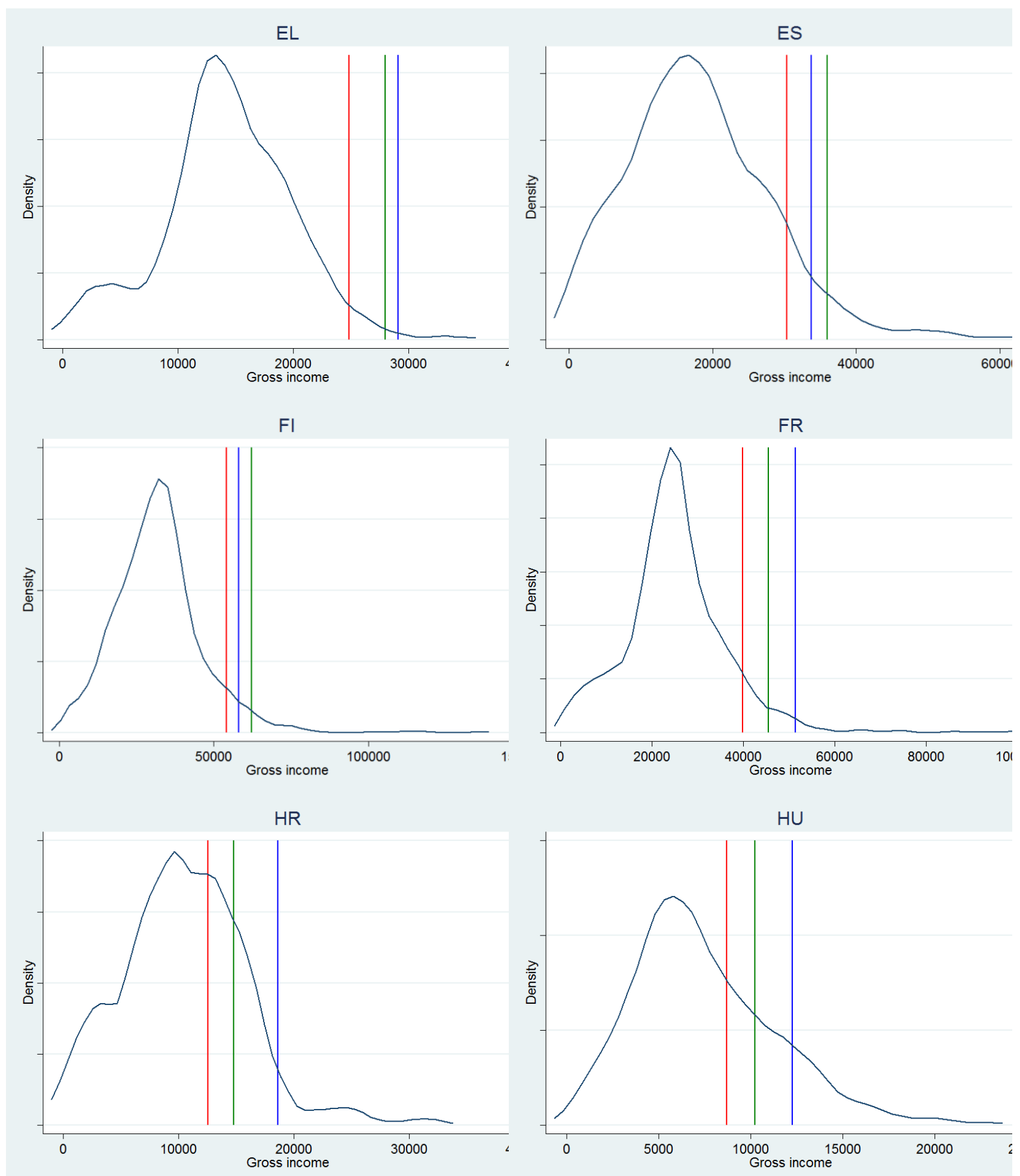


\section{DELSA/ELSA/WD/SEM(2016)6}
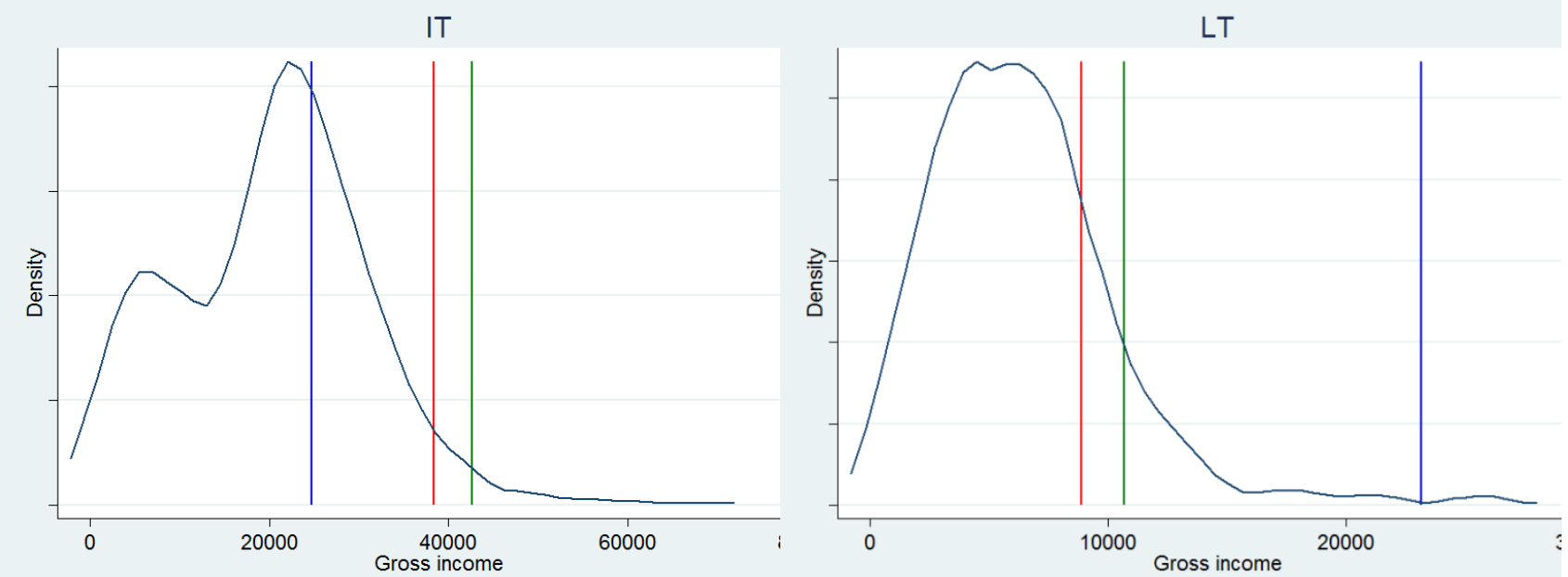

LU

LV
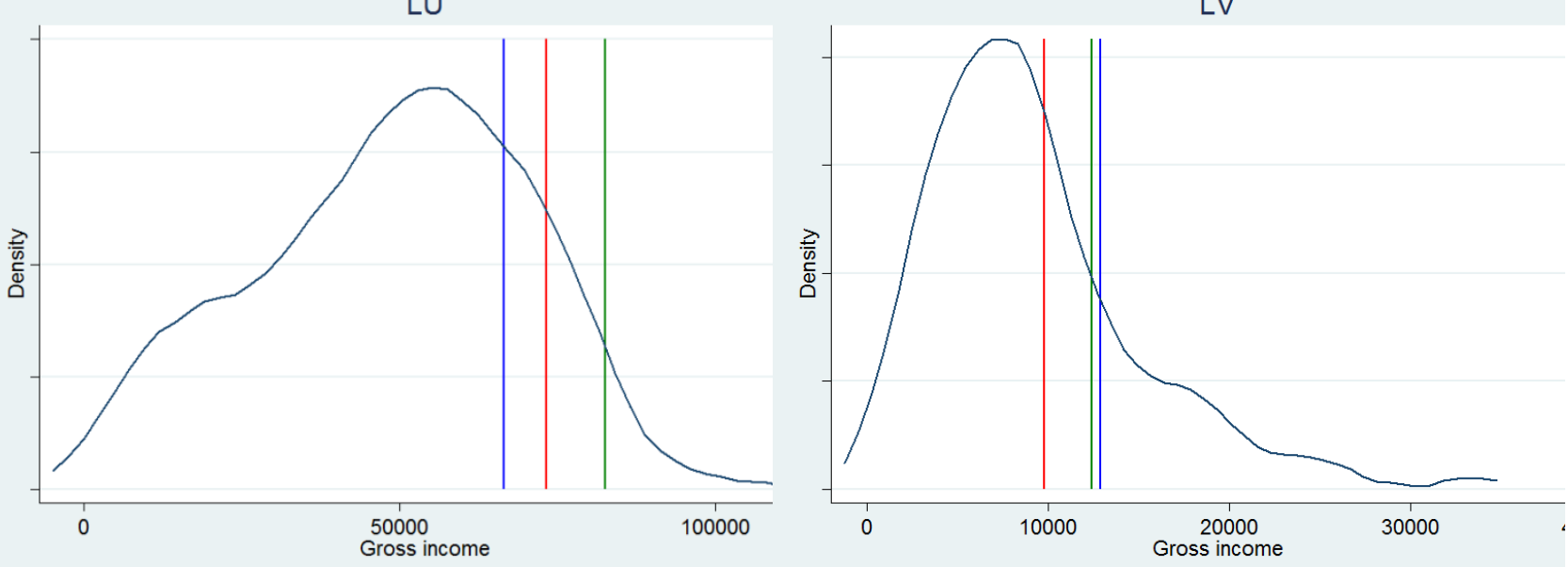

MT

NL
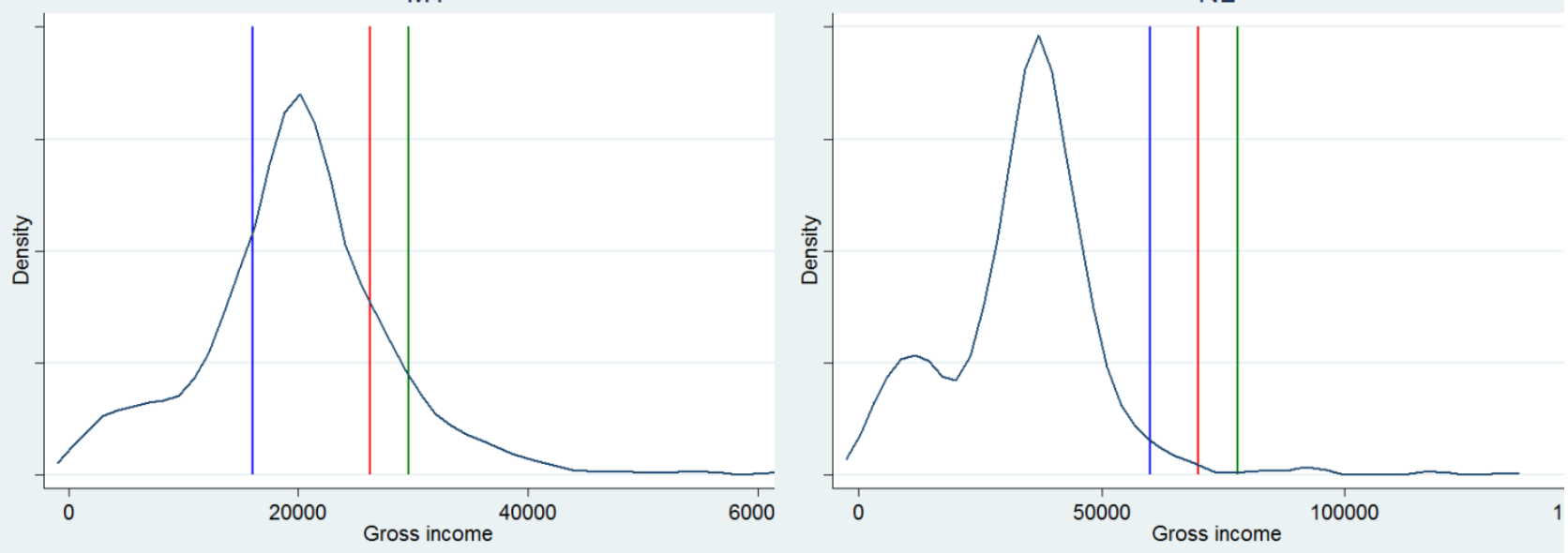
DELSA/ELSA/WD/SEM(2016)6

PL

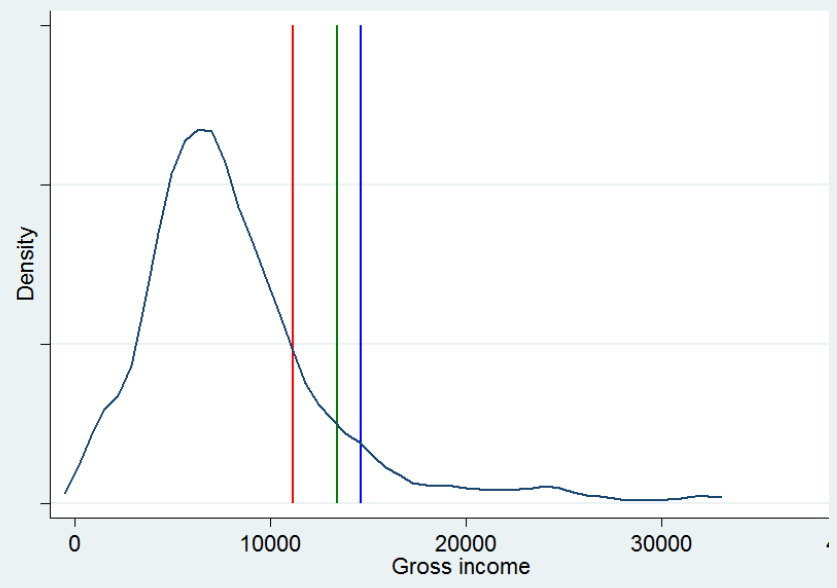

RO

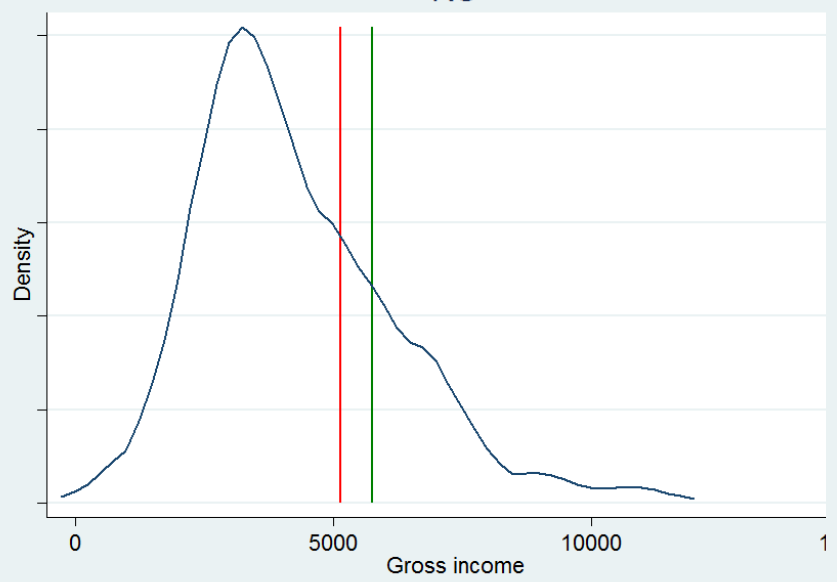

SI

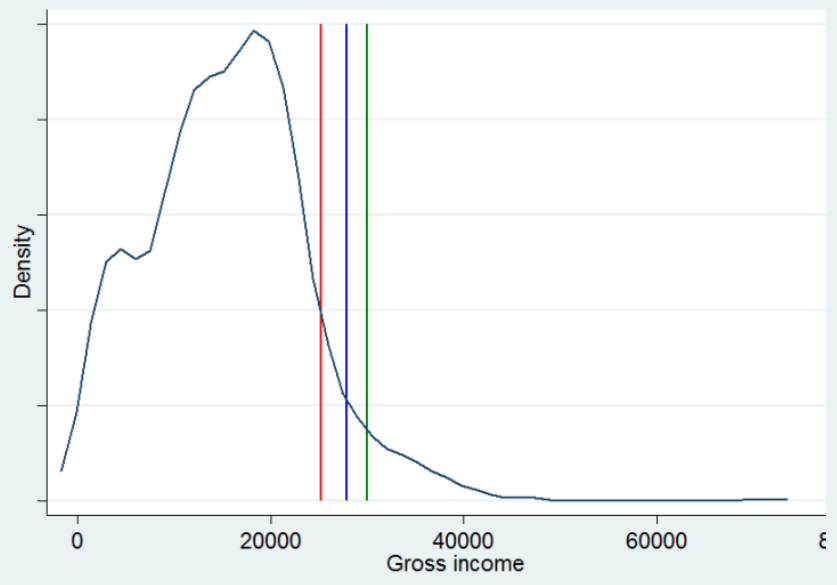

PT

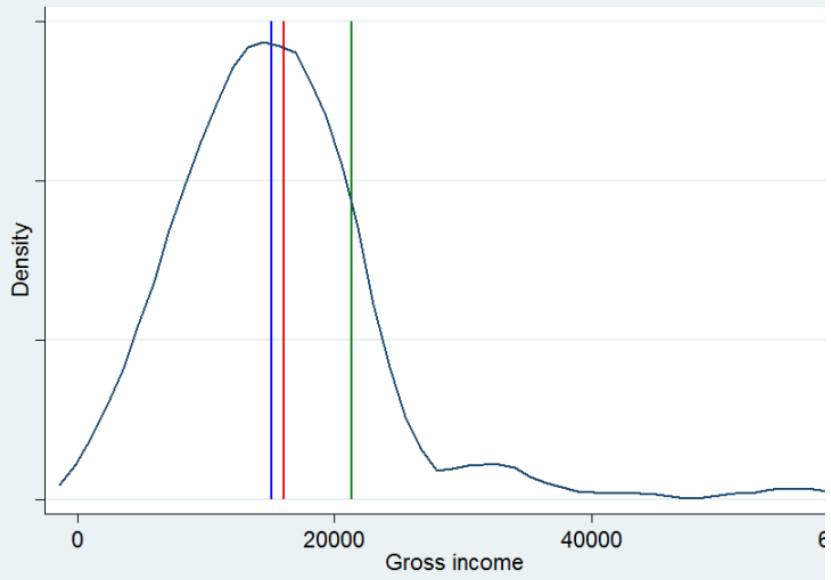

SE

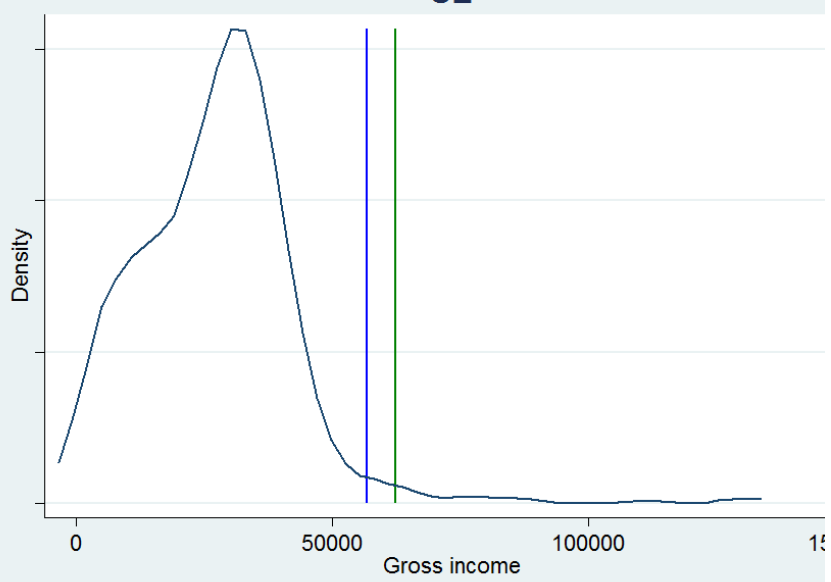

SK

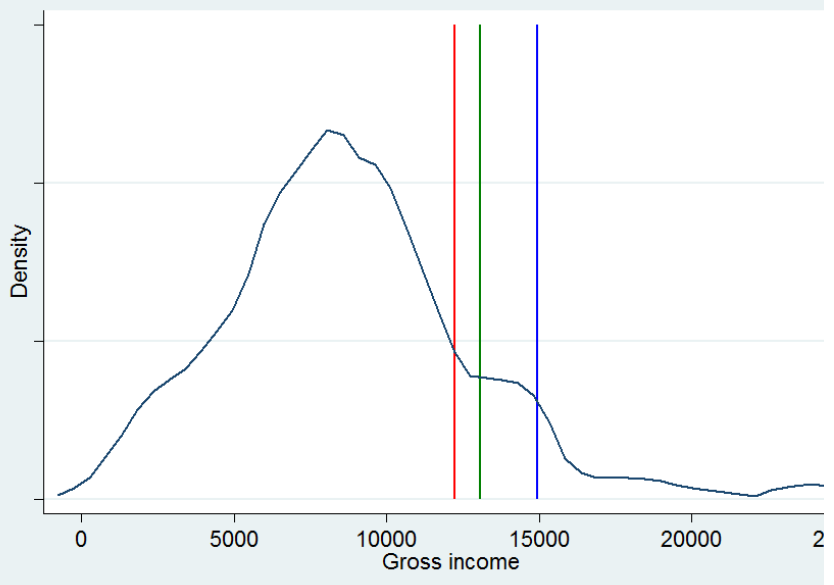


Figure A.4. Salary distribution in selected EU countries, tertiary educated full-time employees age 25-30 Dotted Blue: national thresholds; Red: median; Green: mean

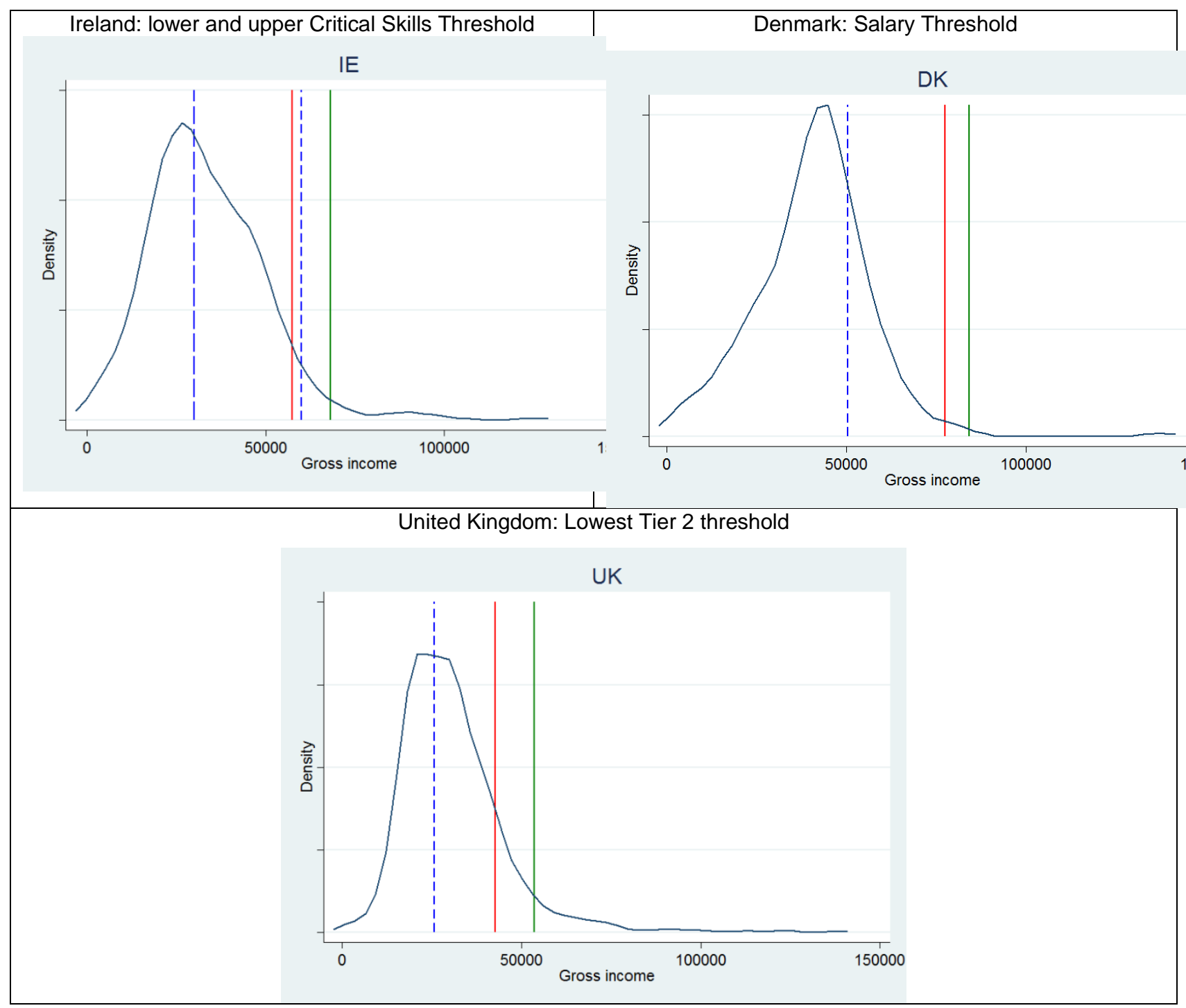

